\title{
Evolution of Asian aerosols during transpacific transport in INTEX-B
}

\author{
E. J. Dunlea ${ }^{1}$, P. F. DeCarlo ${ }^{1,2, *}$, A. C. Aiken ${ }^{1,3}$, J. R. Kimmel ${ }^{1}$, R. E. Peltier ${ }^{4, * *}$, R. J. Weber ${ }^{4}$, J. Tomlinson ${ }^{5, * * *}$, \\ D. R. Collins ${ }^{5}$, Y. Shinozuka ${ }^{6}$, C. S. McNaughton ${ }^{6}$, S. G. Howell ${ }^{6}$, A. D. Clarke ${ }^{6}$, L. K. Emmons ${ }^{7}$, E. C. Apel ${ }^{7}$, \\ G. G. Pfister ${ }^{7}$, A. van Donkelaar ${ }^{8}$, R. V. Martin ${ }^{8,9}$, D. B. Millet ${ }^{10}$, C. L. Heald ${ }^{11, * * * *}$, and J. L. Jimenez ${ }^{1,3}$ \\ ${ }^{1}$ Cooperative Institute for Research in Environmental Sciences (CIRES), University of Colorado, Boulder, \\ CO 80309-0216, USA \\ ${ }^{2}$ Department of Atmospheric and Oceanic Science, University of Colorado, Boulder, CO 80309-0311, USA \\ ${ }^{3}$ Department of Chemistry and Biochemistry, University of Colorado, Boulder, CO 80309-0215, USA \\ ${ }^{4}$ School of Earth and Atmospheric Sciences, Georgia Institute of Technology, Atlanta, GA, USA \\ ${ }^{5}$ Department of Atmospheric Sciences, Texas A\&M University, College Station, TX 77843, USA \\ ${ }^{6}$ Department of Oceanography, University of Hawaii, Honolulu, HI, USA \\ ${ }^{7}$ National Center for Atmospheric Research, P.O. Box 3000, Boulder, CO 80307-3000, USA \\ ${ }^{8}$ Department of Physics and Atmospheric Science, Dalhousie University Halifax, NS B3H 3J5, Canada \\ ${ }^{9}$ Harvard-Smithsonian Center for Astrophysics, Cambridge, MA, 02138, USA \\ ${ }^{10}$ Department of Soil, Water, and Climate, University of Minnesota, St. Paul, MN 55108, USA \\ ${ }^{11}$ Department of Chemistry, University of California - Berkeley, Berkeley, CA, 94720, USA \\ *now at: Paul Scherrer Institute, 5232 Villigen-PSI, Switzerland \\ ** now at: NYU School of Medicine, Tuxedo, NY 10987, USA \\ *** now at: Pacific Northwest National Laboratory, Richland, WA 99352, USA \\ ${ }^{* * * * *}$ now at: Department of Atmospheric Science, Colorado State University, Fort Collins, CO 80523, USA
}

Received: 9 July 2008 - Published in Atmos. Chem. Phys. Discuss.: 14 August 2008

Revised: 10 September 2009 - Accepted: 10 September 2009 - Published: 1 October 2009

\begin{abstract}
Measurements of aerosol composition were made with an Aerodyne High Resolution Time-of-Flight Aerosol Mass Spectrometer (HR-ToF-AMS) on board the NSF/NCAR C-130 aircraft as part of the Intercontinental Chemical Transport Experiment Phase B (INTEX-B) field campaign over the Eastern Pacific Ocean. The HR-ToF-AMS measurements of non-refractory submicron aerosol mass are shown to compare well with other aerosol instrumentation in the INTEX-B field study. Two case studies are described for pollution layers transported across the Pacific from the Asian continent, intercepted 3-4 days and 7-10 days downwind of Asia, respectively. Aerosol chemistry is shown to be a robust tracer for air masses originating in Asia, specifically the presence of sulfate dominated aerosol is a distinguishing feature of Asian pollution layers that have been transported to the Eastern Pacific. We examine the time scales of processing for sulfate and organic aerosol in the
\end{abstract}

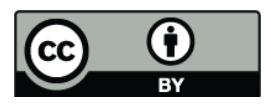

Correspondence to: E. Dunlea

(edward.dunlea@colorado.edu) atmosphere and show that our observations confirm a conceptual model for transpacific transport from Asia proposed by Brock et al. (2004). Our observations of both sulfate and organic aerosol in aged Asian pollution layers are consistent with fast formation near the Asian continent, followed by washout during lofting and subsequent transformation during transport across the Pacific. Our observations are the first atmospheric measurements to indicate that although secondary organic aerosol (SOA) formation from pollution happens on the timescale of one day, the oxidation of organic aerosol continues at longer timescales in the atmosphere. Comparisons with chemical transport models of data from the entire campaign reveal an under-prediction of organic aerosol mass in the MOZART model, but much smaller discrepancies with the GEOS-Chem model than found in previous studies over the Western Pacific. No evidence is found to support a previous hypothesis for significant secondary organic aerosol formation in the free troposphere.

Published by Copernicus Publications on behalf of the European Geosciences Union. 


\section{Introduction}

Aerosols play important roles in atmospheric processes that affect global climate change (IPCC, 2007), stratospheric ozone depletion (Solomon, 1999), regional visibility (Watson, 2002), human health (Pope et al., 2002; Pope, 2000; Schwartz, 1994), and ecological integrity via acid, toxic, and nutrient deposition (Bytnerowicz et al., 1996; Schindler, 1988, 1999). Emissions of pollutants, including aerosols, from Asia are significant on a global scale; they have increased dramatically in the past two decades and will likely continue to increase in the coming decades (Ohara et al., 2007). For this study, the term "Asian" generally refers to emissions that originated in China/East Asia. Changes in Asian emissions are already reflected in increased sulfate aerosol concentrations over the Pacific Ocean, which has large implications for future climate change (Prospero et al., 2003). Long range transport of aerosols is an important issue for climate, and the International Global Atmospheric Chemistry (IGAC) Intercontinental Transport and Chemical Transformation (ITCT) series of campaigns was designed to study long-range transport in various regions of the world (http: //www.igac.noaa.gov/ITCT.php). As part of IGAC-ITCT, the Intercontinental Chemical Transport Experiment - Phase B (INTEX-B) field campaign focused on in-situ measurements from aircraft and ground sites of transported Asian pollution over the Eastern Pacific and west coast of North America (Singh et al., 2009). The campaign involved several research airplanes, including the NSF/NCAR C-130 (referred to as "C-130" hereafter), the NASA DC-8, and the Canadian Cessna 207. The INTEX-B Pacific portion of the campaign immediately followed the Megacity Initiative: Local and Global Research Observations (MILAGRO) campaign, which focused on the outflow from Mexico City (DeCarlo et al., 2008; Molina et al., 2008), and the payload for the C-130 remained essentially the same between the two campaigns. The Pacific portion of INTEX-B took place from 17 April to 15 May 2006, with the intention of capturing the spring time maximum in transpacific transport from Asia to North America (Singh et al., 2009).

Of the various pathways for air masses transported out of Asia, those that extend out over the Pacific towards North America at mid-latitudes are largely determined by cyclones, along with the westerly zonal wind, and seasonal convection processes (Wuebbles et al., 2007). Long-range transport in this direction is driven by the persistent mid-latitude westerlies that result in intercontinental transport of Asian air masses from west to east. The high speed winds in the upper troposphere make the rapid transport of pollutants possible. A key aspect of long-range transport is the mechanism for lofting of pollutants into the mid and upper troposphere. Lofting of pollutants in warm conveyer belts (WCB) (Cooper et al., 2004) has been shown to be one of the more important mechanisms for rapid intercontinental pollutant transport (Liang et al., 2004). Much of the anthropogenic aerosol transported across the Pacific is narrowly focused in the lower free troposphere between $900-700 \mathrm{hPa}(1-3 \mathrm{~km})$ (Heald et al., 2006; Uno et al., 2008). Low level transpacific transport, below $2.2 \mathrm{~km}$, does not contribute significantly to air that reaches the west coast of North America (Holzer et al., 2007). There is recent evidence that dry convection behind cold fronts may play a significant role in lofting pollutants over the Asian continent, but that warm conveyer belts are the main mechanism for lofting over the ocean just off the coast of Asia (Dickerson et al., 2007).

Many previous studies have examined transpacific transport of Asian pollution (Berntsen et al., 1999; Chin et al., 2007; Day et al., 2009; Heald et al., 2006; Jacob et al., 1999; Jaffe et al., 1999, 2003; Keating et al., 2005; Liang et al., 2004; Liu et al., 2007, 2008; Parrish et al., 1992; Pfister et al., 2009; Reidmiller et al., 2008, 2009; Stohl et al., 2002; Strode et al., 2008; Wolfe et al., 2007; Yu et al., 2008; Zhang et al., 2008) (also see (Dickerson et al., 2007) and references therein, and for a review see (Wuebbles et al., 2007)). Specifically, several studies have included in-situ measurements over the Eastern Pacific from aircraft (Andreae et al., 1988; Brock et al., 2004; Jaeglé et al., 2003; Nowak et al., 2004; Roberts et al., 2006). It is well established that Asian pollution can reach North America after as little as a few days of transport time with an average transit time of $0.5-2$ weeks (Holzer et al., 2003; Jaffe et al., 2003; Liang et al., 2007; Yienger et al., 2000). Most well-known cases involve the transport of Asian dust, which have caused large visibility problems in various parts of the United States (Husar et al., 2001; McKendry et al., 2001; Tang et al., 2004b; Thulasiraman et al., 2002; Vaughan et al., 2001; Zhao et al., 2008). Long-range transport can significantly impact column values of sulfate (Benkovitz et al., 2006) and the transport of pollution and crustal material from Asia has been speculated to have adverse effects on the marine and terrestrial ecosystems downwind along the transport paths (Cahill, 2003; Duce et al., 1980). However, one of the major scientific needs related to the transport of Asian pollution is a better understanding of the pathways and transformations of the pollutants (Wuebbles et al., 2007). While previous studies have examined the amount of aerosol (Chin et al., 2007; Heald et al., 2006; Liu et al., 2007; van Donkelaar et al., 2008; VanCuren, 2003, 2006) or black carbon (Hadley et al., 2007) that is carried by intercontinental transport to North America, only a few experimental studies have focused on the chemical transformations that Asian pollution undergoes as it is transported across the Pacific as it pertains to aerosol loadings over the Eastern Pacific ocean and North American continent (Brock et al., 2004; Peltier et al., 2008), and there is still much that remains to be understood.

Particles in the accumulation mode (Finlayson-Pitts et al., 2000) (generally less than $1 \mu \mathrm{m}$ in diameter) have the longest lifetime in the atmosphere (days to weeks) and have been implicated with adverse health effects (Pope et al., 2002; Pope, 2000; Schwartz, 1994). Submicron aerosol in the free 
troposphere primarily consists of sulfate and organic material (Murphy et al., 2006). Organic compounds make up a large fraction of submicron aerosol mass at the surface in most Northern Hemisphere mid-latitude locations (Zhang et al., 2007), but there are situations where sulfate is the dominant submicron aerosol component, including downwind of coal-fired power plants (and thus downwind of certain regions within Asia at the surface; Takami et al., 2005; Zhang et al., 2007), downwind of volcanoes (Tu et al., 2004) and in aged Asian pollution observed over the Eastern Pacific (Brock et al., 2004). Until the INTEX-B campaign, this last point has been primarily based on a limited number of observations from the ITCT-2k2 campaign (Brock et al., 2004).

A conceptual model for the transformation of aerosols during transpacific transport was originally proposed by Brock et al. (2004) and discussed further by Peltier et al. (2008). Briefly, as air masses move downwind from Asian source regions, gas phase organic precursors form secondary organic aerosol (SOA) more rapidly than $\mathrm{SO}_{2}$ is converted to sulfate. When a polluted air mass is lifted out of the boundary layer, which often occurs within the first 1-5 days downwind of Asia (most likely in a WCB), the already formed aerosol is washed out during lifting while the less-soluble gas phase compounds such as $\mathrm{SO}_{2}$ are not entirely removed (wet scavenging removal of aerosol has also been discussed by (Lim et al., 2003)). The resulting gas phase mixture is then relatively enhanced in $\mathrm{SO}_{2}$ compared to SOA precursors. Consequently, during the subsequent transpacific transport in the free troposphere, sulfate forms in larger concentrations than SOA. The result is an enhanced sulfate/organic aerosol ratio over the Eastern Pacific.

During the INTEX-B campaign, we were able to intercept more Asian pollution layers than in previous campaigns, spending a significant fraction of the flight time sampling Asian pollution (described below and; Pfister et al., 2009). We examine the time scales of processing for sulfate and organic aerosol in the atmosphere, including the oxidation of organic aerosol, in the context of the conceptual model described above. The INTEX-B campaign also included a larger suite of instruments deployed onboard aircraft than in previous campaigns, including an Aerodyne High Resolution Time-of-Flight Aerosol Mass Spectrometer (HR-ToF-AMS). This paper describes the deployment of the HR-ToF-AMS on board the C-130 (Sect. 2), the observations of aerosol during the INTEX-B campaign (Sect. 3) and the chemical transformation of sulfate and organic aerosols during the transport of Asian aerosol across the Pacific, as well as comparisons of observations with chemical transport models (Sect. 4).

\section{Experimental methods}

This study primarily focuses on data from the C-130 aircraft; during INTEX-B, the C-130 was based at Paine Field in Everett, Washington just outside of Seattle. The
Table 1. Dates for research flights of C-130 during INTEX-B.

\begin{tabular}{llll}
\hline Research Flight & Date & Research Flight & Date \\
\hline RF 01 & $4 / 17 / 2006$ & RF 07 & $5 / 3 / 2006$ \\
RF 02 & $4 / 21 / 2006$ & RF 08 & $5 / 5 / 2006$ \\
RF 03 & $4 / 24 / 2006$ & RF 09 & $5 / 8 / 2006$ \\
RF 04 & $4 / 26 / 2006$ & RF 10 & $5 / 9 / 2006$ \\
RF 05 & $4 / 28 / 2006$ & RF 11 & $5 / 11 / 2006$ \\
RF 06 & $5 / 1 / 2006$ & RF 12 & $5 / 15 / 2006$ \\
\hline
\end{tabular}

C-130 performed 12 research flights as part of INTEX$\mathrm{B}$, including the transit flights between Washington and Colorado, where the plane is normally stationed. Table 1 lists the dates for the flights for the C-130 during INTEX-B; flight tracks are shown in Supplemental Figure S1: http://www.atmos-chem-phys.net/9/7257/2009/ acp-9-7257-2009-supplement.pdf. Most of these flights were designed to intercept transported Asian pollution layers as identified by chemical transport models. In this section, we describe the Aerodyne High Resolution Time-ofFlight Aerosol Mass Spectrometer (HR-ToF-AMS, hereafter referred to as "AMS") instrument, the inlet system used for the AMS, the other aerosol instruments deployed on board the $\mathrm{C}-130$ and comparisons amongst the aerosol instruments on the C-130 and on board other aircraft in the INTEX-B study.

\subsection{HR-ToF-AMS instrument}

The MILAGRO and INTEX-B field campaigns represented the first deployment of a HR-ToF-AMS on board an aircraft (DeCarlo et al., 2008). The HR-ToF-AMS has been described in detail elsewhere (Canagaratna et al., 2007; DeCarlo et al., 2006). The deployment of the AMS for INTEX$\mathrm{B}$ on the C-130 was carried out immediately after that for the MILAGRO campaign (DeCarlo et al., 2008), and only technical details that are different for the INTEX-B deployment are described here. Ionization efficiency (IE) calibrations were performed 24 times throughout the campaign on 9 different days using monodisperse $\mathrm{NH}_{4} \mathrm{NO}_{3}$ particles from $300-450 \mathrm{~nm}$ in diameter. There was no trend observed throughout the campaign in the IE calibrations and the average value of the IE to air beam $(\mathrm{AB})$ ratio for all calibrations was: $\mathrm{IE} / \mathrm{AB}=(5.29 \pm 0.99) \times 10^{13} \mathrm{~Hz}^{-1}$; this value was used to calculate all mass concentrations for the INTEX-B campaign. Two size calibrations were performed at the beginning of campaign (used for the first half of flights) and the end of campaign (used for the second half of flights); these calibrations were different by $<2 \%$. The size range of transmission of the AMS and the inlet line on the C-130 for the AMS is described in the next section. The strength of the signal pulse produced by the detection of a single ion (DeCarlo 

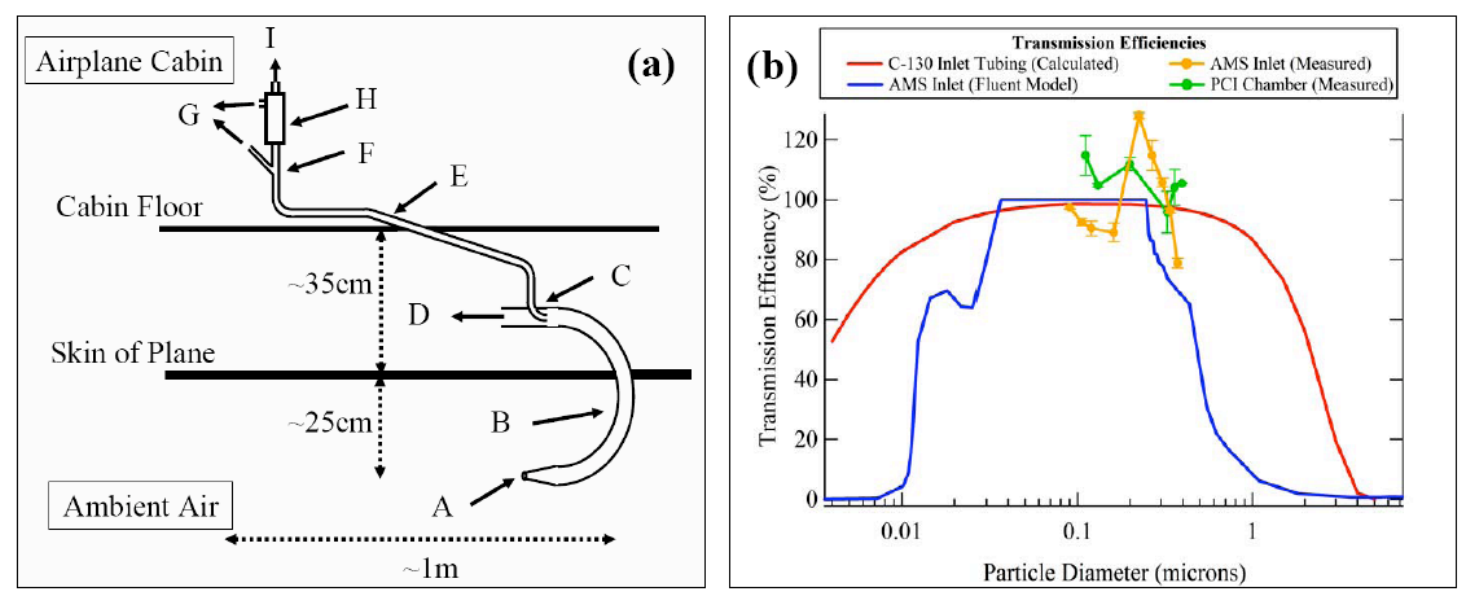

Fig. 1. Panel (a) shows a cross sectional schematic of the C-130 AMS/PILS inlet system; various parts of the inlet are as follows: A=Diffuser style inlet with $3 \mathrm{~mm}$ opening; $\mathrm{B}=1$ inch outer diameter $(\mathrm{OD})$ stainless steel tube smooth bends; $\mathrm{C}=\mathrm{Isokinetic}$ flow splitter; $\mathrm{D}=1$ inch $\mathrm{OD}$ tube to PILS; E=3/8 inch OD copper inlet line through cabin floor; F=Y style splitter; G=Bypass flows; H=Pressure controlled inlet (PCI, 350 Torr); I=Flow to AMS. Panel (b) shows transmission efficiency as a function of vacuum aerodynamic particle diameter for the three parts of the C-130 inlet system: the inlet tubing, the pressure controlled inlet, and the AMS critical orifice and aerodynamic lens (Jayne et al., 2000); the AMS critical orifice and lens are the limiting part of the system.

et al., 2006) was measured on 20 separate days during the campaign and an average value of $16.8 \pm 1.1$ bits ns was determined for the campaign, excluding the initial transit flight where a different voltage was applied to the microchannel plate detector (the detector voltage was increased after the transit flight due to slight detector degradation with age). The AMS collection efficiency (CE) was calculated based on the acidity of the particles, where $\mathrm{CE}=0.5$ for $\left(\mathrm{NH}_{4}\right)_{2} \mathrm{SO}_{4}$ and $\mathrm{NH}_{4} \mathrm{HSO}_{4}$, CE varies linearly below an ammonium to sulfate $\left(\mathrm{NH}_{4}^{+}\right.$to $\left.\mathrm{SO}_{4}^{=}\right)$molar ratio of $1: 1$, and $\mathrm{CE}=1$ for $\mathrm{H}_{2} \mathrm{SO}_{4}$. This is based on previous work from several groups for several different instruments and platforms showing that the CE varies with particle acidity (Kleinman et al., 2007; Quinn et al., 2006). We report concentrations of organics, sulfate, nitrate and ammonium from the AMS for the entire INTEX-B campaign at $12 \mathrm{~s}$ intervals with $>99 \%$ data coverage for the $94 \mathrm{~h}$ of flight time. Detection limits for the individual species are determined as $3 \times$ the measured standard deviation of the mass concentration of 12-s averaged measurements of filtered ambient air. For INTEX-B, the measured detection limits were: organics $=0.35 \mu \mathrm{g} \mathrm{sm}^{3}$, sulfate $=0.04 \mu \mathrm{g} \mathrm{sm}^{3}$, ammonium $=0.36 \mu \mathrm{g} \mathrm{sm}^{3}$ and nitrate $=0.06 \mu \mathrm{g} \mathrm{sm}^{3}\left(\mathrm{sm}^{-3}\right.$ refers to $\mathrm{m}^{-3}$ at standard temperature and pressure, STP, $1 \mathrm{~atm}$ and $273 \mathrm{~K})$. Overall loadings of chloride were below the instrument detection limit $\left(0.05 \mu \mathrm{g} \mathrm{sm}^{3}\right)$ for most of the campaign except for a few cases in the marine boundary layer, and are not discussed in this paper.

\subsection{Shared inlet for AMS and PILS on C-130}

The AMS and the Particle Into Liquid Sampler (PILS) instruments shared an inlet line on the C-130; the PILS instrument is described further in the next section. The inlet was located on the belly of the C-130, off of the center axis on the port (left) side of the aircraft, approximately $15 \mathrm{~m}$ (50 feet) aft from the nose of the aircraft (see http://mirage-mex.acd.ucar. edu/Measurements/C130/Images/C-130_layout.png). The depth of the boundary layer of the plane at this location was estimated at approximately $15 \mathrm{~cm}$ (6 inches) (based on rule of thumb that boundary layer is approximately $1 \%$ of distance from nose of aircraft), while the inlet tip was located $25 \mathrm{~cm}$ (10 inches) from the skin of the plane, ensuring sampling of unperturbed ambient air. Panel (a) of Fig. 1 shows the inlet system, while Table 2 documents the flow rates and residence times in each section. The inlet was a custom built diffuser style inlet (Wilson et al., 2001) with a $3 \mathrm{~mm}$ (0.12 inches) opening at the tip, expanding at an angle of 9.9 degrees over $5 \mathrm{~cm}$ ( 2 inches) to a $2.5 \mathrm{~cm}$ ( 1 inch) O.D. stainless steel tube (I.D. $=2.1 \mathrm{~cm}, 0.81$ inches). The $2.5 \mathrm{~cm}$ ( 1 inch) tube included two smooth 90 degree bends, one outside of the plane's skin and one just inside the plane's skin, over a tube length of less than $90 \mathrm{~cm}$ (36 inches). A $0.95 \mathrm{~cm}$ (3/8 inch) pick-off tube was inserted in a $2.5 \mathrm{~cm}$ (1 inch) tee to isokinetically split flow to the AMS ( $0.95 \mathrm{~cm}$ tube) and the PILS ( $2.5 \mathrm{~cm}$ tube). The $0.95 \mathrm{~cm}$ tubing for the AMS line included three smooth 90 degree bends over a total length of approximately $120 \mathrm{~cm}$ (48 inches). A "Y" splitter was used to divide the flow into the pressure controlled inlet (PCI) in front of the AMS and a bypass flow. The PCI has been described in detail elsewhere (Bahreini et al., 2008). Briefly, the PCI consists of an expansion chamber in which the pressure is maintained at a constant pressure, 350 Torr for this study, by a variable opening pressure controller using proportional-integral-derivative 
(PID) logic. The AMS sampled flow from this constant pressure region, avoiding the need for flow corrections with varying altitude up to $\sim 6.5 \mathrm{~km}(\sim 350$ Torr) (Bahreini et al., 2003). The residence time of air in the inlet line to the AMS instrument was calculated to be $4 \mathrm{~s}$ (Table 2).

Losses for submicron particles in the inlet line were estimated with empirical correlations (Baron et al., 2001; Hinds, 1999). Based on the Reynolds number for altitudes up to $8 \mathrm{~km}$, flow was turbulent through the inlet tip, but was either laminar or in the transition region between laminar and turbulent $(1000<\operatorname{Re}<2500)$ for the remainder of the inlet line. The calculated diffusional and inertial depositional losses for particles between $0.02-1.5 \mu \mathrm{m}$ in diameter were $<3 \%$. Losses due to misalignment of the inlet tip with respect to the direction of the plane's flight were estimated to be negligible for submicron particles (see; Hinds, 1999; Fig. 10.3 and Eq. 10.5). The velocity ratio of the airplane speed to the sampling velocity of air through the inlet tip was approximately 0.9 , leading to minimal losses due to non-isokinetic sampling (see; Hinds, 1999; Fig. 10.4 and Eq. 10.7). An estimated inlet transmission efficiency curve accounting for all of these losses is shown in Fig. 1, panel (b), assuming typical conditions for flight altitude $(5 \mathrm{~km})$, plane speed $(210 \mathrm{kts})$, velocity ratio in the AMS pick-off splitter (2), velocity ratio at the inlet tip (0.9), and particle density $\left(1.5 \mathrm{~g} \mathrm{~cm}^{3}\right)$, as well as assuming an upper limit of the misalignment of the inlet (5 degrees). Laboratory tests were performed to measure the particle transmission losses in the PCI and AMS inlet (Bahreini et al., 2008). These losses in the PCI and AMS inlet were minimal over the vacuum aerodynamic diameter size range, $d_{\mathrm{va}}=100$ to $600 \mathrm{~nm}$, in good agreement with the modeling of the AMS inlet transmission (Jayne et al., 2000); see Fig. 1, panel (b). The size cut of the AMS inlet (using a critical orifice from the PCI to maintain a pressure of 1.4 Torr in the aerodynamic lens) was the limiting factor in the transmission size range for this inlet system.

The total heating of air in the inlet line from ram and cabin heating ensured that the sampled aerosol was dry. Ram heating was estimated to raise the temperature of the sampled air by $\sim 20^{\circ} \mathrm{C}$ and cabin heating by an additional $5-35^{\circ} \mathrm{C}$. Laboratory studies of evaporation of semivolatile materials from particles upon heating, with at least twice the residence time than in this inlet, show that this amount of heating leads to, at most, 5-15\% losses of organic aerosol (Huffman et al., 2008, 2009), assuming the organic aerosol is highly oxygenated, which we show below is the case for INTEX-B. These possible evaporation losses could have potentially affected all instruments sampling air into the C-130. The AMS/PILS inlet system did not result in significant additional losses of submicron particle mass, as confirmed by comparisons with other particle instruments on board the $\mathrm{C}-130$, as well as those on board other aircraft with which the $\mathrm{C}$-130 intercompared (see next two sections).
Table 2. Flow rates and residence times of air in the C-130 AMS inlet system.

\begin{tabular}{lcc}
\hline Section of inlet line & $\begin{array}{c}\text { Flow rate (lpm at } \\
\text { ambient conditions) }\end{array}$ & $\begin{array}{c}\text { Residence } \\
\text { Time (s) }\end{array}$ \\
\hline Inlet tip to isokinetic splitter & 38 & 0.5 \\
Isokinetic splitter to PCI of AMS & 8 & 0.3 \\
Within PCI in front of AMS & - & 3.2 \\
Total from inlet tip to AMS & - & 4.0 \\
\hline
\end{tabular}

\subsection{Descriptions of other instrumentation on board C-130 aircraft and models in INTEX-B study}

The Particle Into Liquid Sampler - Ion Chromatography instrument (PILS-IC) quantitatively captures particles into a liquid stream that is subsequently analyzed by two ion chromatographs. The aerosol was passed through a non-rotating multi-orifice impactor that had a nominal cut size of $1 \mu \mathrm{m}$ at 1 atmosphere, decreasing to about $0.9 \mu \mathrm{m}$ at the maximum altitude (Peltier et al., 2008). The PILS reported $90 \mathrm{~s}$ integrated measurements of cation concentrations, e.g. $\mathrm{NH}_{4}^{+}$, $\mathrm{K}^{+}, \mathrm{Ca}^{+}$, every $2.45 \mathrm{~min}$, and $60 \mathrm{~s}$ integrated measurements of anion concentrations, e.g. $\mathrm{SO}_{4}^{=}, \mathrm{NO}_{3}^{-}, \mathrm{Cl}^{-}$, every $75 \mathrm{~s}$. Only concentrations of sulfate and nitrate are used in this study.

The Texas A\&M Scanning Mobility Particle Sizer (SMPS) (Wang et al., 1990) reported dry size distributions for particles between 0.012 and $0.67 \mu \mathrm{m}$ mobility diameter once every $90 \mathrm{~s}$. SMPS distributions recorded above $5 \mathrm{~km}$ were discarded as post-project comparison with other datasets revealed that an improperly seated o-ring caused a leak as the pressure differential exceeded a certain threshold; this also caused problems during sharp changes in altitude.

The University of Hawaii operated several aerosol instruments, including a Differential Mobility Analyzer (DMA) and an Optical Particle Counter (OPC) to measure the particle number size distribution. The DMA measurements cover the size range of $20-150 \mathrm{~nm}$ and the OPC measurements cover the aerosol diameter size range $150-750 \mathrm{~nm}$. Thus, the sum of the DMA+OPC provides a more accurate measure of the submicron volume than either measurement individually. Aerosol number concentrations were measured with two TSI Condensation Particle Counters (TSI model 3010 and 3025) covering the size range of $>10 \mathrm{~nm}$ (condensation nuclei, $\mathrm{CN}$ ) and $>3 \mathrm{~nm}$ (ultra-fine condensation nuclei, UFCN). Two TSI model 3563 3-wavelength integrating nephelometers (Anderson et al., 1996, 2003; Heintzenberg et al., 1996) measured total and submicrometer aerosol scattering coefficients at 450,550 and $700 \mathrm{~nm}$.

The Single Particle Soot Photometer (SP2) instrument $\mathrm{http} / / / \mathrm{www} . d$ ropletmeasurement.com/products/SP2.htm) is a three-color incandescence measurement of individual light absorbing particles, which is highly specific for black carbon (soot). The nephelometers, SMPS and SP2 instruments all shared an inlet. 
In this study, we use data from several other measurements made on board the C-130 during INTEX-B. The C-130 instrumentation package included standard physical measurements, such as latitude, longitude, altitude that are used in this study (http://www.eol.ucar.edu/raf/). Methyl tertiary butyl ether (MTBE) and halon H-1211 were measured by fast gas chromatography (TOGA) (Apel et al., 2003) and whole air canister sampling (Baker et al., 2007) respectively. Nitric acid $\left(\mathrm{HNO}_{3}\right)$ and sulfur dioxide $\left(\mathrm{SO}_{2}\right)$ were measured with a chemical ionization mass spectrometry technique (Crounse et al., 2006). Ozone $\left(\mathrm{O}_{3}\right)$ and reactive nitrogen $\left(\mathrm{NO}_{\mathrm{y}}\right)$ were measured with the NCAR 4-channel chemiluminescence instrument (Ridley et al., 2004).

We use several modeling products to inform our analysis. Back trajectory analyses from the FLEXPART particle dispersion model (http://zardoz.nilu.no/ Eandreas/MILAGRO_ ETC/index.html) and from the Global Forecast System (http: //fuelberg.met.fsu.edu/research/nasa_intexb.html) are used to examine air mass history. We also include results from two chemical transport models (MOZART-4 and GEOS-Chem) to interpret our observations and test current understanding.

MOZART-4 (Model for OZone And Related chemical Tracers, version 4) is a global chemical transport model with 97 chemical species representing tropospheric chemistry with bulk aerosols (Emmons et al., 2008). For this analysis, MOZART-4 was driven by meteorological fields from the National Centers for Environmental Prediction/Global Forecast System (NCEP/GFS), with a horizontal resolution of $1.4^{\circ} \times 1.4^{\circ}$ longitude and a vertical grid of 42 sigma-levels extending from the surface up to about $2 \mathrm{hPa}$ (Horowitz et al., 2003; Pfister et al., 2008). Anthropogenic emissions for Asia are from the inventory by D. Streets (Argonne National Laboratory) representing 2006, and for the rest of the globe from the POET (Precursors of Ozone and their Effects in the Troposphere) database for 2000 (Granier et al., 2004). Biomass burning emissions are from the Global Fire Emissions Database, version 2 (GFED-v2) (van der Werf et al., 2006). Biogenic emissions for isoprene and terpenes are determined online using the MEGAN algorithm (Guenther et al., 2006). The representation of tropospheric aerosols in MOZART-4 includes the calculation of sulfate, black carbon, primary organic, secondary organic (SOA), ammonium nitrate, sea salt and dust particles (Lamarque et al., 2005). Sulfate aerosols are determined from emissions of $\mathrm{SO}_{2}$ and DMS. Black carbon and primary organic are emitted in a combination of hydrophobic and hydrophilic forms $(80 \%$ and 50\% hydrophobic, respectively), and are converted from hydrophobic to hydrophilic with a 1.6 day time constant. Secondary organic aerosols are linked to the gas-phase chemistry through the oxidation of atmospheric VOCs as in Chung and Seinfeld (2002).

GEOS-Chem (v7-04, http://www.as.harvard.edu/ctm/ geos/) is driven by GEOS-4 assimilated meteorology from the NASA Global Modeling and Assimilation Office. The meteorological data have 6-h temporal resolution (3-h for surface variables and mixing depth), $1^{\circ} \times 1.25^{\circ}$ horizontal resolution, and 55 layers in the vertical. Here we degrade the resolution to $2^{\circ} \times 2.5^{\circ}$ and 30 layers for input to GEOS-Chem and spin the model up for 1 year to remove the influence of initial conditions. GEOS-Chem includes detailed ozone$\mathrm{NO}_{\mathrm{x}}$-VOC chemistry coupled to externally-mixed aerosols (Bey et al., 2001; Park et al., 2004b, 2006). Anthropogenic emissions are based on the EPA 1999 National Emissions Inventory (http://www.epa.gov/ttn/chief/net/) over the US, Streets et al. (http://www.cgrer.uiowa.edu/ EMISSION_DATA_new/index_16.html) over Asia, BRAVO (Kuhns et al., 2005) over Mexico, EMEP (Auvray et al., 2005) over Europe, and EDGAR (http://www.mnp.nl/edgar/) elsewhere. Biogenic emissions of isoprene and terpenes are from MEGAN (Guenther et al., 2006). Simulation of POA and sulfate/nitrate/ammonium is as described elsewhere (Park et al., 2003, 2004b), and SOA formation from isoprene, monoterpenes, sesquiterpenes, and terpenoid alcohols is simulated based on a previous gas-particle portioning model (Chung et al., 2002; Heald et al., 2005; Liao et al., 2007). Dry deposition of gases and aerosols uses a resistance-in-series model (Wang et al., 1998; Wesely, 1989), and wet deposition is as described elsewhere (Liu et al., 2001; Mari et al., 2000).

\subsection{Aerosol instrument intercomparisons}

All aerosol measurements presented here are reported as concentrations at standard temperature and pressure (STP), defined as $T=273 \mathrm{~K}$ and $P=1013 \mathrm{mbar}$. For the AMS, the measured submicron mass was converted to volume using a density determined from the AMS chemical composition measurements, assuming the following densities $\left(\right.$ in $\mathrm{g} \mathrm{cm}^{3}$ ): Organics $=1.27$ (Cross et al., 2007), Sulfate $=1.78$, Nitrate $=1.72$, and Ammonium=1.75, based on the densities of ammonium sulfate and ammonium nitrate (Lide et al., 2007). The initial flow rate calibration of the AMS was performed at $295 \mathrm{~K}$ and corrected to STP. Because the AMS sampled through a PCI, which maintained a constant pressure within $5 \%$ for $>90 \%$ of the measurement time, the measured flow rates were corrected only for variations in sampling temperature as measured at the AMS lens (periods where the pressure in the PCI decreased by more than $5 \%$ were during flight segments $>23000 \mathrm{ft}$ where there was little submicron aerosol mass). The black carbon (BC) mass measurements from the SP2 instrument were converted to volume using a density of $1.77 \mathrm{~g} \mathrm{~cm}^{-3}$ from the literature (Bond et al., 2006; Park et al., 2004a). The AMS measures the mass of non-refractory material, thus summing together the AMS and BC measurements provides a more accurate measure of total submicron volume. (As seen in later Supplemental Figure S3: http://www.atmos-chem-phys.net/9/7257/ 2009/acp-9-7257-2009-supplement.pdf and Table 3, BC accounts for a small percentage of the submicron mass, so the comparisons of AMS+BC with other volume measurements 


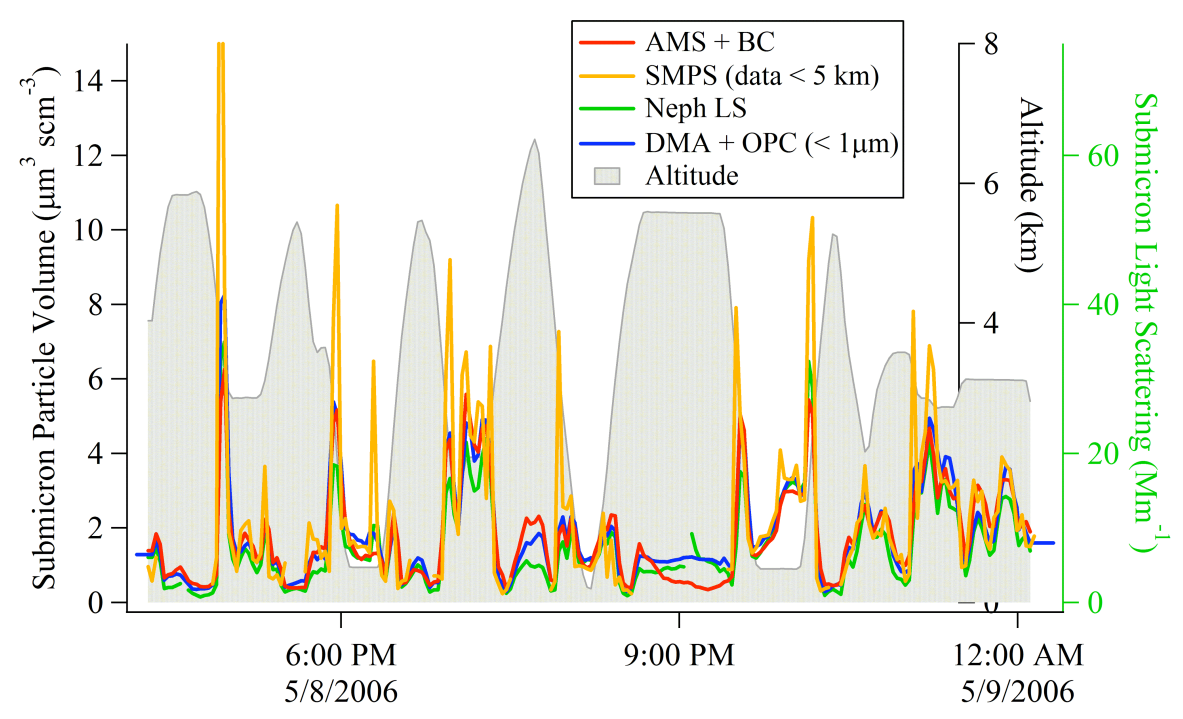

Fig. 2. This example time series from INTEX-B research flight 09 shows measurements of submicron particle volume from the AMS, SMPS and the sum of the DMA+OPC, and submicron light scattering signal from the nephelometer. The C-130 altitude is plotted for reference; time is in UTC. Only SMPS data from altitudes below $5 \mathrm{~km}$ is shown (see text for explanation). The spike in the SMPS data at 05:56 p. $\mathrm{m}$. UTC is not shown to its fullest height $\left(24.8 \mu \mathrm{m}^{3} \mathrm{scm}^{3}\right)$.

here is primarily a comparison of the AMS). We note that this quantity does not include submicron dust, but dust would only contribute to the submicron volume during periods of very high dust loading, since only a few percent of the dust mass is in the submicron range (Maring et al., 2003). High dust periods (submicron light scattering to total light scattering ratio of $<0.3$ (Anderson et al., 2003)) accounted for $<6 \%$ of the time during INTEX-B.

The data from the AMS is compared to other instruments in Figs. 2, 3a and b. As an example, the time series comparisons of the submicron total light scattering measurement and the three measurements of aerosol volume are shown for research flight 09 in Fig. 2; these have been averaged onto to the same time base as the SMPS (roughly every $90 \mathrm{~s})$. Scatter plot comparisons for the whole campaign in Fig. $3 \mathrm{a}$ and $\mathrm{b}$ show good agreement amongst the three measurements of total submicron volume. Linear least squares fits reveal slopes of $0.98 \pm 0.01$ ( $1 \sigma$ standard deviation of linear fit; $\left.R^{2}=0.83\right)$ and $1.02 \pm 0.02(1 \sigma$ standard deviation of linear fit; $\left.R^{2}=0.60\right)$ for the comparisons of $(\mathrm{DMA}+\mathrm{OPC}) \mathrm{vs}$ $(\mathrm{AMS}+\mathrm{BC})$ and SMPS vs $(\mathrm{AMS}+\mathrm{BC})$ respectively. These results are consistent with those from DeCarlo et al. (2008) for the MILAGRO portion of this deployment.

Comparisons of the PILS-IC and AMS chemical species measurements were carried out for sulfate and nitrate (ammonium did not have enough points above detection limit $\left(0.1 \mu \mathrm{g} \mathrm{sm}^{3}\right)$ in the PILS data for a proper comparison). The AMS data for Fig. 3c and d have been averaged onto to the same time base as the PILS-IC instrument, which reported anion measurements every $75 \mathrm{~s}$. The slopes of the regressions for both inorganic species are within $20 \%$ and the regressions are dominated by a few large plumes. The nitrate data is relatively sparse owing to the low number of time periods when the nitrate loadings were above the PILS detection limit $\left(0.02 \mu \mathrm{g} \mathrm{sm}^{3}\right)$ during the INTEX-B campaign. This level of agreement is consistent with the combined instrumental accuracies of $\pm 10 \%$ for the PILS and $\pm 30 \%$ for the AMS, and is similar to that obtained in recent ground-based field campaigns with much longer integration times $(1 \mathrm{~h})$ and typically higher concentrations (Takegawa et al., 2005; Zhang et al., 2005b). The scatter is larger for the present study, mostly due to the very short integration times (75 s); in the AMS and in most other instruments the noise in the averaged concentrations is reduced as the square root of the averaging time.

As an additional check on the AMS quantification, we compared the total submicron scattering calculated from the AMS concentrations and size distributions with the measured submicron scattering value from the nephelometer. Refractive indices were calculated from the measured AMS chemical composition (Hand et al., 2002), assuming linear mixing (d'Almeida et al., 1991). The agreement of the calculated scattering from the AMS size distributions with the nephelometer measurements is good; this is presented elsewhere (Fig. 2 in (DeCarlo, et al., 2008)).

Overall, the agreement amongst the various aerosol instruments on board the C-130 was within $20 \%$. This shows that there were not significant differences between the particle losses for any of the C-130 aerosol inlets in this study.

In addition to the instrument comparisons performed on board the C-130, two intercomparisons of the C-130 and DC8 were performed, one on 4/17/2006 and one on 5/15/2006. The results of these intercomparisons are described in 

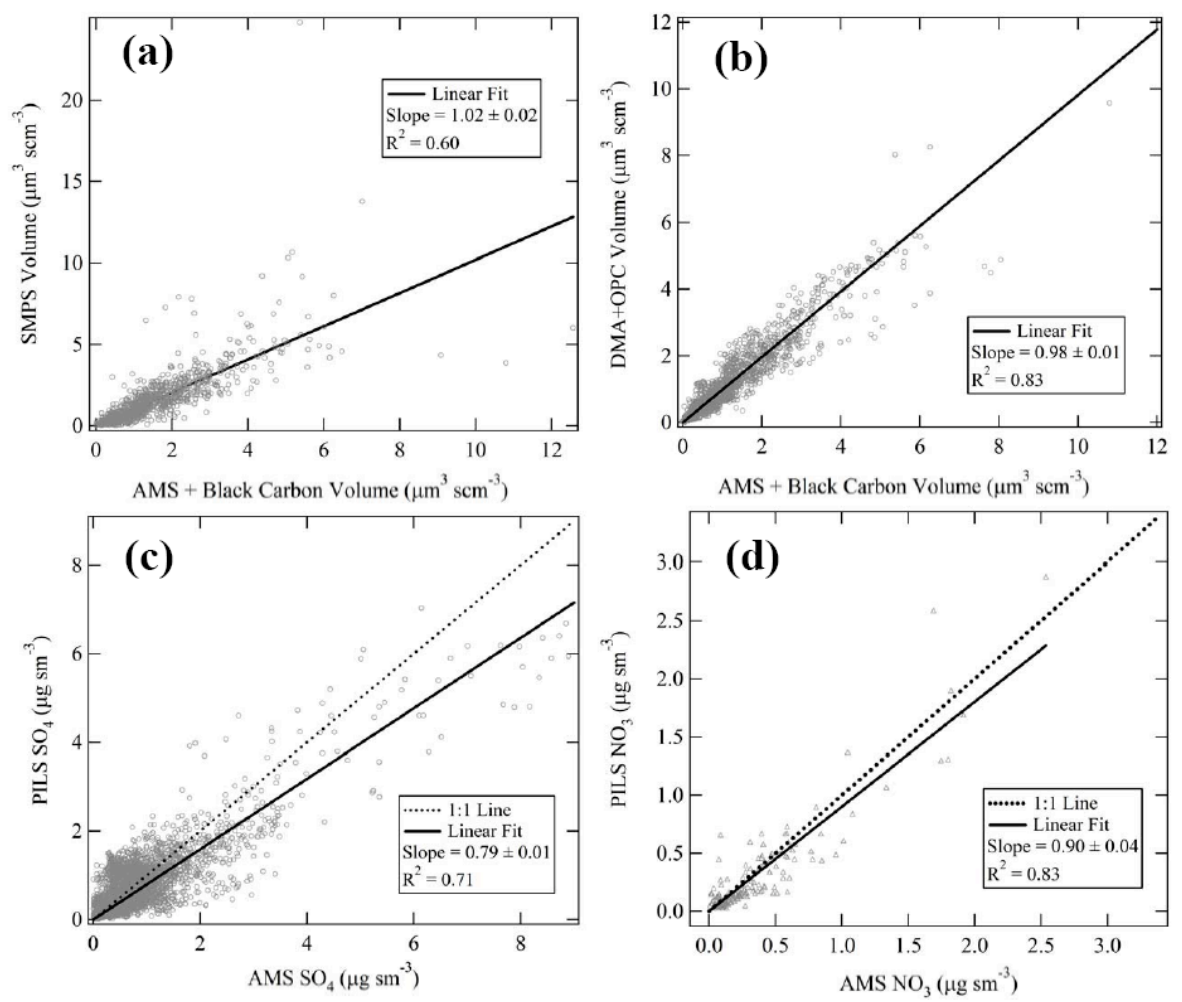

Fig. 3. Scatter plot of measurements of submicron particle volume and particle anion species concentrations from instruments on board the C-130 for the entire INTEX-B campaign. In panel (a), the SMPS submicron volume is plotted versus the sum of the AMS+BC instruments; in panel (b), the sum of the DMA+OPC measurements is plotted versus the sum of the AMS+BC instruments; panel (c) shows the comparison for aerosol sulfate between the PILS and AMS instruments; and panel (d) shows the comparison for aerosol nitrate between the PILS and AMS instruments. Note that " $\mathrm{scm}^{3}$ " stands for $\mathrm{cm}^{3}$ at STP and " $\mathrm{sm}^{3}$ " stands for $\mathrm{m}^{3}$ at STP.

Supplemental Sect. S.1: http://www.atmos-chem-phys.net/ 9/7257/2009/acp-9-7257-2009-supplement.pdf. Additionally, two intercomparisons of the C-130 and Canadian Cessna aircraft were performed, once on 5/3/2006 and once on 5/9/2006. The two planes flew spirals in the same geographic location, separated in time by approximately an hour in each case. The Canadian Cessna had a quadrupole AMS (Q-AMS) on board. The comparisons of the Cessna Q-AMS with the C-130 HR-ToF-AMS for four measured submicron aerosol chemical species (organics, sulfate, nitrate and ammonium) are in good agreement. This information is presented elsewhere (van Donkelaar et al., 2008).

\section{Results}

Most of the C-130 flight plans during INTEX-B involved time spent attempting to intercept Asian pollution layers that were predicted to have been transported to the Eastern Pacific. The typical flight pattern involved frequent vertical profiling between $\sim 0.6 \mathrm{~km}$ to above $6 \mathrm{~km}$ (maximum altitude of $7.5 \mathrm{~km}$ ). From this data set, we have defined four separate categories of air masses: transported Asian pollution layers, the free troposphere, the Central Valley of California, and the Seattle region. These categories and the selection criteria are discussed in Sects. 3.1 and 3.2 below. Overall campaign averages for the mass concentrations of non-refractory, submicron particle species as measured by the AMS are listed in Table 3 and shown in Supplemental Fig. S3: http://www.atmos-chem-phys. net/9/7257/2009/acp-9-7257-2009-supplement.pdf; vertical profiles are shown in Supplemental Fig. S4: http://www.atmos-chem-phys.net/9/7257/2009/ acp-9-7257-2009-supplement.pdf.

\subsection{Transported Asian pollution layers}

Layers were identified as originating from Asia with several complementary criteria, the most important of which is the presence of sulfate above the free tropospheric background, as described below. First, meteorological modeling work from both FLEXPART and Global Forecast System (Sect. 2.3) was used to evaluate air masses with back trajectories that extended to the Asian continent (see Peltier et al., 2008, for examples). Additionally, $\mathrm{CO}, \mathrm{O}_{3}$ and $\mathrm{NO}_{\mathrm{y}}$, which are indicative of anthropogenic pollution, were typically elevated in air masses with back trajectories originating 
from Asia. All of these factors were used in several test cases (see Sect. 3.1.1 for example), establishing that elevated levels of sulfate were also indicative of Asian pollution. Chemical transport modeling carried out as part of the INTEX-B study supports the association of elevated sulfate with Asian pollution layers (van Donkelaar et al., 2008). We note that elevated sulfate has been observed previously in transported Asian pollution layers (Andreae et al., 1988; Brock et al., 2004).

On board chemical tracer measurements were also used to establish that air masses were from Asia. In particular, the presence of MTBE is an indicator of Asian origin because this compound is used as a gasoline additive in Asia, and no longer in North America (West et al., 2007). MTBE has a typical lifetime in the atmosphere of a few days with respect to loss by reaction with the hydroxyl radical $(\mathrm{OH})$ (Bonard et al., 2002) ( 4 days at $[\mathrm{OH}]=1 \times 10^{6}$ molecule $\mathrm{cm}^{-3}$ ). Figure 4 shows the correlation of aerosol sulfate and MTBE. All elevated sulfate time periods show elevated MTBE, confirming the Asian origin of the air masses with the highest sulfate levels during this campaign.

Using this observation that Asian pollution contains elevated sulfate levels, we classify "Asian pollution layers" that contain sulfate as those air masses that were intercepted west of -125 longitude (over the sea slightly off the Western US coast) and contained an aerosol sulfate loading of $>1 \mu \mathrm{g} \mathrm{sm}^{3}$ (where $\mathrm{sm}^{3}$ refers to $\mathrm{m}^{3}$ at $\mathrm{STP}$ ) as measured by the AMS. We used the measured potential temperature profiles to determine the height of the marine boundary layer (MBL) and only used data for this category above the MBL. This definition may ignore less concentrated Asian pollution layers that have lower sulfate loadings, but should be restrictive enough to exclude other types of layers. Other types of air masses with large sulfate loadings would most likely originate from either North American pollution or MBL sulfate production. The use of data west of -125 longitude excludes North American pollution layers, as does the use of MTBE as a tracer (Fig. 4 shows no data with elevated sulfate but no elevated MTBE). MBL sulfate production is primarily from DMS oxidation and subsequent sulfate production via sulfuric acid. Oxidation of DMS also produces methanesulfonic acid (MSA), which condenses into the particle phase. Layers enhanced in MSA (as indicated by the $\mathrm{CH}_{3} \mathrm{O}_{2} \mathrm{~S}^{+}$ion; Sun et al., 2008, 2009; Zorn et al., 2008) accounted for $<1$ minute's worth of data within the category of Asian ( $0.1 \%$ of the "Asian Layer" data points), indicating that our definition for Asian is stringent enough to exclude air influenced by the MBL. Figure 5 shows an example "Marine Layer" that is slightly enhanced in sulfate $\left(<1 \mu \mathrm{g} \mathrm{m}^{3}\right)$ and contains elevated MSA. This is important in establishing sulfate as a robust tracer of Asian pollution in this study, showing that sulfate is not produced from DMS oxidation for the layers in this study. This is consistent with previous results over the Northeast Pacific showing that production of sulfate from DMS generally occurred in the boundary layer and

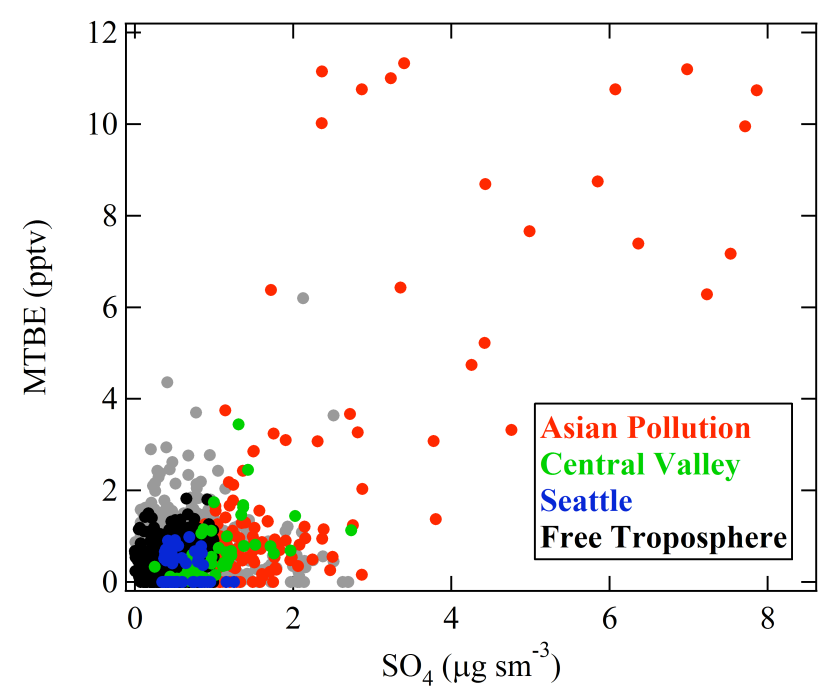

Fig. 4. Correlation plot of MTBE from the TOGA instrument versus particulate phase sulfate from the AMS. Unclassified points are in gray.

that sulfate in the free troposphere was mainly from Asian transport (Andreae et al., 1988). Overall by this definition, sampling of Asian pollution layers accounted for $8 \%$ of total sampling time during the INTEX-B campaign; this amounts to sampling of approximately a dozen Asian pollution layers, where the two case studies described below that account for $17 \%$ of the Asian pollution air mass category. Our approach is complementary to that of Peltier et al. (2008), but our approach is more restrictive.

On average, the INTEX-B campaign shows a larger percentage of sulfate compared to organic aerosol (Table 3). This is presumably the result of the large degree of sampling of Asian pollution layers, which are dominated by sulfate. The processed Asian pollution aerosol is distinctly acidic, with an average $\mathrm{NH}_{4}^{+}: \mathrm{SO}_{4}^{=}$molar ratio of 1.0 , consistent with ammonium bisulfate, $\mathrm{NH}_{4} \mathrm{HSO}_{4}$. Another study (Ooki et al., 2007) has shown that, within the accumulation mode for anthropogenic aerosol transported over the Pacific Ocean for 3 days and sampled in the MBL, smaller particles $(<0.22 \mu \mathrm{m})$ generally show a neutral ion balance for ammonium compared to sulfate, but that larger particles $(>0.22 \mu \mathrm{m})$ show a deficit of ammonium (equivalent ratio of $\mathrm{NH}_{4}^{+} /$non-sea-salt- $\mathrm{SO}_{4}^{=}$in the accumulation mode was 0.73 ). This is broadly consistent with our measurements since the Asian aerosol in the MBL is somewhat less acidic than in higher layers (Supplemental Fig. S4: http://www.atmos-chem-phys.net/9/7257/2009/ acp-9-7257-2009-supplement.pdf). Average vertical profiles (Supplemental Fig. S4: http://www.atmos-chem-phys.net/ 9/7257/2009/acp-9-7257-2009-supplement.pdf) of the various air mass types reveal that most species are relatively constant with altitude, with the exception of the expected 
Table 3. Average mass loadings as measured by the HR-ToF-AMS on board the C-130 for various types of air masses with maximum values listed in parentheses. See text for definitions of air mass categories. $\mathrm{a}=$ concentration in $\mu \mathrm{g} \mathrm{sm}^{-3} ; \mathrm{b}=$ fraction of measured $\mathrm{NH}_{4}^{+}$compared to $\mathrm{NH}_{4}^{+}$concentration necessary to neutralize anions; $\mathrm{c}=$ concentration in $\mu \mathrm{g} \mathrm{sm}^{-3}$ as measured by SP 2 instrument; $\mathrm{d}=\mathrm{gas}$ phase concentration of $\mathrm{SO}_{2}$ in ppbv as measured by CIMS instrument, no $\mathrm{SO}_{2}$ measurements were available for the Seattle flight.

\begin{tabular}{lcccccccc}
\hline & $\mathrm{Total}^{\mathrm{a}}$ & $\mathrm{SO}_{4}^{a}$ & $\mathrm{Org}^{a}$ & $\mathrm{NO}_{3}^{-\mathrm{a}}$ & $\mathrm{NH}_{4}^{+\mathrm{a}}$ & $\begin{array}{c}\mathrm{NH}_{4}^{+} \\
\text {Measured/ } \\
\mathrm{Neutral}^{\mathrm{b}}\end{array}$ & $\mathrm{BC}^{\mathrm{c}}$ & $\mathrm{SO}_{2}^{\mathrm{d}}$ \\
\hline Campaign Average & 1.70 & 0.73 & 0.55 & 0.05 & 0.18 & 0.63 & 0.14 & 0.21 \\
& $(46.5)$ & $(10.8)$ & $(37.3)$ & $(3.8)$ & $(2.0)$ & & $(2.8)$ & $(5.1)$ \\
\hline Central Valley & 4.85 & 1.04 & 2.35 & 0.28 & 0.33 & 0.72 & 0.57 & 0.36 \\
& $(46.5)$ & $(3.3)$ & $(37.3)$ & $(3.8)$ & $(1.5)$ & & $(2.8)$ & $(2.8)$ \\
\hline Seattle region & 2.25 & 0.61 & 0.93 & 0.06 & 0.19 & 0.79 & 0.40 & $\mathrm{NA}$ \\
& $(7.8)$ & $(2.8)$ & $(4.4)$ & $(0.7)$ & $(0.5)$ & & $(2.0)$ & 0.09 \\
\hline Free Trop & 0.76 & 0.35 & 0.18 & 0.01 & 0.12 & 0.92 & 0.07 \\
& $(7.5)$ & $(1.0)$ & $(4.8)$ & $(0.9)$ & $(0.5)$ & & $(1.1)$ & $(0.8)$ \\
\hline Asian Pollution & 3.50 & 2.02 & 0.85 & 0.06 & 0.38 & 0.50 & 0.13 & 0.58 \\
& $(16.0)$ & $(9.4)$ & $(8.5)$ & $(0.6)$ & $(1.4)$ & & $(1.2)$ & $(5.1)$ \\
\hline Younger Asian Pollution Layer & 8.47 & 5.36 & 2.61 & 0.13 & 0.36 & 0.20 & 0.03 & 2.36 \\
& $(14.8)$ & $(9.5)$ & $(4.7)$ & $(0.4)$ & $(0.7)$ & & $(0.3)$ & $(5.1)$ \\
\hline Older Asian Pollution Layer & 2.49 & 1.95 & 0.26 & 0.01 & 0.27 & 0.38 & 0.06 & 0.12 \\
& $(4.3)$ & $(3.5)$ & $(1.2)$ & $(0.1)$ & $(0.5)$ & & $(0.2)$ & $(0.3)$ \\
\hline
\end{tabular}

enhancement of all species in the boundary layer over the Central Valley (see Sect. 3.2.2) and an enhancement of sulfate at $\sim 6 \mathrm{~km}$ in the Asian aerosol; this latter feature is driven by the highly concentrated Asian pollution layer intercepted on the 5/1/2006 research flight (see Sect. 3.1.1). As a reminder, these measurements are of submicron particles from exported Asian pollution, which have been shown to be only episodically influenced by dust in general, and only in specific episodes (Massling et al., 2007), because only a few percent of the dust mass is below one micron (Maring et al., 2003). As noted above, high dust periods accounted for $<6 \%$ of the sampling time during the entire INTEX-B campaign and $<4 \%$ of the sampling time during Asian pollution layers.

\subsubsection{Case study of younger Asian pollution layer from 5/1/2006 flight}

The flight plan for research flight 06 on 5/1/2006 was designed to intercept a predicted Asian pollution layer off the coast of Seattle. The C-130 did indeed intercept a distinct layer at around $20000 \mathrm{ft}$ on two separate occasions during the flight. The chemical composition of the aerosol in this layer was heavily dominated by sulfate, as seen in Fig. 5. (Also see Supplemental Fig. S5: http://www.atmos-chem-phys.net/ 9/7257/2009/acp-9-7257-2009-supplement.pdf for the time series of several species not displayed in Fig. 5.) Back trajectories from FLEXPART (Fig. 6) indicate that this air mass was lifted from near the surface just off of the coast of China approximately 3 days prior to this flight and then transported rapidly at an altitude of approximately $5 \mathrm{~km}$ across the Pacific. This layer was transported just ahead of a band of clouds visible on satellite imagery from GOES (Fig. 7), moving from Asia to North America in 3 days, which is typical of a warm conveyor belt lifting event (Cooper et al., 2004). MTBE and H-1211 are chemical tracers for Asian pollution. MTBE (shown in Fig. 5) is greatly enhanced in this pollution layer; the lifetime of MTBE in the atmosphere is only several days, consistent with the rapid transport of this layer. Halon-1211 (Supplemental Fig. S5: http://www.atmos-chem-phys.net/9/7257/2009/ acp-9-7257-2009-supplement.pdf) is generally indicative of emissions from developing countries, including China (Barletta et al., 2006; Montzka et al., 2003) and is also enhanced in this pollution layer. This Asian pollution layer also shows an enhancement of $\mathrm{CH}_{3} \mathrm{I}$ (shown in Supplemental Fig. S5 http://www.atmos-chem-phys.net/9/7257/2009/ acp-9-7257-2009-supplement.pdf), which is most likely from emissions from rice paddies that are highly localized in southeast Asia (Bell et al., 2002). This layer is also enhanced in $\mathrm{CO}, \mathrm{O}_{3}, \mathrm{NO}_{\mathrm{y}}$, ethyne, $\mathrm{C}_{2} \mathrm{Cl}_{4}$ (shown in Supplemental Fig. S5: http://www.atmos-chem-phys.net/9/7257/ 2009/acp-9-7257-2009-supplement.pdf), and all classes of gas-phase organics measured on board the $\mathrm{C}$-130, including 


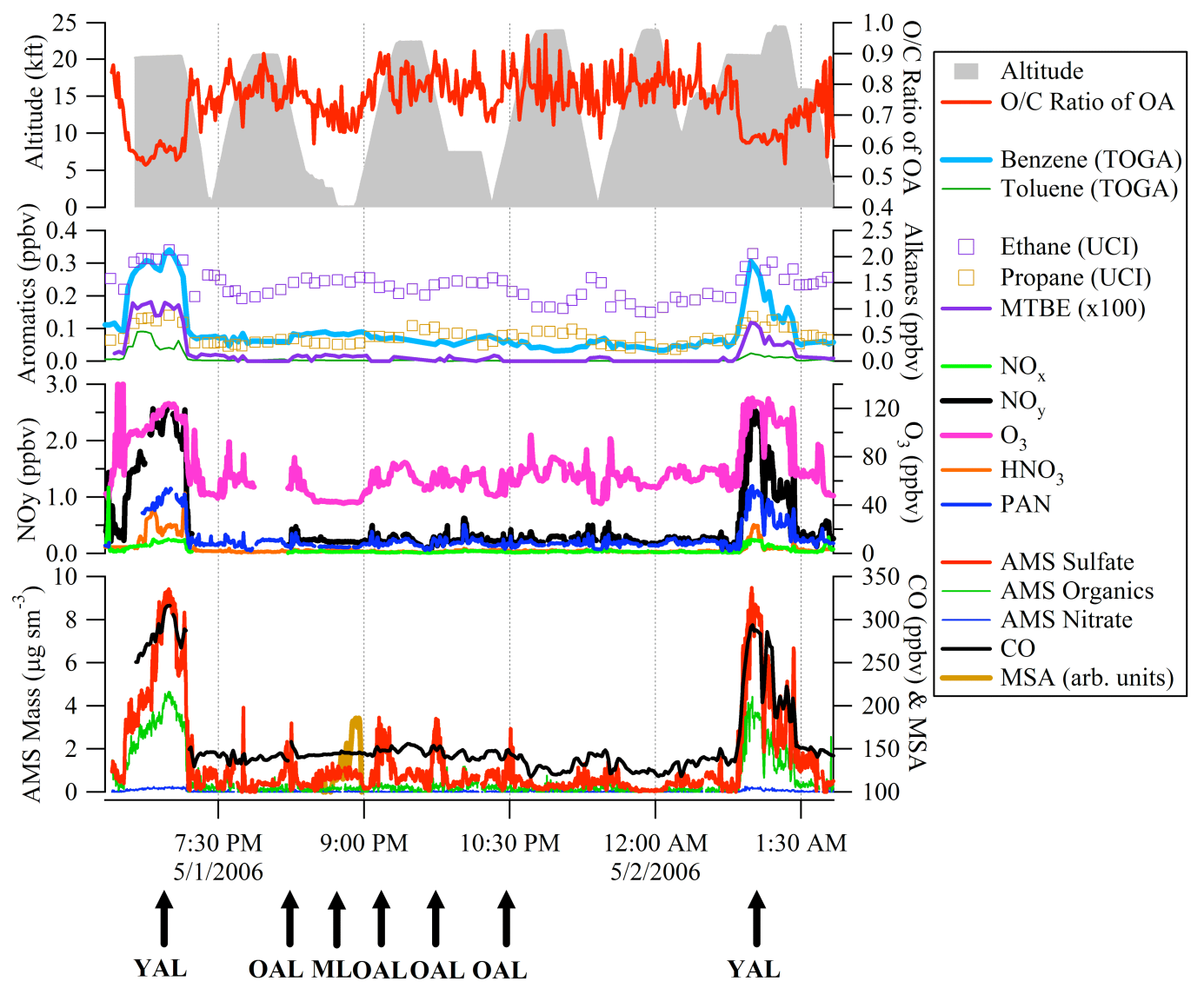

Fig. 5. Time series of measured species during 5/1/2006 research flight. Two intercepts of the Younger Asian Layer (YAL), several intercepts of the Older Asian Layer (OAL) and the one Marine Layer (ML) that are discussed in the text are labeled. The time is in UTC; trace for MSA has been smoothed with 2 min boxcar smoothing.

Younger Asian Layer
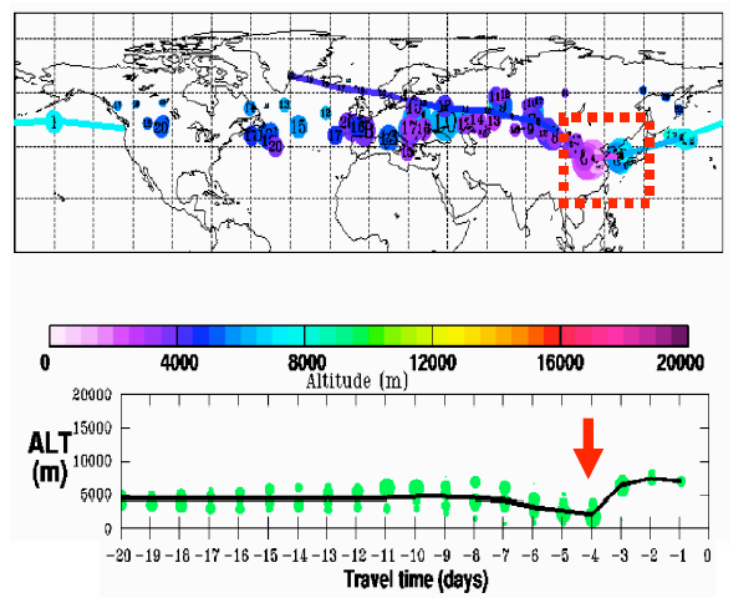

Older Asian Layer
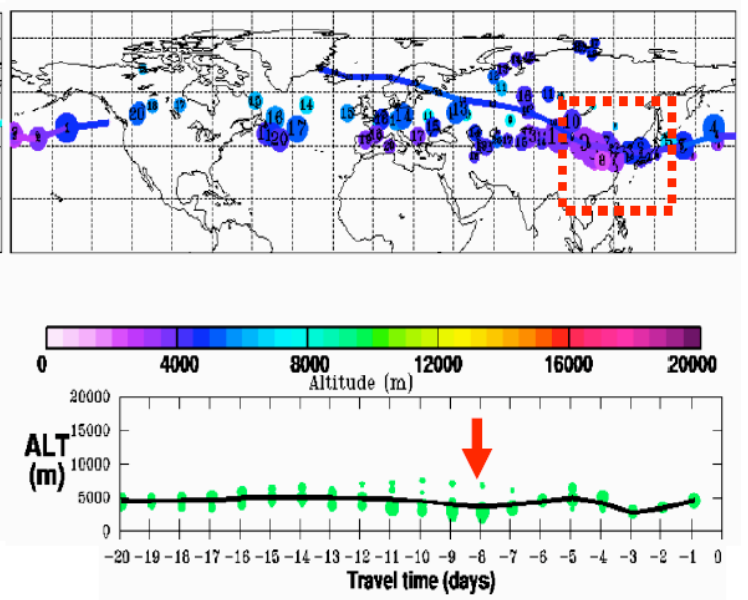

Fig. 6. FLEXPART (http://zardoz.nilu.no/ andreas/MILAGRO_ETC/index.html) back trajectories for example time periods during the Younger Asian Layer (18:44:35 to 18:46:47 UTC) on the left and the Older Asian Layer (21:13:13 to 21:14:07 UTC) on the right. Dashed boxes on the maps and arrows on the time lines indicate where back trajectories pass at lower altitudes over Asian continent. See text for discussion of these case studies. 

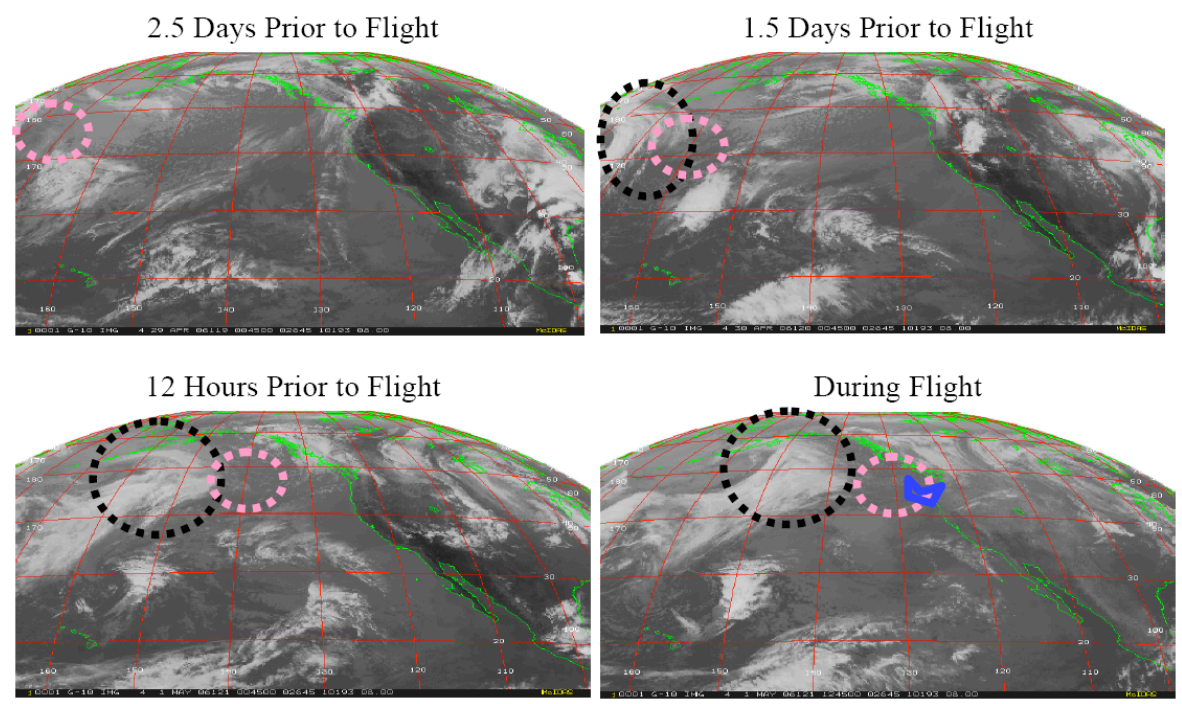

Fig. 7. Satellite imagery from GOES (http://www.goes.noaa.gov/) showing several days prior to research flight on 5/1/2006 (measurements from this flight shown in Fig. 5 above). The solid blue line is a representation of the C-130 flight track for this flight; the pink dashed circles denote the area where the Younger Asian Layer (YAL) was detected; the black dashed circles denote the cloud band ahead of which the YAL was transported.

aromatics, alkanes, alkenes, aldehydes and alcohols. The $\mathrm{NO}_{\mathrm{y}}$ within this layer was comprised primarily of PAN (60$70 \%$ ) and $\mathrm{HNO}_{3}(15-30 \%)$; this was only a slightly larger percentage of PAN than the campaign average $(55 \%)$. The $\mathrm{NO}_{\mathrm{x}} / \mathrm{NO}_{\mathrm{y}}$ ratio was slightly lower in this layer $(9 \%)$ than the campaign average (11\%), indicating that this layer does not consist of very recent emissions. Overall, the conclusion is that this layer contains Asian anthropogenic pollution that has been transported across the Pacific over the course of 3-4 days.

Further confirmation of the timescale for transport of this Asian pollution layer comes from chemical tracer data. The observed benzene to toluene $(\mathrm{B} / \mathrm{T})$ and propane to ethane $(\mathrm{P} / \mathrm{E})$ ratios in this Asian layer confirm this time scale (Parrish et al., 1992). We use starting $\mathrm{B} / \mathrm{T}(1.1)$ and $\mathrm{P} / \mathrm{E}(0.5)$ ratios from the RETRO emissions inventory (http://retro.enes. org/) for China for the sum of anthropogenic plus fire emissions. We also assume a typical 24-hour average value for the hydroxyl radical concentration, $[\mathrm{OH}]=1 \times 10^{6}$ molecule $\mathrm{cm}^{3}$ (supported by $\mathrm{OH}$ measurements on board the C-130), and an average temperature of $250 \mathrm{~K}$, which is typical for an altitude of $5 \mathrm{~km}$. Using the rate coefficients for the reactions of these aromatics with OH (Sander et al., 2006), we calculated a lifetime after emission for this pollution of 3.9 days using the $\mathrm{B} / \mathrm{T}$ ratio and 4.2 days using the $\mathrm{P} / \mathrm{E}$ ratio. Overall, it appears that this layer consists of pollution that was freshly emitted $\sim 4$ days prior and was lifted through a convective system $\sim 3$ days prior. We refer to this layer, which was sampled twice, for the rest of the paper as the "younger Asian layer" (YAL).
In order to determine the extent that this pollution layer was influenced by cloud processing, we look at convective influence modeling and chemical tracer information. Convective influence modeling as part of the back trajectory calculations shows that both intercepts of the younger Asian pollution layer were influenced by convection over the Pacific Ocean, off the coast of Asia, and not influenced by convection near North America (http://fuelberg.met.fsu. edu/research/nasa_intexb.html). Additionally, very recent washout can be excluded because the layer contains 180 400 ppt of $\mathrm{HNO}_{3}$; much lower values would be expected for an air parcel that had been recently cloud processed (Bertram et al., 2007). Lastly, the ratio of hydrogen peroxide to methyl hydrogen peroxide $\left(\mathrm{H}_{2} \mathrm{O}_{2} / \mathrm{MHP}\right)$ can be indicative of cloud processing because $\mathrm{H}_{2} \mathrm{O}_{2}$ is more water soluble than MHP (Snow et al., 2007). $\mathrm{H}_{2} \mathrm{O}_{2}$ and MHP were measured on board the C-130 (Crounse et al., 2006) and the $\mathrm{H}_{2} \mathrm{O}_{2} / \mathrm{MHP}$ ratio sharply increases in the younger Asian layer, mainly due to a decrease in the MHP mixing ratio (see Supplemental Fig. S5: http://www.atmos-chem-phys.net/9/7257/2009/ acp-9-7257-2009-supplement.pdf). This again suggests a lack of very recent cloud processing of this air mass. We conclude that this layer was likely influenced by cloud processing early in its transit across the Pacific.

The loading of submicron particles in this layer was one of the highest encountered during the entire campaign, and easily the highest encountered away from the continental US The AMS shows that the submicron composition was heavily dominated by sulfate. While there was a substantial contribution of organics as well, the ratio of sulfate/organic aerosol 

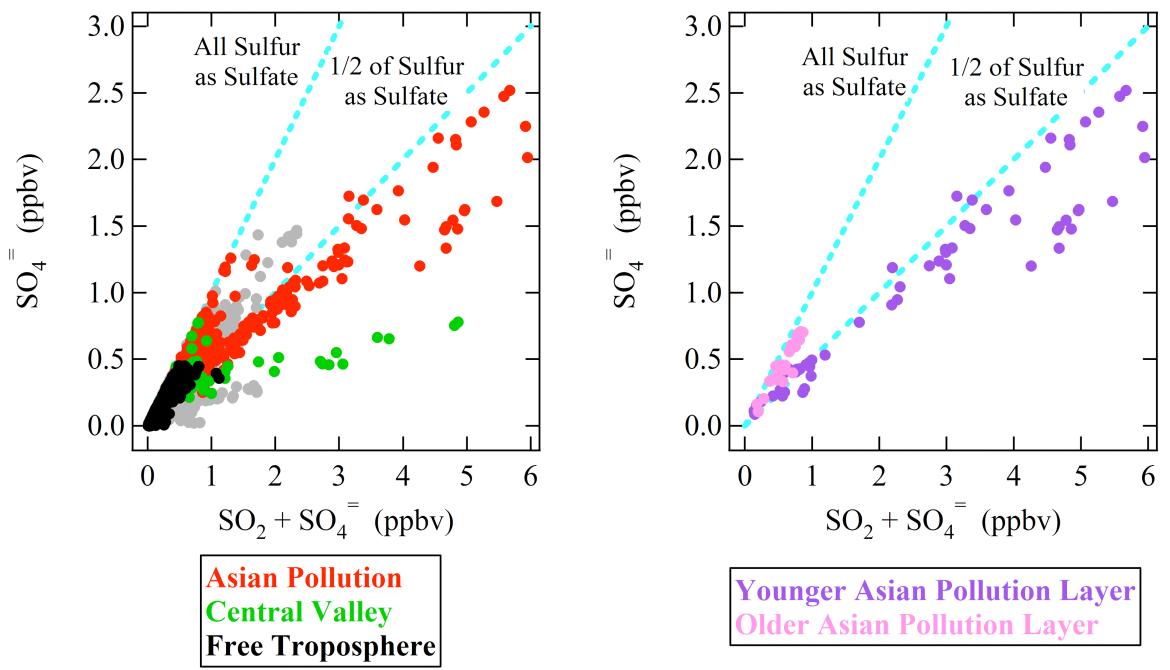

Fig. 8. Correlation plot of measured aerosol sulfate $\left(\mathrm{SO}_{4}^{=}\right)$levels converted to equivalent gas phase ppbv versus the total sulfur from the measured sulfate plus the measured gas phase $\mathrm{SO}_{2} ; 12 \mathrm{~s}$ measurements shown for all data points in left panel and only for the case studies (YAL and $\mathrm{OAL}$ ) in the right panel. There were no $\mathrm{SO}_{2}$ measurements from the Seattle flight; unclassified points are in gray.

in this layer was much larger than unity and, as such, very different than that for North American pollution over either the Central Valley of California or the Seattle region (see below). There was not a significant concentration of nitrate. The aerosol in this layer was distinctly acidic, with an average composition indicating the sulfate was in the form of $\mathrm{NH}_{4} \mathrm{HSO}_{4}$. The ratio of aerosol sulfate to total sulfur (defined as the sum of gas phase $\mathrm{SO}_{2}$ and aerosol sulfate) is approximately 0.5 for this layer; see Fig. 8 . The moderate enhancement in particle number $\left(\mathrm{CN} \sim 2000-3000 \mathrm{~cm}^{3}\right)$ observed by the CPC and the measured size distribution from the AMS show no indication that this layer contains freshly nucleated particles. The AMS sulfate size distribution is shown in Fig. 9, where the peak of the size distribution is $d_{\mathrm{va}} \sim 200 \mathrm{~nm}$ (volume equivalent diameter, $d_{\mathrm{ve}} \sim 130 \mathrm{~nm}$ ), within the accumulation mode but lower than observed for typical aged distributions at many other locations (Allan et al., 2003; Jimenez et al., 2003; Takegawa et al., 2005; Zhang et al., 2005b), including in recent Asian outflow (Fig. 9) (Bahreini et al., 2003; Topping et al., 2004), and for more aged layers in this campaign (Fig. 9). This fact, together with a tail below $100 \mathrm{~nm}$ is suggestive of new particle formation a few days prior to sampling (Zhang et al., 2004) followed by condensational growth, after scavenging of the preexisting accumulation mode during cloud processing as observed previously (Brock et al., 2004). Measurements from the SP2 instrument show very little black carbon (BC) in this layer $\left(<0.1 \mu \mathrm{g} \mathrm{sm}^{3}\right)$, suggesting that primary particles may have been mostly scavenged by the cloud processing (Brock et al., 2004). The mass spectrum of the organic aerosol in this layer shows that it is highly oxygenated in nature (see Sect. 4.3 for further discussion). Additionally, the measured mass scattering efficiency is a factor of 2-3 lower than the campaign average, consistent with the lower than typical size for the accumulation mode as discussed above.

\subsubsection{Case study of older Asian pollution layer from 5/1/2006 flight}

During this same research flight on 5/1/2006, the C-130 intercepted another pollution layer on four separate occasions between the altitudes of approximately $10000-18000 \mathrm{ft}$. It is possible that there was more than one layer present here, but all intercepts of this layer showed a consistent chemical nature and were in the same geographical location, so we refer to it as a single layer. FLEXPART back trajectory analysis shows that this layer passed over the Asian continent more than a week prior to this flight (Fig. 6). Possible convective influence on this layer cannot be gauged by any of the gas phase tracers discussed in the last section (reactive nitrogen compounds or peroxides), because those gas-phase compounds have sufficiently short lifetimes in the atmosphere that their concentrations are below their respective detection limits in this layer by the time the $\mathrm{C}-130$ sampled it. $\mathrm{The}_{\mathrm{NO}}$ loading in this layer was not significantly higher than background levels for the rest of the flight, consistent with previous studies of aged Asian pollution over the Eastern Pacific (Tang et al., 2004a). The gas phase $\mathrm{NO}_{\mathrm{y}}$ budget in this layer was very similar to both the younger Asian pollution layer and the background reactive nitrogen budget measured over the Eastern Pacific. Other tracers of the layer's Asian origin, such as MTBE and H-1211, have also become too dilute to be distinguished from the background by the instrumentation on the C-130. Although there were no distinguishable 


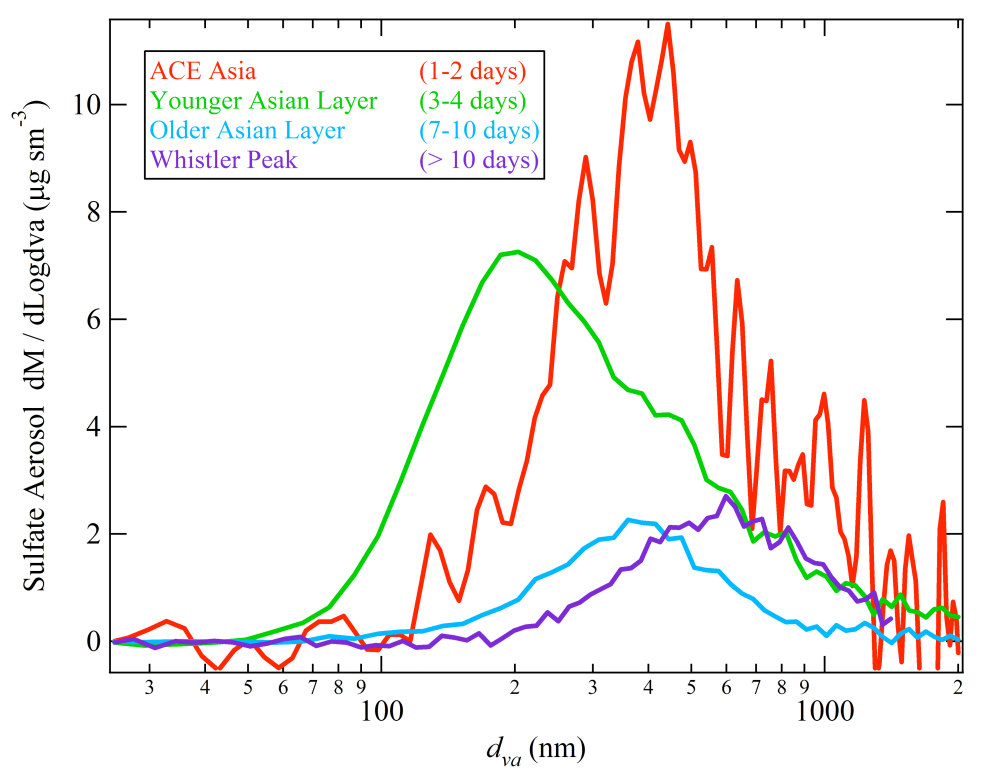

Fig. 9. Sulfate size distributions for Asian pollution layers as measured during various times of transpacific transport. ACE Asia data is from Bahreini et al. (2003), the Younger and Older Asian pollution layers are from this study and the Whistler Peak data is from an even older Asian pollution layer (>10 days old) measured atop Whistler Peak as part of the INTEX-B study (Sun et al., 2009). Transmission above $700 \mathrm{~nm}$ begins to decrease, see Fig. 1 for the transmission curves for the AMS and the inlet system. Note that there may also be some effect of slow vaporization of some larger particles that creates the appearance of more mass above a micron (i.e. the AMS transfer function is right-tailed).

enhancements of gas phase aromatic or alkane compounds, we use the average $\mathrm{B} / \mathrm{T}$ and $\mathrm{P} / \mathrm{E}$ ratios measured during this portion of the flight to roughly estimate an atmospheric lifetime for this layer. Using the same method described in the previous section and observed values in the layer for $\mathrm{B} / \mathrm{T}$ of $\sim 40$ and $\mathrm{P} / \mathrm{E}$ of $\sim 0.3$, the age of the layer is estimated to be $\sim 7$ and $\sim 9$ days, respectively from the two ratios. Based on the combination of higher sulfate concentration, back trajectory modeling, and gas-phase tracer information, we conclude that this layer originated in Asia 7-10 days prior to interception by the C-130; we refer to this layer as the "older Asian layer" (OAL) for the remainder of the paper.

In contrast to most of the gas phase tracers, enhanced aerosol mass loading and in particular the sulfate loading, was found in sufficient concentration to be detected by the AMS. This is facilitated to the longer atmospheric lifetime of particulate sulfate and the high sensitivity of the AMS. Very little black carbon, very little organic aerosol and almost no other inorganic aerosol species were measured in this layer. The ratio of aerosol sulfate to total sulfur is approximately 0.9 for this layer indicating that almost all of the gas phase $\mathrm{SO}_{2}$ has been converted to aerosol sulfate; see Fig. 8. The particle number was relatively low $\left(<500 \mathrm{~cm}^{3}\right)$ and the AMS size distribution showed a peak of $d_{\mathrm{va}} \sim 400 \mathrm{~nm}$ $\left(d_{\mathrm{ve}} \sim 225 \mathrm{~nm}\right)$, consistent with the aerosol distribution in this layer being more aged than the younger Asian layer.

We note in conclusion that the identification of pollution layers from Asia as observed over the Eastern Pacific after more than a week of processing is more difficult with the gas phase tracers traditionally used for looking at urban pollution, such as hydrocarbons or $\mathrm{NO}_{\mathrm{y}}$. However, the submicron aerosol has a longer lifetime and its chemical composition carries a signature of a high sulfate/organic aerosol ratio that persists in the atmosphere long enough ( $>1$ week) to be measured over the Eastern Pacific. This is one of a limited number of studies to observe polluted layers aged for $>1$ week in the atmosphere.

\subsection{Seattle region, central Valley and free troposphere}

Three other air mass types are defined in this section, and they serve to contrast the Asian pollution layers described in the previous section.

\section{Seattle region}

The flight pattern for research flight 03 for the C-130 on 4/24/2006 was primarily limited to various passes over the Seattle metropolitan area; most of this flight is used as the definition of the "Seattle region" air mass category. The lowest flight leg was done at an altitude of $\sim 2000 \mathrm{ft}$ $(\sim 600 \mathrm{~m})$. The vertical profiles of the potential temperature for the take-off and landings within the Seattle metropolitan area on this day show this lowest flight leg was just above the planetary boundary layer. The implication is that this air mass is more representative of the entire region around 
Seattle and not just the metropolitan area. We use the lowest measured $\mathrm{B} / \mathrm{T}$ and $\mathrm{P} / \mathrm{E}$ ratios in the Seattle region air mass in the same manner as in Sect. 3.1 to estimate an atmospheric lifetime for this Seattle region air mass category. Assuming a typical 24-h average value for $[\mathrm{OH}]=1 \times 10^{6}$ molecule $\mathrm{cm}^{3}$ (consistent with measurements onboard the C-130 during this flight) and $\mathrm{T}=270 \mathrm{~K}$ and using values for the emission ratios from the RETRO emissions inventory for the Seattle region $(\mathrm{B} / \mathrm{T}=0.32$ and $\mathrm{P} / \mathrm{E}=0.5)$ leads to lifetime estimates of $>0.9$ days and $>4$ days from the benzene/toluene ratio and propane/ethane ratio respectively. The signal to noise ratio for the propane and ethane measurements is sufficiently low that the uncertainty in this estimate is large, but it is clear that this air mass has been processed for approximately 1 day at the least; again, this air mass type is representative of the region around Seattle.

As seen in Table 3 (and Supplemental Fig. S3: http://www.atmos-chem-phys.net/9/7257/2009/

acp-9-7257-2009-supplement.pdf), this air mass type has a larger relative fraction of organics and black carbon as compared to the free tropospheric average; this is expected, given that it is primarily influenced by a North American urban center. The balance between ammonium and the sulfate and nitrate anions reveals that on average the Seattle region aerosols are close to neutralized.

\section{Central Valley}

The C-130 made two low altitude passes over the Central Valley of California during research flight 07 on 5/3/2007, generally near the Fresno and Sacramento regions; for this categorization of air masses, we define "Central Valley" as the air masses sampled during this three hour segment of this one flight. Examination of the vertical profiles of the potential temperature shows that this Central Valley air mass was contained within the planetary boundary layer. We did similar atmospheric lifetime calculations based on hydrocarbon ratios to that done in the previous sections using initial ratios from the RETRO emissions inventory for California $(\mathrm{B} / \mathrm{T}=0.37, \mathrm{P} / \mathrm{E}=0.84)$ and assumed values for the $[\mathrm{OH}]=5 \times 10^{6}$ (consistent with measurements onboard the $\mathrm{C}-130$ during this flight) and $\mathrm{T}=295 \mathrm{~K}$. These calculations give atmospheric lifetimes for this air mass of $>0.5$ days $(\mathrm{B} / \mathrm{T})$ and $>2.5$ days $(\mathrm{P} / \mathrm{E})$; these estimates are heavily dependent on the assumed starting concentration for the specific region, where the $\mathrm{B} / \mathrm{T}$ ratio is largely driven by gasoline emissions, the $\mathrm{P} / \mathrm{E}$ ratio from emissions may be more variable. We conclude that this air mass, although in the boundary layer, was not dominated by very fresh emissions, but had likely undergone at least a half a day of processing in the atmosphere. We encountered the largest total, organic, and nitrate mass concentrations of the campaign for this Central Valley air mass. The aerosol in the Central Valley is slightly acidic with an average balance of $\mathrm{NH}_{4}^{+}$ions with
$\mathrm{SO}_{4}^{=}$and $\mathrm{NO}_{3}^{-}$ions equivalent to a composition between $\mathrm{NH}_{4} \mathrm{HSO}_{4}$ and $\left(\mathrm{NH}_{4}\right)_{2} \mathrm{SO}_{4}$. Gas phase $\mathrm{HCN}$ measurements and the enhancement of $\mathrm{m} / \mathrm{z} 60$ (a biomass burning marker) in the AMS show the likely influence of biomass burning for only two short-duration plumes (less than two minutes of flight time) during the Central Valley air mass (shown in Supplemental Fig. S6: http://www.atmos-chem-phys. net/9/7257/2009/acp-9-7257-2009-supplement.pdf), so the large majority of the $\mathrm{OA}$ in this air mass does not appear to originate from $\mathrm{BB}$ sources.

\section{Free Troposphere}

In order to examine air masses that are not recently influenced by either Asian or North American urban areas, we defined a Free Troposphere category of air masses as everything sampled by the C-130 west of -125 longitude and above the marine boundary layer that had a sulfate loading of $<1 \mu \mathrm{g} \mathrm{sm}^{3}$. This background aerosol, as defined here, is also heavily influenced by sulfate, which may be the result of the category definition allowing more dilute Asian pollution layers in this category. The overall mass loadings for this category were low (Supplemental Fig. S3: http://www.atmos-chem-phys.net/9/7257/2009/ acp-9-7257-2009-supplement.pdf); the balance between ammonium and the anions, sulfate and nitrate, reveals that on average the free tropospheric aerosols are neutralized within our ability to determine this given the overall smaller mass loadings for these air mass types. This category is mainly defined to provide contrast with the other categories, and provides a limited insight into the composition of the background aerosol over the Eastern Pacific (which is still somewhat influenced by very aged and diluted Asian pollution).

\section{Discussion}

In this section we use our observations to discuss the atmospheric transformation of aerosols as they are transported from Asia across the Pacific. This is separated into the transformation of sulfate aerosol (Sect. 4.1), the transformation of organic aerosol (Sect. 4.2), and comparisons of observations with chemical transport models (Sect. 4.3).

\subsection{Atmospheric transformation of sulfate}

In Sect. 1, we described a conceptual model for the transformation of aerosol during transpacific transport described by Brock et al. (2004) and Peltier et al. (2008). In this section, we discuss our observations of sulfate in the context of this conceptual model.

Our observations from the C-130 over the Eastern Pacific during this campaign show that transported Asian pollution is heavily dominated by sulfate aerosol relative to organics 
(see Supplemental Fig. S3: http://www.atmos-chem-phys. net/9/7257/2009/acp-9-7257-2009-supplement.pdf). This is consistent with the removal of sulfate and organic aerosol near Asia followed by sulfate formation during transpacific transport. We have analyzed Asian pollution layers on multiple timescales: 3-4 days in age and 7-10 days. Additionally, observations from a ground site at Whistler Peak in British Columbia show an Asian pollution layer that had spent $>10$ days in transit (Sun et al., 2009), which is also heavily dominated by sulfate aerosol. All of these show the continued transformation of $\mathrm{SO}_{2}$ to sulfate (discussed further below) in the different aged Asian air masses without a corresponding increase in organic aerosol (OA) mass.

The measured particle mass size distributions in Fig. 9 show a decrease in the average particle diameter from a layer that was 1-2 days downwind of Asia (measured as part of ACE-Asia; Bahreini et al., 2003) to the Younger Asian Pollution layer from this study that was 3-4 days downwind of Asia. This is consistent with washout of particulate matter during lifting near Asia, followed by particle formation during transport over the Pacific (see discussion of conceptual model in Sect. 1). There is then an increase in the average particle diameter with processing time during transpacific transport for the two Asian pollution layers that are part of this study and a case study from Whistler Peak described in Sun et al. (2009) as part of INTEX-B. The loadings for the three layers from the INTEX-B study shown in Fig. 9 (Sect. 3.1 and Sun et al., 2009) are heavily dominated by sulfate with almost no nitrate or chloride, so the implication is that sulfate is the primary driver of the growth of these particles. Additionally, the AMS data show an increase in particle acidity with processing time, where the older layers show an ion balance that is more acidic than $\mathrm{NH}_{4} \mathrm{HSO}_{4}$, indicating that particles are primarily comprised of a mix of $\mathrm{NH}_{4} \mathrm{HSO}_{4}$ and $\mathrm{H}_{2} \mathrm{SO}_{4}$. We note that cloud processing is an efficient mechanism for accumulating sulfate mass for aerosols in the accumulation mode in the remote marine atmosphere (Feingold et al., 2002; Hoppel et al., 1986) but it is unclear whether this mechanism plays a role here. Overall, our conclusion is that our observations are consistent with washout of sulfate aerosol near the Asian continent followed by the conversion of $\mathrm{SO}_{2}$ to sulfate aerosol during transpacific transport leading to overall particle growth in these Asian pollution layers.

The atmospheric processing of $\mathrm{SO}_{2}$ has been studied with field observations previously, and we discuss several relevant studies here. Brock et al. (2008) observed the conversion of $\mathrm{SO}_{2}$ to sulfate over the Western Atlantic for processing times up to 3 days downwind of the urban centers in the Northeast United States. They show a 1/e lifetime for $\mathrm{SO}_{2}$ to sulfate conversion of $\sim 3.5$ days, which is based on a combination of the reaction with $\mathrm{OH}$ and cloud processing. Previous studies (Takami et al. 2007; Takiguchi et al., 2008) measured $\mathrm{SO}_{2}$ and sulfate concentrations in the China Sea and used back trajectory calculations to show that air masses reaching their measurement location had been processed for $\sim 24-55 \mathrm{~h}$. Their results indicate a 1/e lifetime for $\mathrm{SO}_{2}$ conversion $<1$ day for pollution transported from the coast of China, which is significantly faster than that for the Western Atlantic, and is likely more strongly influenced by cloud processing. Measurements from Sapporo, Japan (Kaneyasu et al., 1995) established that atmospheric processing, i.e. not sea salt, was responsible for a significant portion of the sulfate aerosol in the area. $\mathrm{SO}_{2}$ and sulfate measurements from a ground site in Tokyo, Japan (Miyakawa et al., 2007) showed that the fraction of sulfate/total sulfur varies with the season, with average values of 0.18 in summer and 0.03 in winter; this is driven mainly by the photochemical processing by the hydroxyl radical.

For Fig. 8, we calculated the aerosol sulfate in an equivalent ppbv mixing ratio and then compare this to total sulfur defined as the sum of gas phase $\mathrm{SO}_{2}$ plus aerosol sulfate. There is a trend of an increasing fraction of sulfate/total sulfur with processing time in the atmosphere: Central Valley $<$ younger Asian pollution layer $(\sim 0.5)<$ older Asian pollution layer $(\sim 0.9)$. Note, there was no $\mathrm{SO}_{2}$ data for the Seattle region flight on 4/24/2006. We plot these data points of sulfate / total sulfur as a function of atmospheric processing time in Fig. 10. For the purposes of this figure, we do not distinguish between transport age and photochemical age based on gas phase chemical clocks because the estimates for both are similar for the Asian layers in this study. The increase in sulfate fraction between the two Asian pollution layers from 0.5 to 0.9 is generally about that which would be expected for the processing of $\mathrm{SO}_{2}$ to sulfate by the gas phase reaction with $\mathrm{OH}$ over the course of several days assuming an $\mathrm{OH}$ concentration $\sim 1.5 \times 10^{6}$ molecule $\mathrm{cm}^{3}$ (based on measured $[\mathrm{OH}]$ on $\mathrm{C}-130$ ). Also in this figure, we draw a time line of the fraction of sulfate/total sulfur that corresponds to this conceptual model, showing a fast increase in the first day or so, consistent with observations near Asia (Miyakawa et al., 2007; Takami et al., 2007), followed by washout during lifting and subsequent sulfate formation. Our observations from this study are consistent with this conceptual model out to 7-10 days of processing.

There are a number of previous studies that support this conceptual model in a variety of ways. Several studies have shown the prevalence of both sulfate and organic aerosol being exported from Asia (Igarashi et al., 2006; Takegawa et al., 2006a; Wang et al., 2006). Measurements with an AMS on board the CIRPAS Twin Otter during ACE-Asia showed significant concentrations of sulfate in air masses downwind of China (Bahreini et al., 2003). The vertical transport of pollutants over Asia is known to be fast (Stohl et al., 2002) and the enhancement of total sulfur at altitudes of $2-4 \mathrm{~km}$ was observed over Asia as part of the ACE-Asia field campaign (Park et al., 2005). Cloud processing may play a role in the formation of sulfate during lofting (Jaeglé, 2007). Additionally, a recent study has shown significant scavenging of aerosol over the Western Pacific, observed for polluted air 


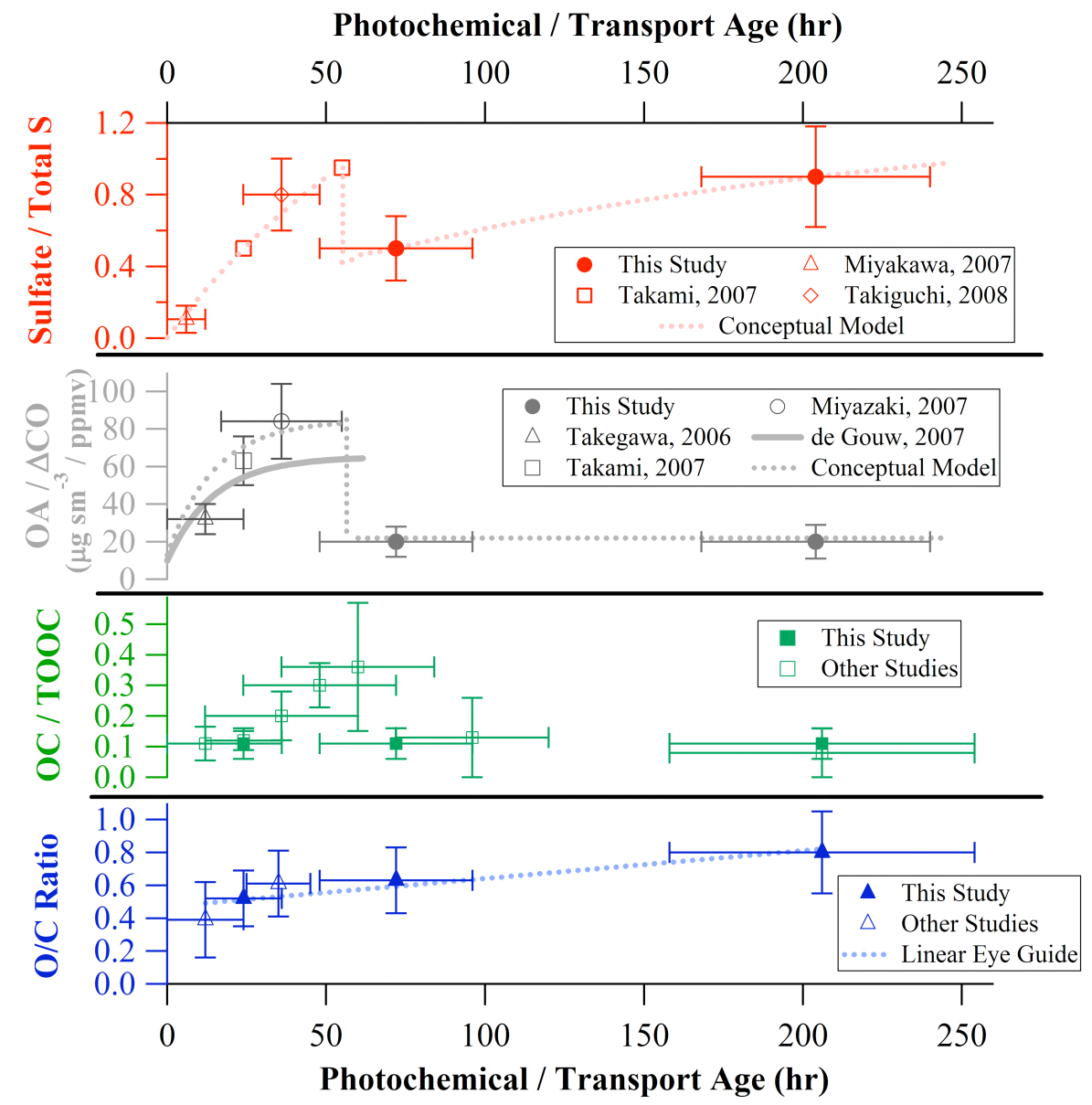

Fig. 10. Summary plot for sulfate and organic processing as a function of processing time in the atmosphere. In the top panel, the fraction of sulfate out of the total sulfur (gas phase $\mathrm{SO}_{2}+$ sulfate) is plotted for this study and several previous studies downwind of Asia (Miyakawa et al., 2007; Takami et al., 2007; Takiguchi et al., 2008). In the next panel, the ratio of organic aerosol over excess gas phase CO (CO values enhanced over background) is plotted for this study and previous studies downwind of Asia (Miyazaki et al., 2007; Takami et al., 2007; Takegawa et al., 2006b); additionally, a curve from a study off the coast of the Northeast US is shown for reference (de Gouw et al., 2008). TOOC is Total Observable Organic Carbon; see Sect. 4.2. In both cases, a sketch of the conceptual model for transpacific transport of Asian pollution described in the text is included. In the next panel, the ratio of OC/TOOC is plotted for the studies listed in Table 4. In the bottom panel, the $\mathrm{O} / \mathrm{C}$ ratios for organic aerosol for the studies listed in Table 5 are plotted along with a line to guide the eye.

masses as they are lifted into the free troposphere (Roberts, 2008). New particle formation has been observed in anthropogenic plumes advecting from Asia (McNaughton et al., 2004; Weber et al., 2003). As discussed, the observation of sulfate dominated aerosol over the Eastern Pacific was shown previously (Brock et al., 2004) and is currently reproduced by global models (Heald et al., 2006).

However, there are a few previous studies that are not consistent with this conceptual model of Asian transport. First, measurements from Mt. Bachelor (2.7 km a.s.1.) (Jaffe et al., 2005) near Bend, Oregon, have shown a prevalence of organics in transported Asian air masses, more so than sulfate, in contrast with our INTEX-B observations of Asian pollution layers (see Table 3). It is possible that other types of Asian air mass transport not sampled during INTEX-B may explain the Mt. Bachelor observations, for example an export mechanism of pollution from Asia where cloud scavenging has had a much reduced impact. We do note that these authors were unable to separate air masses classified as "marine" from those classified as "Asian". This introduces the possibility that a source of organics from the ocean which has been observed in the Northeast Pacific previously (Kaku et al., 2006) as well as elsewhere (O'Dowd et al., 2004; Spracklen et al., 2008; Vaattovaara et al., 2006), may contribute to the Jaffe et al. (2005) observations. Our observations from INTEX$\mathrm{B}$ are more definitively shown to be of Asian origin through the use of back trajectory modeling and chemical tracers for Asian, anthropogenic and marine marker compounds. 
An additional apparent discrepancy with the conceptual model comes from observations from the ACE-Asia field campaign over the Northwest Pacific in 2001 that show significant loadings of organic aerosol (OA), and high OA to sulfate ratios in the free troposphere (altitudes up to $5 \mathrm{~km}$ ) near Asia (Heald et al., 2005; Huebert et al., 2004). These observations, combined with the general consensus that air lifted to the free troposphere has undergone washout, led to the conclusion that there is large source of organics in free troposphere missing from global chemistry models (Heald et al., 2005). Average vertical profiles (Supplemental Fig. S4: http://www.atmos-chem-phys.net/9/7257/2009/ acp-9-7257-2009-supplement.pdf) of the various air mass types measured during INTEX-B reveal that most species are relatively constant with altitude over the Eastern Pacific. A ratio of organic carbon/sulfate of $\sim 5$ in the free troposphere over the Western Pacific as suggested by the ACE-Asia observations should be apparent in measurements over the Eastern Pacific, but it is not. The version of GEOS-Chem used in this study includes SOA production from isoprene photooxidation (Henze et al., 2006) that was not included in Heald et al. (2005), but that would not be enough to account for the discrepancy observed off of Asia in the Heald et al. (2005) study. Dickerson et al. (2007) recently described the different mechanisms for lifting pollution up from the Asia continent, in particular dry convection and warm conveyer belt lifting could potentially involve much reduced washout for aerosol. It is possible that the ACE-Asia organic carbon/sulfate data points represented only one type of lifting event. In summary, we observe no evidence for this large source of organics in the free troposphere over the Eastern Pacific.

Recent studies (Leaitch et al., 2009; McNaughton et al., 2009) have examined the role of dust in transpacific transport during the INTEX-B study. Our data from the C-130 indicate that for our Asian pollution category, the supermicron mode accounts for half of the total aerosol volume for $20 \%$ of the data, and accounts for a third of the total aerosol volume for $60 \%$ of data. In other words, for Asian pollution layers in this study, more than half of the data has some influence from the supermicron mode, which is presumably dust. Researchers on the DC-8 aircraft (McNaughton et al., 2009) have shown that competition between supermicrometer dust and accumulation mode aerosol for condensing secondary aerosol lead to a $25 \%$ smaller number median diameter for the accumulation mode aerosol. If we examine the size distributions in Fig. 9, we see that there is more than a factor of two reduction in the median diameter for the accumulation mode aerosol in going from aerosol near Asia to that in the YAL case study in this paper (the large mean diameter of the accumulation mode size distribution measured in ACEAsia is confirmed by other studies near Asia (Takami et al., 2005 , 2007). Alone, coagulation of accumulation mode particles with dust cannot account for large reductions in particle mean diameter seen between ACE-Asia observations and INTEX-B observations; this is best explained by washout and subsequent new particle formation as described in the Brock et al. (2004) conceptual model.

Overall, we feel that this conceptual model of Asian transport of aerosol can be viewed as a likely framework for explaining prevalent transport patterns from Asia. Yet it is clear that more definitive measurements of aerosol composition are needed in the free troposphere over the Western Pacific, specifically studying the scavenging of aerosol mass during air mass lifting.

\subsection{Atmospheric transformation of organics}

\subsubsection{Organic aerosol to carbon monoxide ratios $(\mathrm{OA} / \Delta \mathrm{CO})$}

In a similar manner to the previous section on sulfate, we now turn our attention to the atmospheric processing of organic aerosol. It has been established in several recent studies (Brock et al., 2008; Cubison et al., 2006; de Gouw et al., 2008, 2005; DeCarlo et al., 2008; Kleinman et al., 2008) that the formation of SOA downwind from urban areas proceeds with a timescale in the atmosphere on the order of 1 day. Rapid secondary organic aerosol (SOA) formation has been observed within the metropolitan area of and downwind of Tokyo (Takegawa et al., 2006a, b), and significant OA concentrations downwind of source regions in China have been observed on the Korean peninsula (Miyazaki et al., 2007) and in the East China Sea (Takami et al., 2007). As discussed in Sect. 3, there is little data from the INTEXB campaign for air masses on these shorter time scales. We put our data from the two polluted Asian layers from this study in a larger context using data from other previous studies by plotting the ratio of organic aerosol mass/excess gas phase $\mathrm{CO}(\mathrm{OA} / \Delta \mathrm{CO}$, where $\Delta \mathrm{CO}$ is $\mathrm{CO}$ minus background $\mathrm{CO}$; background $\mathrm{CO}$ values taken from average $\mathrm{CO}$ concentrations on either side of enhancements in Asian pollution layer case studies) as a function of processing time in the atmosphere in Figure 10. Previous studies from both the Northeast US (de Gouw et al., 2005) and Mexico (Kleinman et al., 2008) show the evolution of the ratio of organic aerosol mass to gas phase $\mathrm{CO}(\mathrm{OA} / \Delta \mathrm{CO})$ as a function of processing time for the first 3 days downwind of urban areas in North America, where OA/ $\triangle \mathrm{CO}$ increases over the first 1.5 days of atmospheric processing up to an asymptotic value of $\sim 65-90 \mu \mathrm{g} \mathrm{sm}^{3} \mathrm{ppmv}^{-1}$; we place a growth curve for OA/ $\triangle \mathrm{CO}$ from de Gouw et al. (2005) in Fig. 10 for reference. From our observations, both Asian pollution layer case studies in this study both have an average value for $\mathrm{OA} / \Delta \mathrm{CO}$ of $20 \mu \mathrm{g} \mathrm{sm}^{3} \mathrm{ppmv}^{-1}$, which is lower than the $\mathrm{OA} / \triangle \mathrm{CO}$ measured in Asia (Takami et al., 2007; Takegawa et al., 2006a, b). OA/ $\Delta \mathrm{CO}$ ratios from these previous studies were estimated from average and background concentrations presented in those references for $\mathrm{CO}$ (in agreement with other studies on regional CO concentrations; Kim et al., 2008) and organic mass (or organic carbon using a value of 
2.1 to convert $\mathrm{OC}$ to $\mathrm{OA}$ ), assuming no background $\mathrm{OA}$ and using an approximate correction factor of $10 \%$ to account for the conversion to OA concentrations at STP. The first conclusion that we draw from this is that significant OA formation does not occur at timescales out to $\sim 10$ days for cloudprocessed pollution plumes and the indication is that loss of OA must have occurred during the export of these pollution layers.

The assumption is that $\mathrm{OA}$ loss during transport is due to cloud scavenging, but we explore that further here. OA measured off the coast of Asia (Bahreini et al., 2003) and in this study over the Eastern Pacific (Supplemental Fig. S7: http://www.atmos-chem-phys.net/9/7257/2009/ acp-9-7257-2009-supplement.pdf) have been shown to be highly oxidized. Recent results (Huffman et al., 2009) show that highly oxidized organic aerosol is less volatile than fresher, reduced organic aerosol, such that direct evaporation of organic aerosol upon dilution is unlikely to account for a major loss of OA during transport from Asia. Additionally, field observations indicate that the timescale for significant loss of OA mass from the accumulation mode in the atmosphere due to heterogeneous processing of OA may be as slow as several months (Murphy et al., 2007); it is unlikely that this could account for the losses of OA observed in this study. One other possibility for a significant loss of submicron OA is loss on dust particles near the Asian source region (Leaitch et al., 2009), which could be important given that Asian dust transport, was substantially greater in 2006 than in previous years (Reidmiller et al., 2009), but as described in the previous section, dust is not likely to have been a major influence on the submicron aerosol in our study. We conclude that the most likely explanation for the loss of OA during transpacific transport is cloud scavenging, presumably during lifting near Asia, which preferentially removed $\mathrm{OA}$ while preserving $\mathrm{CO}$. Consistent with the sulfate processing, we draw a time line of this conceptual model for the change in the ratio of $\mathrm{OA} / \Delta \mathrm{CO}$ with processing time in Fig. 10, showing that our observations are consistent with OA formation during the first day or so of transport, washout of OA during lifting near Asia, followed by very little OA formation during the remaining transpacific transport.

Further support for the influence of washout of aerosol during transpacific transport comes from comparing of organic aerosol versus $\mathrm{O}_{\mathrm{x}}$ (the sum of $\mathrm{O}_{3}$ and $\mathrm{NO}_{2}$ ). For shorter photochemical ages the different slopes of these comparisons are indicative of the different SOA formation efficiencies in these regions, primarily due to different precursor gas mixes, and OA removal processes that have affected these air masses (Herndon et al., 2008). Supplemental Figure S8 shows that the Asian pollution layers in this study have lower ratios of $\mathrm{OA}$ to $\mathrm{O}_{\mathrm{x}}$ than other locations in this study and in other studies in Tokyo, Mexico City and Pittsburgh; is consistent with washout of OA during transport of Asian aerosols.
Table 4. Ratios of OC/TOOC for various studies; A=This study, all slopes derived from the same fit; $\mathrm{B}=$ See Heald et al. (2008) for details on other studies; uncertainty for OC/TOOC derived from $R^{2}$ value of linear correlation plot. Data presented in Fig. 10.

\begin{tabular}{llclc}
\hline Location & Study & Ref & Age (hr) & OC/TOOC \\
\hline Pittsburgh Summer & PAQS & B & $0-24$ & $0.11 \pm 0.055$ \\
Mexico City, C-130 & MILAGRO & B & $12-36$ & $0.12 \pm 0.031$ \\
Thompson Farm, N.H. & ICARTT & B & $12-60$ & $0.20 \pm 0.080$ \\
NE Atlantic, WP-3 & ICARTT & B & $24-72$ & $0.30 \pm 0.072$ \\
Chebogue Point & ICARTT & B & $36-84$ & $0.36 \pm 0.209$ \\
N Atlantic, BAe-146 & ICARTT & B & $72-120$ & $0.13 \pm 0.130$ \\
Younger Asian Layer & INTEX-B & A & $48-96$ & $0.11 \pm 0.035$ \\
Older Asian Layer & INTEX-B & A & $168-240$ & $0.11 \pm 0.035$ \\
Central Valley & INTEX-B & A & $12-36$ & $0.11 \pm 0.035$ \\
Trinidad Head & ITCT-2k2 & B & $168-240$ & $0.08 \pm 0.080$ \\
\hline
\end{tabular}

\subsubsection{Aerosol organic carbon to total observed organic carbon ratios (OC/TOOC)}

A recent study (Heald et al., 2008) has introduced the concept of Total Observed Organic Carbon (TOOC) as the sum of all measured gas phase organic species plus particle phase organic carbon (OC). In Table 4, we list the particulate OC versus TOOC for all of the studies described in (Heald et al., 2008) as an indicator of how much organic aerosol has formed compared to the maximum potential organic aerosol available in an air mass, similar to the sulfate/total sulfur ratio discussed in Sect. 4.1 (although unlike in the sulfur case, OC/TOOC never reaches 1 in practice, as many TOOC species are too volatile). Table 4 lists the slopes of these various OC/TOOC plots as well as the average OC/TOOC ratios from air masses in this study. All points from the INTEX-B campaign fall along a similar slope of $\sim 0.1$, meaning that OC comprises $\sim 10 \%$ of TOOC by mass.

If we estimate atmospheric processing ages for the various studies in Table 4 and plot the OC/TOOC ratio as a function of processing time, we see in Figure 10 that the shape of the processing profile for OC/TOOC is generally the same as that for $\mathrm{OA} / \triangle \mathrm{CO}$ and sulfate/total sulfur. Uncertainties for OC/TOOC ratios are based on the uncertainties in the linear regression fits. From the data in Heald et al. (2008), it appears that the OC/TOOC ratio has a maximum observed value in the atmosphere of $\sim 40 \%$. We note that placing all of these OC/TOOC measurements from different field campaigns on the same time line is only qualitative and very difficult to interpret further; the different regions sampled in these campaigns had widely varying mixes of organic precursor gases (both biogenic and anthropogenic), as well as having varying processing mechanisms, including different oxidizing conditions and the potential presence or absence of cloud processing, with sampling dictated by differing campaign objectives. Additionally, the TOOC value itself is inherently limited by the available suite of instrumentation deployed in 
Table 5. Oxygen-to-Carbon ratios for various studies; UMR indicates studies where Unit Mass Resolution data from the AMS was used to estimate the $\mathrm{O} / \mathrm{C}$ ratio using the ratio of signal at $\mathrm{m} / \mathrm{z} 44$ to total organic aerosol; HR indicates studies where the $\mathrm{O} / \mathrm{C}$ ratio was directly calculated from the high resolution AMS mass spectra. Uncertainties are a combination of $\mathrm{O} / \mathrm{C}$ variation during measurement period and uncertainty in $\mathrm{O} / \mathrm{C}$ ratio calculation technique (31\%) (Aiken et al., 2008)

\begin{tabular}{llllc}
\hline Location & Reference & Method & Age (hr) & O/C \\
\hline Tokyo & (Takegawa et al., 2006b) & UMR & $0-24$ & $0.39 \pm 0.23$ \\
East China Sea & (Takami et al., 2007) & UMR & $25-45$ & $0.61 \pm 0.20$ \\
Younger Asian Layer & This Study, 2008 & HR & $48-96$ & $0.63 \pm 0.20$ \\
Older Asian Layer & This Study, 2008 & HR & $158-254$ & $0.80 \pm 0.25$ \\
Central Valley & This Study, 2008 & HR & $12-36$ & $0.52 \pm 0.17$ \\
\hline
\end{tabular}

each field study. Although these differences exist, the slope in each campaign is dominated by the points with higher concentrations, which tend to be those close to the strongest sources (local or transported) that influence each geographical region. These results suggest that the OC/TOOC ratio increases with processing time in the atmosphere up until the point where washout removes a large portion of the organic aerosol, and then the OC/TOOC ratios remain low after that, dominated by long-lived organic gases. Further interpretation of the OC/TOOC time line would best be done with a consistent data set from the same region of the world, ideally with a pseudo-lagrangian study of the same air mass transported downwind of a single source region for several days.

\subsubsection{Organic aerosol mass spectra}

As expected, high-resolution mass spectra of the two Asian pollution layers show a much larger contribution from the fragment ions containing carbon, hydrogen and oxygen $\left(\mathrm{C}_{\mathrm{x}} \mathrm{H}_{\mathrm{y}} \mathrm{O}_{\mathrm{z}}^{+}\right)$compared to fragment ions containing only carbon and hydrogen $\left(\mathrm{C}_{\mathrm{x}} \mathrm{H}_{\mathrm{y}}^{+}\right)$, indicating increased aging of the OA with increased processing time in the atmosphere. This is discussed in the Supplemental Information Sect. S.2: http://www.atmos-chem-phys.net/9/7257/2009/ acp-9-7257-2009-supplement.pdf.

As a side note, we attempted to use positive matrix factorization (PMF) (Ulbrich et al., 2009) on this data set; however, we were unable to sufficiently define separate factors from within the organic aerosol mass spectra. This was owing to a combination of low overall signal levels, highly oxidized nature of the aerosol with little spectral variation, and the nature of aircraft sampling of concentrated pollution layers, where the loadings of all types of organic aerosol increase and decrease in time together making it difficult for PMF to distinguish different factors in time. No reduced aerosol (Hydrocarbon-like Organic Aerosol or HOA; Zhang et al., 2005a) was discernable.

\subsubsection{Oxygen to carbon ratios $(\mathrm{O} / \mathrm{C})$}

Lastly, we can estimate the atomic oxygen-to-carbon $(\mathrm{O} / \mathrm{C})$ ratio for the total organic aerosol in each airmass by counting individual oxygen and carbon atoms from the fragment ions in each spectrum. The method for this is described elsewhere (Aiken et al., 2007, 2008). Low signal-to-noise in the low concentration mass spectra leads to increased uncertainty in the high resolution fitting procedure and therefore in the analysis of the $\mathrm{O} / \mathrm{C}$ ratios. Averaging the mass spectra into $1 \mathrm{~min}$ time bins (up from $12 \mathrm{~s}$ ) before the $\mathrm{O} / \mathrm{C}$ ratio analysis was sufficient to reduce the uncertainty in the $\mathrm{O} / \mathrm{C}$ ratio analysis and produce a consistent result with longer averaging times. The O/C ratios for the two Asian pollution layers (Sect. 3.1) and Central Valley (Sect. 3.2) were consistent within each layer (see Fig. 5) and the average $\mathrm{O} / \mathrm{C}$ ratio values are listed in Table 5. Additionally, we include the $\mathrm{O} / \mathrm{C}$ ratios from other previous studies employing a Q-AMS; the O/C ratios can be estimated from the measured $\mathrm{m} / \mathrm{z}$ 44/total organics ratio using a relationship determined from field work with the HR-ToF-AMS in the Mexico City region (Aiken et al., 2008).

These $\mathrm{O} / \mathrm{C}$ values are plotted in Fig. 10 as a function of processing time. The $\mathrm{O} / \mathrm{C}$ ratios for the two Asian pollution layers are higher than those in most other studies, consistent with the idea that these layers are highly aged in the atmosphere; additionally, the older Asian pollution layer has a higher $\mathrm{O} / \mathrm{C}$ ratio than the younger Asian layer, consistent with the observations from the individual mass spectra described in Supplemental Sect. S2: http://www.atmos-chem-phys.net/9/7257/2009/ acp-9-7257-2009-supplement.pdf. The time trend of O/C ratios in Fig. 10 is noticeably different than the profiles of the $\mathrm{OA} / \triangle \mathrm{CO}$ or $\mathrm{OC} / \mathrm{TOOC}$ profiles; where $\mathrm{OA} / \Delta \mathrm{CO}$ and $\mathrm{OC} / \mathrm{TOOC}$ increase quickly within the first several days and decrease due to washout, the $\mathrm{O} / \mathrm{C}$ ratio continues to increase out to the time scale of a week. A linear trend line of increasing $\mathrm{O} / \mathrm{C}$ ratio with increasing processing time is included in Fig. 10 to guide the eye. The actual trend may be more exponential, but cannot be stated more definitively because, again, we are combining data from multiple locations. The 
major lesson is that although the SOA formation from pollution has nearly reached completion on the order of 1 day, the OA continues to become more oxidized through longer time scales in the atmosphere. This study provides evidence for this finding directly from atmospheric observations, and is consistent with similar results for biomass burning aerosols measured over time scales of several days over West Africa (Capes et al., 2008). This result needs to be further confirmed by additional in situ observations, ideally with observations of the same air mass at multiple times over the course of $\sim 1$ week of processing in the atmosphere.

Since the $\mathrm{OA} / \triangle \mathrm{CO}$ does not increase, this suggests that some carbon is being lost from the aerosol during this process. The continued oxidation and small loss of carbon may be due to heterogeneous reactions, which may have time scales on the order of $\sim 1$ week (Molina et al., 2004; Murphy et al., 2007; Schauer et al., 1996; Zhang et al., 2005c), or to gas-phase oxidation of semivolatile species. DeCarlo et al. (2008) recently compared the $\mathrm{O} / \mathrm{C}$ gain in photochemical aging in the first day of pollution outflow from Mexico City with what could be expected from heterogeneous oxidation and found that this mechanism was 7-135 times too slow to explain the observed gain of oxygen. This implied that the O must have been gained through SOA formation and/or reactions of semi-volatile species in the gas phase. We have done the same calculation for the addition of oxygen to the organic aerosol between the younger and older Asian layers observed here. Unlike for the results of DeCarlo et al. (2008), in our study heterogeneous oxidation with the upper limit assumptions (uptake coefficient $\gamma=1$, gain of $2 \mathrm{O}$ atoms per $\mathrm{OH}$ reaction) can produce a gain of oxygen similar to that observed in the measurements, while the lower limit assumptions ( $\gamma=0.1,1 \mathrm{O}$ added per $\mathrm{OH}$ reaction) can explain $\sim 8 \%$ of the observed $\mathrm{O}$ gain. While a significant uncertainty range remains, it is clear that heterogeneous oxidation can play a larger role for very long OA aging timescales such as those observed here than during the first day after emission of OA and SOA precursors. This is consistent with the results of the recent George et al. (2008) study where ambient particles were aged in the laboratory by $\mathrm{OH}$ oxidation.

\subsection{Comparisons with chemical transport models}

Here we compare observed tracer ratios to chemical transport model (CTM) predictions over the domain of the C-130 flight tracks. (Comparisons of observations with the Sulfur Transport and dEposition Model (STEM) model are presented elsewhere (Adhikary et al., 2009).) We focus on ensemble characteristics rather than individual plumes, which are not well resolved at the coarse $(\sim 200 \mathrm{~km})$ CTM resolution and which may be displaced geographically in the model owing to uncertainty in the meteorological fields. Figure 11 shows the correlations of organic aerosol versus sulfate aerosol for the AMS measurements from the C-130 at two time resolutions (12 $\mathrm{s}$ and $15 \mathrm{~min}$ ), and for the MOZART and GEOS-Chem model outputs (15 min). Figure 12 shows the same correlations for organic aerosol from the AMS versus gas phase $\mathrm{CO}$. Air mass categories for the models were defined as the same time periods as those from the measurements.

This is the first attempt of which we are aware to use aerosol data to do this kind of tracer-tracer correlation. This has been done with gas phase species previously (see Parrish et al., 2004, for example), but aerosol chemical composition instrumentation with sufficient time resolution has not been deployed on aircraft until recently. The high time resolution data (12 s) provided by the AMS in Figs. 11 and 12 show features that are not evident when the AMS data is averaged to a much lower time resolution of $15 \mathrm{~min}$.

We briefly comment here on several overall trends. First, the ratios of $\mathrm{SO}_{4}^{=} /\left(\mathrm{SO}_{2}+\mathrm{SO}_{4}^{=}\right)$can be interpreted as a qualitative photochemical/processing age of the sulfur species, and are generally captured well by both models (measurements shown in Fig. 8, model results shown in Supplemental Fig. S9: http://www.atmos-chem-phys.net/9/7257/2009/ acp-9-7257-2009-supplement.pdf). As expected, they show lower values for the Central Valley than for Asian pollution due to the longer processing times for the Asian pollution layers.

Next, ratios of organic aerosol/sulfate provide insights on the relative strengths of the emissions of both precursors and POA, and the efficiency of SOA formation. MOZART generally shows less organics relative to sulfate when compared to the measurements, while GEOS-Chem shows more similar and even higher ratios than the observations. The modeled ratios of organic aerosol/sulfate for the various air mass types are mostly qualitatively correct in comparison to each other, i.e. the Central Valley organic aerosol/sulfate ratio is larger than that for Asian pollution layers. It is noted that the MOZART Seattle region values for organic aerosol/sulfate show about the same slope as the measurements (Fig. 12), while MOZART shows significantly lower ratios for the Central Valley. This is likely due to the higher fraction of POA in the Seattle area, as indicated with the lower OA/BC ratio, which is better captured by MOZART than SOA.

Several recent studies have reported good correlations of total organic mass with excess $\mathrm{CO}$ (CO minus background CO) (DeCarlo et al., 2008; Kleinman et al., 2008), and ratios of these species have been used to quantify POA emissions and assess the efficiency of SOA formation. Ratios of the order of $2-10 \mu \mathrm{g} \mathrm{sm}^{-3} \mathrm{ppm}^{-1}$ are typical of traffic/urban combustion emissions in the US (Docherty et al., 2008; Zhang et al., 2005c), while higher ratios can be due to SOA formation and/or biomass burning (de Gouw et al., 2008; DeCarlo et al., 2008; Kleinman et al., 2008). The C-130 measurements show very high ratios for the Central Valley indicative of extensive SOA formation, while the values for the Asian pollution layers are relatively low, again consistent with scavenging of much of the SOA formed over Asia upon cloud processing (Brock et al., 2004). For the 

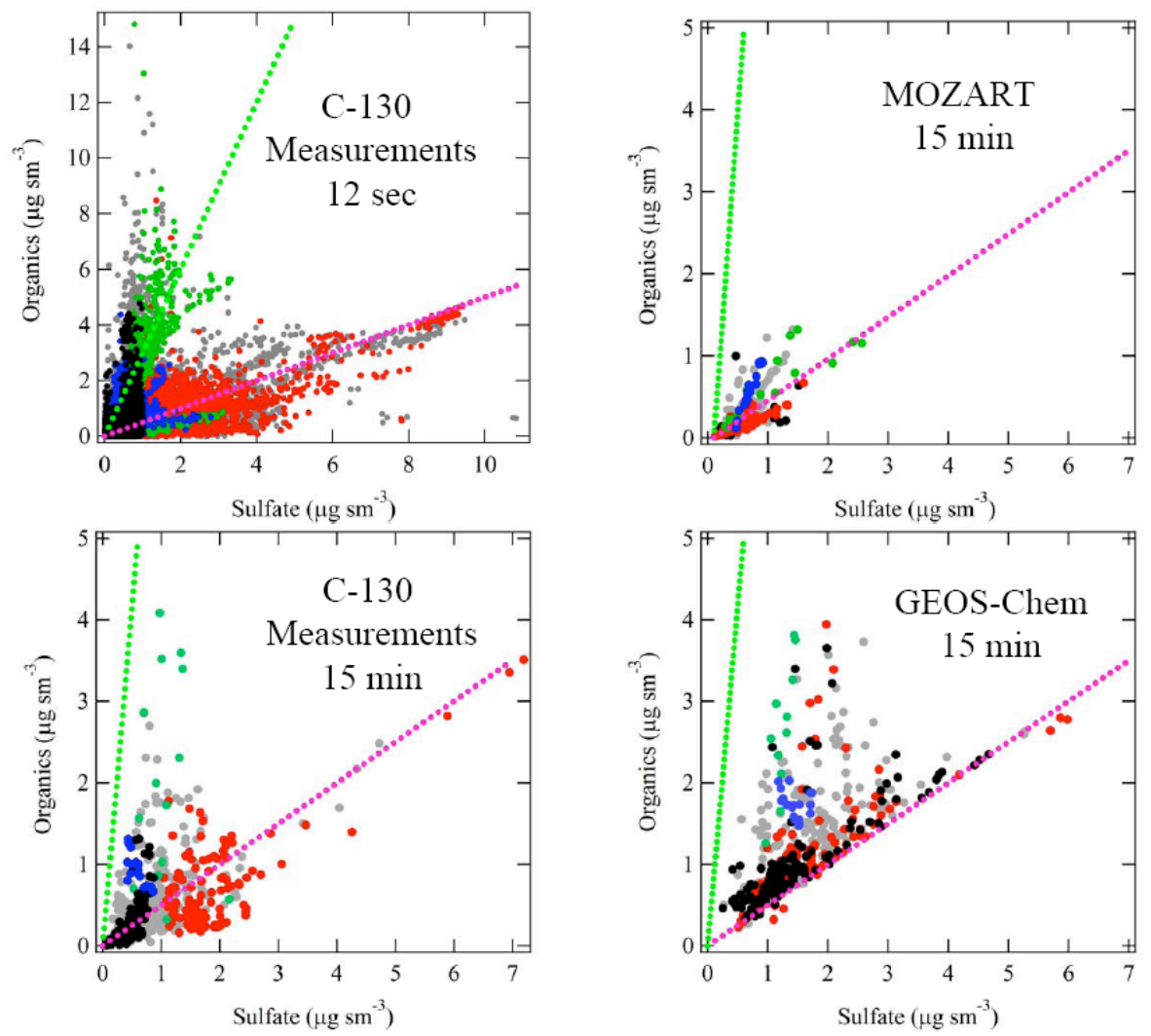

Central Valley Seattle Free Troposphere Asian Pollution

Fig. 11. Scatter plots of organic aerosol mass versus sulfate aerosol mass for AMS measurements on board the C-130 and the MOZART and GEOS-Chem chemical transport models for the entire INTEX-B campaign. The chemical transport model points are classified based on the measurement classification for the same time during the flight. For the Central Valley, the green dashed line shows a slope of 3:1, based on a large mode of Central Valley 12-s data points that are centered around that line; similarly, the pink dashed line shows a slope of 1:2 based on the Asian pollution 12-s data points. (No fit is shown for the Seattle or free troposphere data.) The same lines are shown in all 4 plots for comparison. Unclassified points are in gray.

ratios of $\mathrm{OA} / \triangle \mathrm{CO}$, GEOS-Chem generally shows higher ratios and MOZART generally shows lower ratios compared to measurements. The MOZART OA/ $\triangle \mathrm{CO}$ ratios are very low for the Central Valley air masses, likely due to SOA formation that is too low in the model. All three sets of data span a similar range of OA concentrations $(0-$ $4 \mu \mathrm{g} \mathrm{sm}^{-3}$, for 15 -min averages), but the $\mathrm{CO}$ ranges are very different, with GEOS-Chem clearly lower than the measurements while MOZART is more similar. This may be due to an overestimation of the $\mathrm{OH}$ concentration by GEOSChem (Zhang et al., 2008) (see Fig. 12 and Supplemental Figs. S10 and S11: http://www.atmos-chem-phys.net/9/ 7257/2009/acp-9-7257-2009-supplement.pdf) and may suggest that the SOA formation mechanisms may be much more efficient in GEOS-Chem than in MOZART.

Figure 13 shows the vertical profiles of modeled values from GEOS-Chem and MOZART for aerosol OC and sulfate compared with the measurements from the AMS on board the C-130 aircraft for Asian pollution layers (with
OC estimated as OA/2.1). In general, MOZART predicts lower OC and sulfate concentrations than were measured and GEOS-Chem slightly over-predicts the amount of OC. It is noted that the discrepancies shown here are significantly less than those determined for measurements made from aircraft over the Western Pacific during ACE-Asia (Heald et al., 2005). Overall the model/measurement comparison is complex, but only MOZART shows a clear underestimation of organics. This is distinguished from previous studies over the Western Pacific where large discrepancies between GEOSChem and aircraft measurements of OC were reported (Heald et al., 2005).

\section{Conclusions}

In conclusion, in this study we have described the deployment of a HR-ToF-AMS on board the C-130 aircraft during the INTEX-B field campaign over the Northeast Pacific in 

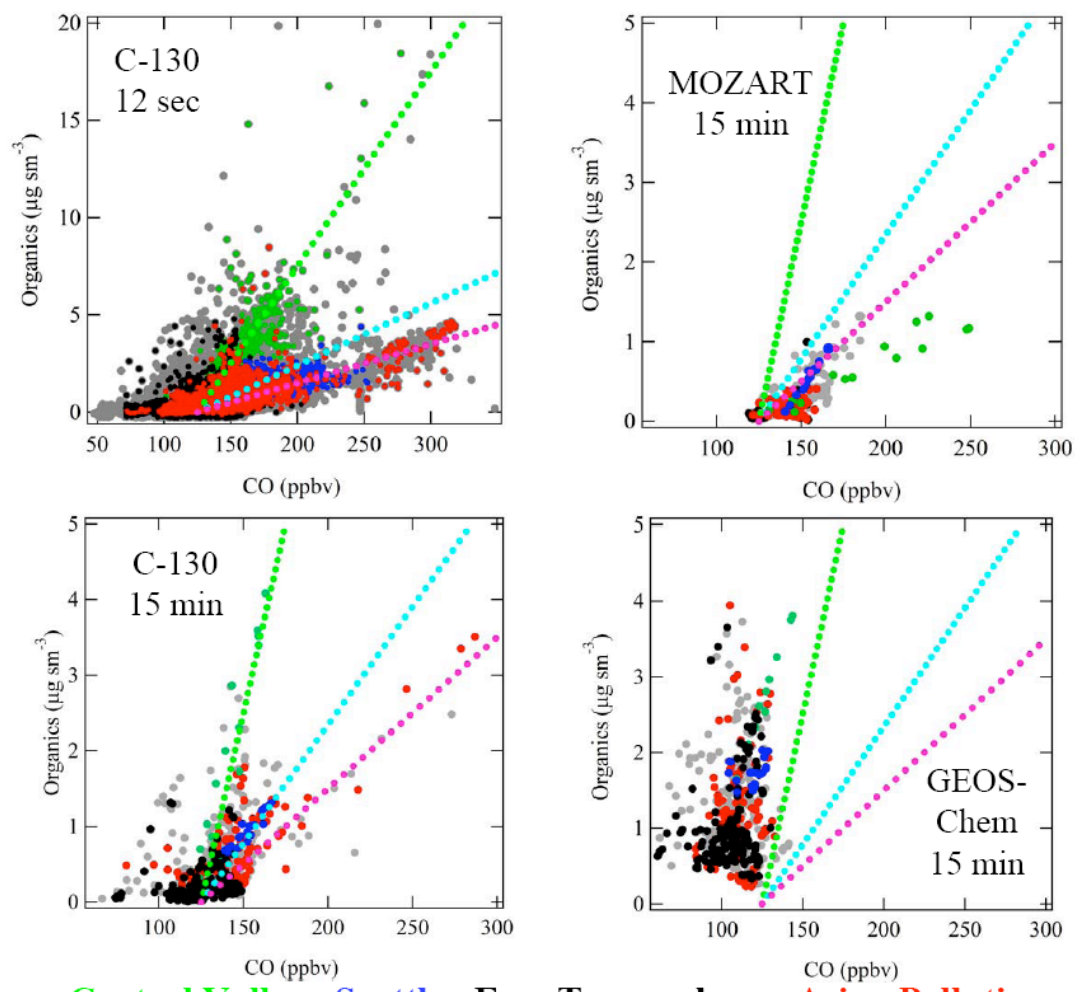

Central Valley Seattle Free Troposphere Asian Pollution

Fig. 12. Similar to Fig. 11 above, scatter plots of organic aerosol mass versus gas phase $\mathrm{CO}$ for the same measurements and models as in the upper panel. Dashed lines indicate linear fitted slopes derived from the 12-s AMS measurements on the C130; the green dashed line indicates the linear fit (slope $=100 \mu \mathrm{g} \mathrm{sm}^{3} \mathrm{ppm}^{1}$ ) to the Central Valley data points, the light blue line is for Seattle region $\left(\mathrm{slope}=32 \mu \mathrm{g} \mathrm{sm}{ }^{3} \mathrm{ppm}^{1}\right)$ and the pink dashed line is for the Asian pollution layers (slope $=20 \mu \mathrm{g} \mathrm{sm}^{3} \mathrm{ppm}^{1}$ ); the same lines are shown in all 4 plots in the lower panel.

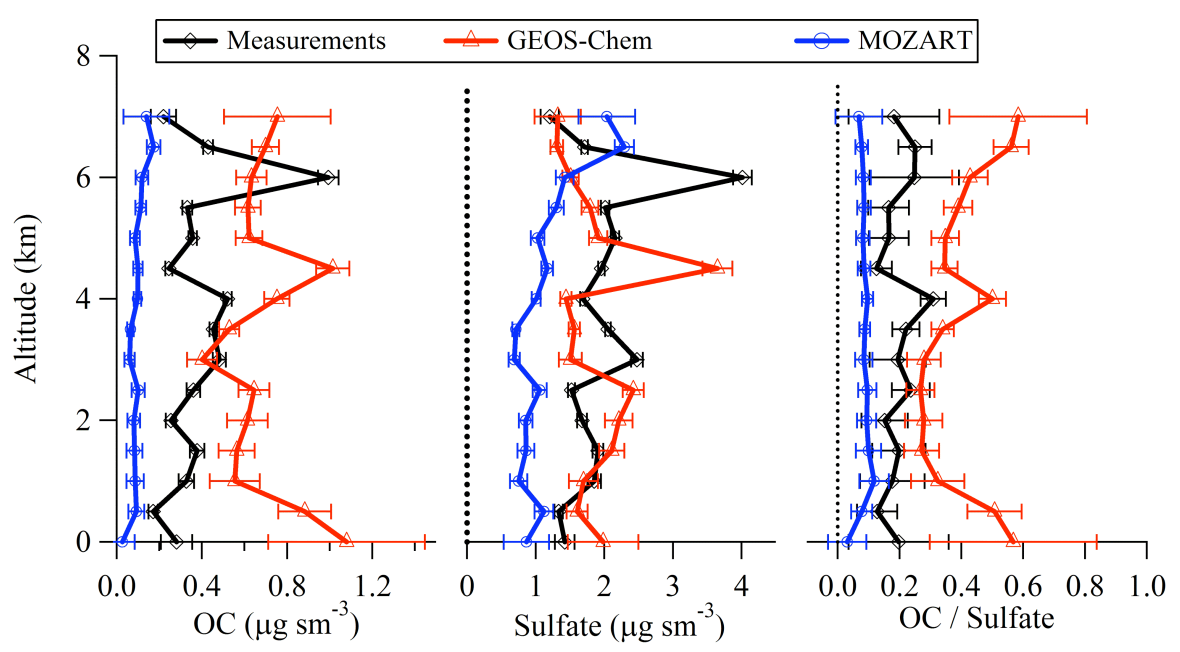

Fig. 13. Average vertical profiles of aerosol species for Asian pollution layers measured during the INTEX-B campaign for measurements from the AMS from the C-130 aircraft and modeled values for the C-130 flight tracks from the GEOS-Chem and MOZART chemical transport models. The OC signal from the AMS was derived form the AMS organic mass divided by 2. Uncertainties shown are one standard deviation for the standard error resulting from the averaging with $0.5 \mathrm{~km}$ altitude bins. 
the spring of 2006. Comparisons amongst several submicron aerosol instruments on board the C-130 and with instruments on board the DC-8 during intercomparison flights show generally good agreement indicating that there were no significant losses for any of the aerosol inlets used. The measurements of aerosol chemical composition from the AMS were used to describe several air mass types ("Asian pollution layers", "Seattle region", "Central Valley", and "free troposphere").

We have provided further evidence to support the conceptual model for the transpacific transport of Asian aerosols in the free troposphere put forth by Brock et al. (2004). This involves the relatively faster processing of gas phase organic precursors to form organic aerosol compared to the processing of gas phase $\mathrm{SO}_{2}$ to form sulfate aerosol. The subsequent washout of aerosol during the lifting of Asian air masses out of the boundary layer, which is the first step for rapid transport across the Pacific, leaves the air mass relatively enhanced in gas phase $\mathrm{SO}_{2}$ compared to gas phase organic precursors. Subsequent processing during transport yields a larger sulfate aerosol than organic aerosol, which is what was observed in this study over the Eastern Pacific. The end result is similar to the conclusion by Brock et al. (2008) that over the oceans, sulfate determines the aerosol mass loading because of the potential sulfate, i.e. $\mathrm{SO}_{2}$, available as the polluted air mass moves off shore, while the SOA precursors have been mostly depleted. Our observations show the increased fraction of sulfate compared to total sulfur and increased sulfate particle size distribution with increasing age in the atmosphere. This implies a general pattern of sulfate dominated aerosol over much of the Pacific because of the continual transport of Asian pollution eastward over the $\mathrm{Pa}-$ cific.

Our measurements of Asian pollution layers are some of the first at atmospheric processing timescales of $>1$ week. Enhancements of gas phase compounds present in younger Asian pollution layers are not detectable in layers that have been aged for a week or longer. However, aerosol sulfate concentrations are still present in detectable levels in layers as old as 7-10 days, indicating that aerosol chemistry serves as a robust tracer of Asian pollution for these longer time scales.

Our observations of the processing times of organic aerosol in the atmosphere are generally consistent with the conclusion that organic aerosol formation takes place within the time frame of $\sim 1$ day. In contrast, our measurements are the first to show the continued oxidation of organic aerosol through one week of atmospheric processing directly from in-situ observations.

Two of the largest discrepancies found in comparing our AMS measurements with two chemical transport models, MOZART and GEOS-Chem, are an overall under-prediction of organic aerosol by MOZART and an over-prediction of CO by GEOS-Chem. Our observations over the Eastern Pacific show no evidence for the large source of organics in the free troposphere proposed in earlier studies (Heald et al., 2005).

Acknowledgements. We thank the following people for helpful discussions and/or providing data or model products: Roya Bahreini, Darrel Baumgardner, Teresa Campos, John Crounse, Frank Flocke, Henry Fuelberg, David Knapp, Ann Middlebrook, Denise Montzka, Michael Porter, Gregory Roberts, R. Subramanian, Ingrid Ulbrich, Andrew Weinheimer, Paul Wennberg, Qi Zhang. We would also like to thank the crew of the NSF/NCAR C-130 aircraft, especially William Irwin, Mark Lord, Pavel Romashkin, and Allen Schanot. This study was supported by NASA grants NNG06GB03G, NNG06GB27G and NNG04GA67G, and by NSF grant ATM 0513116, and NSF/UCAR grant S05-39607. ACA and PDF are grateful for graduate fellowships from NASA and EPA respectively (NNG04GR06H and FP-91650801). The National Center for Atmospheric Research is sponsored by the National Science Foundation.

Edited by: H. Singh

\section{References}

Adhikary, B., Carmichael, G. R., Kulkarni, S., Wei, C., Tang, Y., Dallura, A., Mena-Carrasco, M., Streets, D. G., Zhang, Q., Pierce, R. B., Al-Saadi, J. A., Emmons, L. K., Pfister, G. G., Avery, M. A., Barrick, J. D., Blake, D. R., Brune, W. H., Cohen, R. C., Dibb, J. E., Fried, A., Heikes, B. G., Huey, L. G., O’Sullivan, D. W., Sachse, G. W., Shetter, R. E., Singh, H. B., Campos, T. L., Cantrell, C. A., Flocke, F. M., Dunlea, E. J., Jimenez, J. L., Weinheimer, A. J., Crounse, J. D., Wennberg, P. O., Schauer, J. J., Stone, E. A., Jaffe, D. A., and Reidmiller, D. R.: Trans-Pacific transport and evolution of aerosols and trace gases from Asia during the INTEX-B field campaign, Atmos. Chem. Phys. Discuss., 9, 16381-16439, 2009,

http://www.atmos-chem-phys-discuss.net/9/16381/2009/.

Aiken, A. C., DeCarlo, P. F., and Jimenez, J. L.: Elemental Analysis of Organic Species with Electron Ionization HighResolution Mass Spectrometry, Anal. Chem., 79, 8350-8358, doi:10.1021/ac071150w, 2007.

Aiken, A. C., DeCarlo, P. F., Kroll, J. H., Worsnop, D. R., Huffman, J. A., Docherty, K., Ulbrich, I. M., Mohr, C., Kimmel, J. R., Sueper, D., Sun, Y., Zhang, Q., Trimborn, A., Northway, M., Ziemann, P. J., Canagaratna, M. R., Alfarra, M. R., Prevot, A. S. H., Dommen, J., Duplissy, J., Metzger, A., Baltensperger, U., and Jimenez, J. L.: O/C and OM/OC Ratios of Primary, Secondary, and Ambient Organic Aerosols with High Resolution Time-ofFlight Aerosol Mass Spectrometry, Environ. Sci. Technol., 42, 4478-4485, doi:10.1021/es703009q, 2008.

Allan, J. D., Alfarra, M. R., Bower, K. N., Williams, P. I., Gallagher, M. W., Jimenez, J. L., McDonald, A. G., Nemitz, E., Canagaratna, M. R., Jayne, J. T., Coe, H., and Worsnop, D. R.: Quantitative sampling using an Aerodyne Aerosol Mass Spectrometer, Part 2: Measurements of fine particulate chemical composition in two UK Cities, J. Geophys. Res.-Atmos., 108(D3), 4091, doi:10.1029/2002JD002359, 2003.

Anderson, T. L., Covert, D. S., Marshall, S. F., Laucks, M. L., Charlson, R. J., Waggoner, A. P., Ogren, J. A., Caldow, R., Holm, R. L., Quant, F. R., Sem, G. J., Wiedensohler, A., 
Ahlquist, N. A., and Bates, T. S.: Performance characteristics of a high-sensitivity, three wavelength, total scatter/backscatter nephelometer, J. Atmos. Ocean. Tech., 13, 967-986, 1996.

Anderson, T. L., Masonis, S. J., Covert, D. S., Ahlquist, N. C., Howell, S. G., Clarke, A. D., and McNaughton, C. S.: Variability of aerosol optical properties derived from in situ aircraft measurements during ACE-Asia, J. Geophys. Res., 108, 8647, doi:8610.1029/2002JD003247, 2003.

Andreae, M. O., Berresheim, H., Andreae, T. W., Kritz, M. A., and Merrill, J. T.: Vertical Distribution of Dimethylsulfide, Sulfur Dioxide, Aerosol Ions, and Radon over the Northeast Pacific Ocean, J. Atmos. Chem., 6, 149-173, 1988.

Apel, E. C., Hills, A. J., Lueb, R., Zindel, S., Eisele, S., and Riemer, D. D.: A fast-GC/MS system to measure $C_{2}$ to $C_{4}$ carbonyls and methanol aboard aircraft, J. Geophys. Res., 108(D20), 8794, doi:10.1029/2002JD003199, 2003.

Auvray, M. and Bey, I.: Long-range transport to Europe: Seasonal variations and implications for the European ozone budget, J. Geophys. Res., 110, D11303, doi:10.1029/2004JD005503, 2005.

Bahreini, R., Dunlea, E. J., Matthew, B. M., Simons, C., Docherty, K. S., DeCarlo, P. F., Brock, C. A., Jimenez, J. L., and Middlebrook, A. M.: Design and Operation of a Pressure Controlled Inlet for Airborne Sampling with an Aerodynamic Aerosol Lens, Aerosol Sci. Tech., 42(6), 465-471, doi:10.1080/02786820802178514, 2008.

Bahreini, R., Jimenez, J. L., Wang, J., Flagan, R. C., Seinfeld, J. H., Jayne, J. T., and Worsnop, D. R.: Aircraft-based aerosol size and composition measurements during ACE-Asia using an Aerodyne aerosol mass spectrometer, J. Geophys. Res.-Atmos., 108(D23), 8645, doi:10.1029/2002JD003226, 2003.

Baker, A. K., Beyersdorf, A. J., Doezem, L. A., Katzenstein, A., Meinardi, S., Simpson, I. J., Blake, D. R., and Rowland, F. S.: Measurements of nonmethane hydrocarbons in 28 United States cities, Atmos. Environ., 42(1), 170-182, 2007.

Barletta, B., Meinardi, S., Simpson, I. J., Rowland, F. S., Chan, C.-Y., Wang, X., Zou, S., Chan, L. Y., Blake, D. R.: Ambient halocarbon mixing ratios in 45 Chinese cities, Atmos. Environ., 40, 7706-7719, 2006.

Baron, P. A. and Willeke, K.,: Aerosol Measurement: Principles Techniques, and Applications, Wiley-InterScience, Inc.: 2001.

Bell, N., Hsu, L., Jacob, D. J., Schultz, M. G., Blake, D. R., Butler, J. H., King, D. B., Lobert, J. M., and Maier-Reimer, E.: Methyl iodide: Atmospheric budget and use as a tracer of marine convection in global models, J. Geophys. Res., 107(D17), 4340, doi:10.1029/2001JD001151, 2002.

Benkovitz, C. M., Schwartz, S. E., Jensen, M. P., and Miller, M. A.: Attribution of modeled atmospheric sulfate and $\mathrm{SO}_{2}$ in the Northern Hemisphere for June-July 1997, Atmos. Chem. Phys., 6, 4723-4738, 2006, http://www.atmos-chem-phys.net/6/4723/2006/.

Berntsen, T. K., Karlsdottir, S., and Jaffe, D. A.: Influence of Asian emissions on the composition of air reaching the North Western United States, Geophys. Res. Lett., 26, 2171-2174, 1999.

Bertram, T. H., Perring, A. E., Wooldridge, P. J., Crounse, J. D., Kwan, A. J., Wennberg, P. O., Scheuer, E., Dibb, J., Avery, M., Sachse, G., Vay, S. A., Crawford, J. H., McNaughton, C. S., Clarke, A., Pickering, K. E., Fuelberg, H., Huey, G., Blake, D. R., Singh, H. B., Hall, S. R., Shetter, R. E., Fried, A., Heikes, B. G., and Cohen, R. C.: Direct Measurements of the Convective
Recycling of the Upper Troposphere, Science, 315, 816, 2007.

Bey, I., Jacob, D. J., Yantosca, R. M., Logan, J. A., Field, B. D., Fiore, A. M., Li, Q. B., Liu, H. G. Y., Mickley, L. J., and Schultz, M. G.: Global modeling of tropospheric chemistry with assimilated meteorology: Model description and evaluation, J. Geophys. Res., 106, 23073-23095, 2001.

Bonard, A., Daele, V., Delfau, J.-L., and Vovelle, C.: Kinetics of OH Radical Reactions with Methane in the Temperature Range 295-660 K and with Dimethyl Ether and Methyl-tert-butyl Ether in the Temperature Range 295-618 K, J. Phys. Chem. A, 106, 4384-4389, 2002.

Bond, T. C. and Bergstrom, R. W.: Light Absorption by Carbonaceous Particles: An Investigative Review, Aerosol Sci. Tech., 40, 27-67, 2006.

Brock, C. A., Hudson, P. K., Lovejoy, E. R., Sullivan, A., Nowak, J. B., Huey, L. G., Cooper, O. R., Cziczo, D. J., Gouw, J. D., Fehsenfeld, F. C., Holloway, J. S., Hubler, G., Lafleur, B. G., Murphy, D. M., Neuman Jr., J. A., Orsini, D. A., Parrish, D. D., Ryerson, T. B., Tanner, D. J., Warneke, C., Weber, R. J., and Wilson, J. C.: Particle characteristics following cloud-modified transport from Asia to North America, J. Geophys Res., 109, D23S26, doi:10.1029/2003JD004198, 2004.

Brock, C. A., Sullivan, A. P., Peltier, R. E., Weber, R. J., Wollny, A., Gouw, J. A. D., Middlebrook, A. M., Atlas, E. L., Stohl, A., Trainer, M. K., Cooper, O. R., Fehsenfeld, F. C., Frost, G. J., Holloway, J. S., Hübler, G., Neuman, J. A., Ryerson, T. B., Warneke, C., and Wilson, J. C.: Sources of Particulate Matter in the Northeastern United States: 2, Evolution of Chemical and Microphysical Properties, J. Geophys. Res., 113, D08302, doi:10.1029/2007JD009241, 2008.

Bytnerowicz, A. and Fenn, M. E.: Nitrogen deposition in California forests: A review, Environ. Pollut., 92(2), 127-146, 1996.

Cahill, C. F.: Asian aerosol transport to Alaska during ACE-Asia, J. Geophys. Res., 108(D23), 8664, doi:10.1029/2002JD003271, 2003.

Canagaratna, M. R., Jayne, J. T., Jimenez, J. L., Allan, J. D., Alfarra, M. R., Zhang, Q., Onasch, T. B., Drewnick, F., Coe, H., Middlebrook, A., Delia, A., Williams, L. R., Trimborn, A. M., Northway, M. J., DeCarlo, P. F., Kolb, C. E., Davidovits, P., and Worsnop, D. R.: Chemical and Microphysical Characterization of Ambient Aerosols with the Aerodyne Aerosol Mass Spectrometer, Mass Spectrom. Rev., 26, 185-222, 2007.

Capes, G., Johnson, B., McFiggans, G., Williams, P. I., Haywood, J., and Coe, H.: Aging of biomass burning aerosols over West Africa: Aircraft measurements of chemical composition, microphysical properties, and emission ratios, J. Geophys. Res., 113, D00C15, doi:10.1029/2008JD009845, 2008.

Chin, Mian, Diehl, T., Ginoux, P., and Malm, W.: Intercontinental transport of pollution and dust aerosols: implications for regional air quality, Atmos. Chem. Phys., 7, 5501-5517, 2007, http://www.atmos-chem-phys.net/7/5501/2007/.

Chung, S. H. and Seinfeld, J. H.: Global distribution and climate forcing of carbonaceous aerosols, J. Geophys. Res.-Atmos., 107(D19), 4407, doi:10.1029/2001JD001397, 2002.

Cooper, O. R., Forster, C., Parrish, D., Trainer, M., Dunlea, E., Ryerson, T., Hubler, G., Fehsenfeld, F., Nicks, D., Holloway, J., Gouw, J. D., Warneke, C., Roberts, J. M., Flocke, F., and Moody, J.: A case study of transpacific warm conveyor belt transport: Influence of merging airstreams on trace 
gas import to North America, J. Geophys. Res., 109, D23S08, doi:10.1029/2003JD003624, 2004.

Cross, E. S., Slowik, J. G., Davidovits, P., Allan, J. D., Worsnop, D. R., Jayne, J. T., Lewis, D. K., Canagaratna, M., and Onasch, T. B.: Laboratory and ambient particle density determinations using light scattering in conjunction with aerosol mass spectrometry, Aerosol Sci. Tech., 41, 343-359, 2007.

Crounse, J. D., McKinney, K. A., Kwan, A. J., and Wennberg, P. O.: Measurement of gas-phase hydroperoxides by chemical ionization mass spectrometry, Anal. Chem., 78, 6726-6732, 2006.

Cubison, M. J., Alfarra, M. R., Allan, J., Bower, K. N., Coe, H., McFiggans, G. B., Whitehead, J. D., Williams, P. I., Zhang, Q., Jimenez, J. L., Hopkins, J., and Lee, J.: The characterisation of pollution aerosol in a changing photochemical environment, Atmos. Chem. Phys., 6, 5573-5588, 2006,

http://www.atmos-chem-phys.net/6/5573/2006/.

d'Almeida, G. A., Koepke, P., and Shettle, E. P.:Atmospheric Aerosols: Global Climatology and Radiative Characteristics, A, Deepak Pub.: Hampton, Va., USA, 1991.

Day, D. A., Takahama, S., Gilardoni, S., and Russell, L. M.: Organic composition of single and submicron particles in different regions of western North America and the eastern Pacific during INTEX-B 2006, Atmos. Chem. Phys., 9, 5433-5446, 2009, http://www.atmos-chem-phys.net/9/5433/2009/.

de Gouw, J., Brock, C. A., Atlas, E. L., Bates, T. S., Fehsenfeld, F. C., Goldan, P. D., Holloway, J. S., Kuster, W. C., Lerner, B. M., Matthew, B. M., Middlebrook, A. M., Onasch, T. B., Peltier, R. E., Quinn, P. K., Senff, C. J., Stohl, A., Sullivan, A. P., Trainer, M., Warneke, C., Weber, R. J., and Williams, E. J.: Sources of particulate matter in the northeastern United States in summer: 1, Direct emissions and secondary formation of orgainc matter in urban plumes, J. Geophys. Res., 113, D08301, doi:10.1029/2007JD009243, 2008.

de Gouw, J. A., Middlebrook, A. M., Warneke, C., Goldan, P. D., Kuster, W. C., Roberts, J. M., Fehsenfeld, F. C., Worsnop, D. R., Canagaratna, M. R., Pszenny, A. A. P., Keene, W. C., Marchewka, M., Bertman, S. B., and Bates, T. S.: Budget of organic carbon in a polluted atmosphere: Results from the New England Air Quality Study in 2002, J. Geophys. Res.-Atmos., 110(D16), D16305, doi:10.1029/2004JD005623, 2005.

DeCarlo, P. F., Dunlea, E. J., Kimmel, J. R., Aiken, A. C., Sueper, D., Crounse, J., Wennberg, P. O., Emmons, L., Shinozuka, Y., Clarke, A., Zhou, J., Tomlinson, J., Collins, D. R., Knapp, D., Weinheimer, A. J., Montzka, D. D., Campos, T., and Jimenez, J. L.: Fast airborne aerosol size and chemistry measurements above Mexico City and Central Mexico during the MILAGRO campaign, Atmos. Chem. Phys., 8, 4027-4048, 2008, http://www.atmos-chem-phys.net/8/4027/2008/.

DeCarlo, P. F., Kimmel, J. R., Trimborn, A., Northway, M. J., Jayne, J. T., Aiken, A. C., Gonin, M., Fuhrer, K., Horvath, T., Docherty, K. S., Worsnop, D. R., and Jimenez, J. L.: Field-deployable, high-resolution, time-of-flight aerosol mass spectrometer, Anal. Chem., 78(24), 8281-8289, 2006.

Dickerson, R. R., Li, C., Li, Z., Marufu, L. T., Stehr, J. W., McClure, B., Krotkov, N., Chen, H., Wang, P., Xia, X., Ban, X., Gong, F., Yuan, J., and Yang, J.: Aircraft observations of dust and pollutants over northeast China: Insight into the meteorological mechanisms of transport, J. Geophys. Res., 112, D24S90, doi:10.1029/2007JD008999, 2007.
Docherty, K. S., Stone, E. A., Ulbrich, I. M., DeCarlo, P. F., Snyder, D. C., Schauer, J. J., Peltier, R. E., Weber, R. J., Murphy, S. M., Seinfeld, J. H., Grover, B. D., Eatough, D. J., and Jimenez, J. L.: Apportionment of Primary and Secondary Organic Aerosols in Southern California during the 2005 Study of Organic Aerosols in Riverside (SOAR-1), Environ. Sci. Technol., 42(20), 76557662, doi:10.1021/es8008166, 2008.

Duce, R. A., Unni, C. K., Ray, B. J., Prospero, J. M., and Merrill, J. T.: Long-range atmospheric transport of soil dust from Asia to the tropical North Pacific - temporal variability, Science, 209, 1522-1524, 1980.

Emmons, L. K., Walters, S., Hess, P. G., Lamarque, J.-F., Pfister, G. G., Fillmore, D., Granier, C., Guenther, A., Kinnison, D., Laepple, T., Orlando, J., Tie, X., Tyndall, G., Wiedinmyer, C., Baughcum, S. L., and Kloster, S.: Description and evaluation of the Model for Ozone and Related chemical Tracers, version 4 (MOZART-4), Geosci. Model Dev. Discuss., 2, $1157-$ 1213, 2009.

Feingold, G. and Kreidenweis, S. M.: Cloud processing of aerosol as modeled by a large eddy simulation with coupled microphysics and aqueous chemistry, J. Geophys. Res., 107(D23), 4687, doi:10.1029/2002JD002054, 2002.

Finlayson-Pitts, B. J. and Pitts, J.N.: Chemistry of the Upper and Lower Atmosphere; Chapter 9, Academic Press: San Diego, California, 2000.

Granier, C. and Mieville, A.: Present and future surface emissions of atmospheric compounds, http://www.aero.jussieu.fr/ projet/ACCENT/POET.php, 2008.

Guenther, A., Karl, T., Harley, P., Wiedinmyer, C., Palmer, P. I., and Geron, C.: Estimates of global terrestrial isoprene emissions using MEGAN (Model of Emissions of Gases and Aerosols from Nature), Atmos. Chem. Phys., 6, 3181-3210, 2006, http://www.atmos-chem-phys.net/6/3181/2006/.

Hadley, O. L., Ramanathan, V., Carmichael, G. R., Tang, Y., Corrigan, C. E., Roberts, G. C., and Mauger, G. S.: Trans-Pacific transport of black carbon and fine aerosols (D<2.5 mm) into North America, J. Geophys. Res., 112, D05309, doi:10.1029/2006JD007632, 2007.

Hand, J. L. and Kreidenweis, S. M.: A New Method for Retrieving Particle Refractive Index and Effective Density from Aerosol Size Distribution Data, Aerosol Sci. Tech., 36(10), 1012-1026, 2002.

Heald, C. L., Goldstein, A. H., Allan, J. D., Aiken, A. C., Apel, E., Atlas, E. L., Baker, A. K., Bates, T. S., Beyersdorf, A. J., Blake, D. R., Campos, T., Coe, H., Crounse, J. D., DeCarlo, P. F., de Gouw, J. A., Dunlea, E. J., Flocke, F. M., Fried, A., Goldan, P., Griffin, R. J., Herndon, S. C., Holloway, J. S., Holzinger, R., Jimenez, J. L., Junkermann, W., Kuster, W. C., Lewis, A. C., Meinardi, S., Millet, D. B., Onasch, T., Polidori, A., Quinn, P. K., Riemer, D. D., Roberts, J. M., Salcedo, D., Sive, B., Swanson, A. L., Talbot, R., Warneke, C., Weber, R. J., Weibring, P., Wennberg, P. O., Worsnop, D. R., Wittig, A. E., Zhang, R., Zheng, J., and Zheng, W.: Total observed organic carbon (TOOC) in the atmosphere: a synthesis of North American observations, Atmos. Chem. Phys., 8, 2007-2025, 2008, http://www.atmos-chem-phys.net/8/2007/2008/.

Heald, C. L., Jacob, D. J., Park, R. J., Alexander, B., Fairlie, T. D., Yantosca, R. M., and Chu, D. A.: Transpacific transport of Asian anthropogenic aerosols and its impact on surface air quality in 
the United States, J. Geophys. Res., 111, D14210, 1-13, 2006.

Heald, C. L., Jacob, D. J., Park, R. J., Russel, L. M., Huebert, B. J., Seinfeld, J. H., Liao, H., and Weber, R. J.: A large organic aerosol source in the free troposphere missing from current models, Geophys. Res. Lett., 32, L18809, doi:10.1029/2005GL023831, 2005.

Heintzenberg, J. and Charlson, R. J.: Design and applications of the integrating nephelometer: A review, J. Atmos. Ocean. Tech., 13, 987-1000, 1996.

Henze, D. K. and Seinfeld, J. H.: Global secondary organic aerosol from isoprene oxidation, Geophys. Res. Lett., 33, L09812, doi:10.1029/2006GL025976, 2006.

Herndon, S. C., Onasch, T. B., Wood, E. C., Kroll, J. H., Canagaratna, M. R., Jayne, J. T., Zavala, M. A., Knighton, W. B., Mazzoleni, C., Dubey, M. K., Ulbrich, I. M., Jimenez, J. L., Seila, R., Gouw, J. A. D., Foy, B. D., Fast, J., Molina, L. T., Kolb, C. E., Worsnop, D. R.: The Correlation of Secondary Organic Aerosol with Odd Oxygen in a Megacity Outflow, Geophys. Res. Lett., 35, L15804, doi:10.1029/2008GL034058, 2008.

Hinds, W. C.:Aerosol Technology: Properties, Behavior, and Measurements of Airborne Particles; Chapter 10, John Wiley \& Sons, Inc., New York, 1999.

Holzer, M. and Hall, T. M.: Low-level transpacific transport, J. Geophys. Res., 112, D09103, 1-11, 2007.

Holzer, M., McKendry, I. G., amd Jaffe, D. A.: Springtime trans-Pacific atmospheric transport from east Asia: A transittime probability density function approach, J. Geophys. Res., 108(D22), 4708, doi:10.1029/2003JD003558, 2003.

Hoppel, W. A., Frick, G. M., and Larson, R. E.: Effect of nonprecipitating clouds on the aerosol size distribution in the marine boundary layer, Geophys. Res. Lett., 13(1), 125-128, 1986.

Horowitz, L. W., Walters, S., Mauzerall, D. L., Emmons, L. K., Rasch, P. J., Granier, C., Tie, X., Lamarque, J.-F., Schultz, M. G., Tyndall, G. S., Orlando, J. J., and Brasseur, G. P.: A global simulation of tropospheric ozone and related tracers: Description and evaluation of MOZART, version 2, J. Geophys. Res., 108, 4784, doi:10.1029/2002JD002853, 2003.

Huebert, B., Bertram, T., Kline, J., Howell, S., Eatough, D., and Blomquist, B.: Measurements of organic and elemental carbon in Asian outflow during ACE-Asia from the NSF/NCAR C-130, J. Geophys. Res., 109, D19S11, 1-16, 2004.

Huffman, J. A., Docherty, K. S., Aiken, A. C., Cubison, M. J., Ulbrich, I. M., DeCarlo, P. F., Sueper, D., Jayne, J. T., Worsnop, D. R., Ziemann, P. J., and Jimenez, J. L.: Chemically-resolved aerosol volatility measurements from two megacity field studies, Atmos. Chem. Phys. Discuss., 9, 2645-2697, 2009, http://www.atmos-chem-phys-discuss.net/9/2645/2009/.

Huffman, J. A., Ziemann, P. J., Jayne, J. T., Worsnop, D. R., and Jimenez, J. L.: Development and Characterization of a Fast-Stepping/Scanning Thermodenuder for ChemicallyResolved Aerosol Volatility Measurements, Aerosol Sci. Tech., 42, 395-407, 2008.

Husar, R. B., Tratt, D. M., Schichtel, B. A., Falke, S. R., Li, F., Jaffe, D., Gasso, S., Gill, T., Laulainen, N. S., Lu, F., Reheis, M. C., Chun, Y., Westphal, D., Holben, B. N., Gueymard, C., McKendry, I., Kuring, N., Feldman, G. C., McClain, C., Frouin, R. J., Merrill, J., DuBois, D., Vignola, F., Murayama, T., Nickovic, S., Wilson, W. E., Sassen, K., Sugimoto, N., and Malm, W. C.: Asian dust events of April 1998, J. Geophys. Res., 106,
18317-18330, 2001.

Igarashi, Y., Sawa, Y., Yoshioka, K., Takahashi, H., Matsueda, H., and Dokiya, Y.: Seasonal variations in $\mathrm{SO}_{2}$ plume transport over Japan: Observations at the summit of Mt. Fuji from winter to summer, Atmos. Environ., 40, 7018-7033, 2006.

IPCC:Intergovernmental Panel on Climate Change, Climate Change 2007: The Scientific Basis, Cambridge University Press, Cambridge, England, 2007.

Jacob, D. J., Logan, J. A., and Murti, P. P.: Effect of rising Asian emissions on surface ozone in the United States, Geophys. Res. Lett., 26, 2175-2178, 1999.

Jaeglé, L.: Atmospheric Science: Pumping Up Surface Air, Science, 315, 772-773, 2007.

Jaeglé, L., Jaffe, D., Price, H. U., Weiss-Penzias, P., Palmer, P. I., Evans, M. J., Jacob, D. J., and Bey, I.: Sources and budgets for $\mathrm{CO}$ and $\mathrm{O}_{3}$ in the northeastern Pacific during the spring of 2001: Results from the PHOBEA-II Experiment, J. Geophys. Res., 108(D20), 8802, doi:10.1029/2002JD003121, 2003.

Jaffe, D., Anderson, T., Covert, D., Kotchenruther, R., Trost, B., Danielson, J., Simpson, W., Berntsen, T., Karlsdottir, S., Blake, D., Harris, J., Carmichael, G., and Uno, I.: Transport of Asian air pollution to North America, Geophys. Res. Lett., 26(6), 711714, 1999.

Jaffe, D., McKendry, I., Anderson, T., Price, H.: Six “new” episodes of trans-Pacific transport of air pollutants, Atmos. Environ., 37, 391-404, 2003.

Jaffe, D., Tamura, S., and Harris, J.: Seasonal cycle and composition of background fine particles along the west coast of the US, Atmos. Environ., 39, 297-306, 2005.

Jayne, J. T., Leard, D. C., Zhang, X. F., Davidovits, P., Smith, K. A., Kolb, C. E., and Worsnop, D. R.: Development of an aerosol mass spectrometer for size and composition analysis of submicron particles, Aerosol Sci. Tech., 33(1-2), 49-70, 2000.

Jimenez, J. L., Jayne, J. T., Shi, Q., Kolb, C. E., Worsnop, D. R., Yourshaw, I., Seinfeld, J. H., Flagan, R. C., Zhang, X., Smith, K. A., Morris, J., and Davidovits, P.: Ambient Aerosol Sampling Using the Aerodyne Aerosol Mass Spectrometer, J. Geophys. Res., 108(D7), 8425, doi:10.1029/2001JD001213, 2003.

Kaku, K. C., Hegg, D. A., Covert, D. S., Santarpia, J. L., Jonsson, H., Buzorius, G., and Collins, D. R.: Organics in the Northeastern Pacific and their impacts on aerosol hygroscopicity in the subsaturated and supersaturated regimes, Atmos. Chem. Phys., 6, 4101-4115, 2006, http://www.atmos-chem-phys.net/6/4101/2006/.

Kaneyasu, N., Ohta, S., and Murao, N.: Seasonal variation in the chemical composition of atmospheric aerosols and gaseous species in Sapporo, Japan, Atmos. Environ., 29(13), 1559-1568, 1995.

Keating, T. J., West, J. J., and Jaffe, D. A.: Air Quality Impacts of Intercontinental Transport, EM, 28-30, 2005.

Kim, H. S., Tans, P. P., and Novelli, P. C.: On the regional background levels of carbon monoxide observed in East Asia during 1991-2004, Air Quality, Atmosphere and Health, 1, 37-44, doi:10.1007/s11869-008-0001-3, 2008.

Kleinman, L. I., Daum, P. H., Lee, Y.-N., Senum, G. I., Springston, S. R., Wang, J., Berkowitz, C., Hubbe, J., Zaveri, R. A., Brechte, F. J., Jayne, J., Onasch, T. B., and Worsnop, D.: Aircraft observations of aerosol composition and ageing in New England and Mid-Atlantic States during the summer 2002 New England Air 
Quality Study field campaign, J. Geophys. Res., 112, D09310, doi:10.1029/2006JD007786, 2007.

Kleinman, L. I., Springston, S. R., Daum, P. H., Lee, Y.-N., Nunnermacker, L. J., Senum, G. I., Wang, J., Weinstein-Lloyd, J., Alexander, M. L., Hubbe, J., Ortega, J., Canagaratna, M. R., and Jayne, J.: The time evolution of aerosol composition over the Mexico City plateau, Atmos. Chem. Phys., 8, 1559-1575, 2008, http://www.atmos-chem-phys.net/8/1559/2008/.

Kuhns, H., Knipping, E. M., and Vukovich, J. M.: Development of a United States-Mexico emissions inventory for the Big Bend Regional Aerosol and Visibility Observational (BRAVO) Study, J. Air Waste Manage., 55, 677-692, 2005.

Lamarque, J.-F., Kiehl, J. T., Hess, P. G., Collins, W. D., Emmons, L. K., Ginoux, P., Luo, C., and Tie, X. X.: Response of a coupled chemistry-climate model to changes in aerosol emissions: Global impact on the hydrological cycle and the tropospheric burdens of OH, ozone and NOx, Geophys. Res. Lett., 32, L16809, doi:10.1029/2005GL023419, 2005.

Leaitch, W. R., Macdonald, A. M., Anlauf, K. G., Liu, P. S. K., Toom-Sauntry, D., Li, S.-M., Liggio, J., Hayden, K., Wasey, M. A., Russell, L. M., Takahama, S., Liu, S., van Donkelaar, A., Duck, T., Martin, R. V., Zhang, Q., Sun, Y., McKendry, I., Shantz, N. C., and Cubison, M.: Evidence for Asian dust effects from aerosol plume measurements during INTEX-B 2006 near Whistler, BC, Atmos. Chem. Phys., 9, 3523-3546, 2009, http://www.atmos-chem-phys.net/9/3523/2009/.

Liang, Q., Jaegle, L., Hudman, R. C., Turquety, S., Jacob, D. J., Avery, M. A., Browell, E. V., Sachse, G. W., Blake, D. R., Brune, W., Ren, X., Cohen, R. C., Dibb, J. E., Fried, A., Fuelberg, H., Porter, M., Heikes, B. G., Huey, G., Singh, H. B., and Wennberg, P. O.: Summertime influence of Asian pollution in the free troposphere over North America, J. Geophys. Res., 112, D12S11, doi:10.1029/2006JD007919, 2007.

Liang, Q., Jaegle, L., Jaffe, D. A., Weiss-Penzias, P., Heckman, A., and Snow, J. A.: Long-range transport of Asian pollution to the northeast Pacific: Seasonal variations and transport pathways of carbon monoxide, J. Geophys. Res., 109, D23S07, doi:10.1029/2003JD004402, 2004.

Liao, H., Henze, D. K., Seinfeld, J. H., Wu, S. L., and Mickley, L. J.: Biogenic secondary organic aerosol over the United States: Comparison of climatological simulations with observations, J. Geophys. Res., 112, D06201, doi:10.1029/2006JD007813, 2007.

Lide, D. R. and Kehiaian, H. V.: CRC Handbook of Thermophysical and Thermochemical Data, CRC Press, New York, NY, 2007.

Lim, H.-J., Turpin, B. J., Russell, L., and Bates, T. S.: Organic and elemental carbon measurements during ACE-Asia suggest a longer atmospheric lifetime for elemental carbon, Environ. Sci. Technol., 37, 3055-3061, doi:10.1021/es020988s, 2003.

Liu, H. Y., Jacob, D. J., Bey, I., and Yantosca, R. M.: Constraints from $\mathrm{Pb}-210$ and $\mathrm{Be}-7$ on wet deposition and transport in a global three-dimensional chemical tracer model driven by assimilated meteorological fields, J. Geophys. Res., 106, 12109_ 12128, 2001.

Liu, J. and Mauzerall, D. L.: Potential influence of inter-continental transport of sulfate aerosols on air quality, Environ. Res. Lett., 2, 045029, doi:10.1088/1748-9326/2/4/045029, 2007.

Liu, J., Mauzerall, D. L., and Horowitz, L. W.: Source-receptor relationships between East Asian sulfur dioxide emissions and Northern Hemisphere sulfate concentrations, Atmos. Chem.
Phys., 8, 3721-3733, 2008,

http://www.atmos-chem-phys.net/8/3721/2008/.

Mari, C., Jacob, D. J., and Bechtold, P.: Transport and scavenging of soluble gases in a deep convective cloud, J. Geophys. Res., 105, 22255-22267, 2000.

Maring, H., Savoie, D. L., Izaguirre, M. A., Custals, L., and Reid, J. S.: Mineral dust aerosol size distribution change during atmospheric transport, J. Geophys. Res., 108(D19), 8592, doi:8510.1029/2002JD002536, 2003.

Massling, A., Leinert, S., Wiedensohler, A., and Covert, D.: Hygroscopic growth of sub-micrometer and one-micrometer aerosol particles measured during ACE-Asia, Atmos. Chem. Phys., 7, 3249-3259, 2007,

http://www.atmos-chem-phys.net/7/3249/2007/.

McKendry, I. G., Hacker, J. P., Stull, R., Sakiyama, S., Mignacca, D., and Reid, K.: Long-range transport of Asian dust to the Lower Fraser Valley, British Columbia, Canada, J. Geophys. Res., 106(D16), 18361-18370, 2001

McNaughton, C. S., Clarke, A. D., Howell II, S. G., Brekhovskikh, V., Weber, R. J., Orsini, D. A., Covert, D. S., Buzorius, G., Brechtel, F. J., Carmichael, G. R., Tang, Y., Eisele, F. L., Mauldin, R. L., Bandy, A. R., Thornton, D. C., and Blomquist, B.: Spatial distribution and size evolution of particles in Asian outflow: Significance of primary and secondary aerosols during ACE-Asia and TRACE-P, J. Geophys. Res., 109, D19S06, doi:10.1029/2003JD003528, 2004.

McNaughton, C. S., Clarke, A. D., Kapustin, V., Shinozuka, Y., Howell, S. G., Anderson, B. E., Winstead, E., Dibb, J., Scheuer, E., Cohen, R. C., Wooldridge, P., Perring, A., Huey, L. G., Kim, S., Jimenez, J. L., Dunlea, E. J., DeCarlo, P. F., Wennberg, P. O., Crounse, J. D., Weinheimer, A. J., and Flocke, F.: Observations of heterogeneous reactions between Asian pollution and mineral dust over the Eastern North Pacific during INTEX-B, Atmos. Chem. Phys. Discuss., 9, 8469-8539, 2009, http://www.atmos-chem-phys-discuss.net/9/8469/2009/.

Miyakawa, T., Takegawa, N., and Kondo, Y.: Removal of sulfur dioxide and formation of sulfate aerosol in Tokyo, J. Geophys. Res., 112, D13209, doi:10.1029/2006JD007896, 2007.

Miyazaki, Y., Kondo, Y., Han, S., Koike, M., Kodama, D., Komazaki, Y., Tanimoto, H., and Matsueda, H.: Chemical characteristics of water-soluble organic carbon in the Asian outflow, J. Geophys. Res., 112, D22S30, doi:10.1029/2007JD009116, 2007.

Molina, L. T., Madronich, S., and Gaffney, J. S.: An Overview of the MILAGRO Campaign: Mexico City Emissions and Their Evolution, in preparation for Atm. Chem. Phys., 2009.

Molina, M. J., Ivanov, A. V., Trakhtenberg, S., and Molina, L. T. Atmospheric evolution of organic aerosol, Geophys. Res. Lett. 31, L22104, doi:10.1029/2004GL020910, 2004.

Montzka, S. A., Butler, J. H., Hall, B. D., Mondeel, D. J., and Elkins, J. W.: A decline in tropospheric organic bromine, Geophys. Res. Lett., 30(15), 1826, doi:10.1029/2003GL017745, 2003.

Murphy, D. M., Cziczo, D. J., Froyd, K. D., Hudson, P. K., Matthew, B. M., Middlebrook, A. M., Peltier, R. E., Sullivan, A., Thomson, D. S., and Weber, R. J.: Single-particle mass spectrometry of tropospheric aerosol particles, J. Geophys. Res., 111, D23S32, 1-15, 2006.

Murphy, D. M. C., Hudson, P. K., and Thomson, D. S.: Car- 
bonaceous material in aerosol particles in the lower stratosphere and tropopause region, J. Geophys. Res., 112, D04203, doi:10.1029/2006JD007297, 2007.

Nowak, J. B., Parrish, D. D., Neuman, J. A., Holloway, J. S., Cooper, O. R., Ryerson Jr., T. B., Flocke, F., Roberts, J. M., Atlas, E., Gouw, J. A. D., Donnelly, S., Dunlea, E., Hübler, G., Huey, L. G., Schauffler, S., Tanner, D. J., Warneke, C., and Fehsenfeld, F. C.: Gas-phase chemical characteristics of Asian emission plumes observed during ITCT 2K2 over the eastern North Pacific Ocean, J. Geophys. Res., 109, D23S19, doi:10.1029/2003JD004488, 2004.

O'Dowd, C. D., Facchini, M. C., Cavalli, F., Ceburnis, D., Mircea, M., Decesari, S., Fuzzi, S., Yoon, Y. J., and Putaud, J. P.: Biogenically-driven organic contribution to marine aerosol, Nature, 431, 676-680, doi:10.1038/nature02959, 2004.

Ohara, T., Akimoto, H., Kurokawa, J., Horii, N., Yamaji, K., Yan, X., and Hayasaka, T.: An Asian emission inventory of anthropogenic emission sources for the period 1980-2020, Atmos. Chem. Phys., 7, 4419-4444, 2007,

http://www.atmos-chem-phys.net/7/4419/2007/.

Ooki, A., Uematsu, M., and Noriki, S.: Size-resolved sulfate and ammonium measurements in marine boundary layer over the North and South Pacific, Atmos. Environ., 41, 81-91, 2007.

Park, K., Kittelson, D. B., Zachariah, M. R., and McMurry, P. H.: Measurement of Inherent Material Density of Nanoparticle Agglomerates, J. Nanopart. Res., 6, 267-272, 2004a.

Park, R. J., Jacob, D. J., Chin, M., and Martin, R. V.: Sources of carbonaceous aerosols over the United States and implications for natural visibility, J. Geophys. Res., 108, 4355, doi:10.1029/2002JD003190, 2003.

Park, R. J., Jacob, D. J., Field, B. D., Yantosca, R. M., and Chin, M.: Natural and Transboundary Pollution Influences on SulfateNitrate-Ammonium Aerosols in the United States: Implications for Policy, J. Geophys Res., 109(D24), 15204-15220, 2004b.

Park, R. J., Jacob, D. J., Kumar, N., and Yantosca, R. M.: Regional visibility statistics in the United States: Natural and transboundary pollution influences, and implications for the Regional Haze Rule, Atmos. Environ., 40, 5405-5423, 2006.

Park, R. J., Jacob, D. J., Palmer, P. I., Clarke, A. D., Weber, R. J., Zondlo, M. A., Eisele, F. L., Bandy, A. R., Thornton, D. C., Sachse, G. W., and Bond, T. C.: Export efficiency of black carbon aerosol in continental outflow: Global implications, J. Geophys. Res., 110, D11205, doi:10.1029/2004JD005432, 2005.

Parrish, D. D., Dunlea, E. J., Atlas, E. L., Schauffler, S., Donnelly, S., Stroud, V., Goldstein, A. H., Millet, D. B., McKay, M., Jaffe, D. A., Price, H. U., Hess, P. G., Flocke, F., and Roberts, J. M.: Changes in the photochemical environment of the temperate North Pacific troposphere in response to increased Asian emissions, J. Geophys Res., 109, D23S18, doi:10.1029/2004JD004978, 2004.

Parrish, D. D., Hahn, C. J., Williams, E. J., Norton, R. B., Fehsenfeld, F. C., Singh, H. B., Shetter, J. D., Gandrud, B. W., and Ridley, B. A.: Indications of photochemical histories of Pacific air masses from measurements of atmospheric trace species at Point Arena, California, J. Geophys. Res., 97(D14), 15883-15901, 1992.

Peltier, R. E., Hecobian, A. H., Weber, R. J., Stohl, A., Atlas, E. L., Riemer, D. D., Blake, D. R., Apel, E., Campos, T., and Karl, T.: Investigating the sources and atmospheric processing of fine particles from Asia and the Northwestern United States measured during INTEX B, Atmos. Chem. Phys., 8, 1835-1853, 2008, http://www.atmos-chem-phys.net/8/1835/2008/.

Pfister, G., Emmons, L. K., Hess, P. G., Lamarque, J.-F., Walters, S., Guenther, A., Palmer, P. I., and Lawrence, P.: Contribution of isoprene to chemical budgets: A model tracer study with the NCAR CTM MOZART-4, J. Geophys. Res., 113, D05308, doi:10.1029/2007JD008948, 2008.

Pfister, G. G., Emmons, L. K., Edwards, D. P., Arellano, A., Sachse, G., and Campos, T.: Transpacific pollution transport during INTEX-B: spring 2006 in context to previous years, Atmos. Chem. Phys. Discuss., 9, 17817-17849, 2009,

http://www.atmos-chem-phys-discuss.net/9/17817/2009/.

Pope, C. A., Burnett, R. T., Thun, M. J., Calle, E. E., Krewski, D., Ito, K., and Thurston, G. D.: Lung Cancer, Cardiopulmonary Mortality, and Long-term Exposure to Fine Particulate Air Pollution, J. Amer. Med. Assoc., 287(9), 1132-1141, 2002.

Pope, C. A. I.: Review: Epidemiological Basis for Particulate Air Pollution Health Standards, Aerosol Sci. Tech., 32, 4-14, 2000.

Prospero, J. M., Savoie, D. L., and Arimoto, R.: Long-term record of nss-sulfate and nitrate in aerosols on Midway Island, 1981-2000: Evidence of increased (now decreasing?) anthropogenic emissions from Asia, J. Geophys. Res., 108(D1), 4019, doi:10.1029/2001JD001524, 2003.

Quinn, P. K., Bates, T. S., Coffman, D., Onasch, T. B., Worsnop, D., Baynard, T., Gouw, J. A. D., Goldan, P. D., Kuster, W. C., Williams, E., Roberts, J. M., Lerner, B., Stohl, A., Pettersson, A., and Lovejoy, E. R.: Impacts of sources and aging on submicrometer aerosol properties in the marine boundary layer across the Gulf of Maine, J. Geophys. Res., 111, D23S36, doi:10.1029/2006JD007582, 2006.

Reidmiller, D. R., Jaffe, D. A., Chand, D., Strode, S., Swartzendruber, P., Wolfe, G. M., and Thornton, J. A.: Interannual variability of long-range transport as seen at the Mt. Bachelor observatory, Atmos. Chem. Phys., 9, 557-572, 2009, http://www.atmos-chem-phys.net/9/557/2009/.

Ridley, B., Ott, L., Pickering, K., Emmons, L., Montzka, D., Weinheimer, A., Knapp, D., Grahek, F., Li, L., Heymsfield, G., McGill, M., Kucera, P., Mahoney, M. J., Baumgardner, D., Schultz, M., and Brasseur, G.: Florida thunderstorms: A faucet of reactive nitrogen to the upper troposphere, J. Geophys. Res., 109, D17305, doi:10.1029/2004JD004769, 2004.

Roberts, G., Mauger, G., Hadley, O., and Ramanathan, V.: North American and Asian aerosols over the eastern Pacific Ocean and their role in regulating cloud condensation nuclei, J. Geophys. Res., 111, D13205, doi:10.1029/2005JD006661, 2006.

Sander, S. P., Orkin, V. L., Kurylo, M. J., Golden, D. M., Huie, R. E., Kolb, C. E., Finlayson-Pitts, B. J., Molina, M. J., Friedl, R. R., Ravishankara, A. R., Moortgat, G. K., Keller-Rudek, H., and Wine, P. H.:Chemical Kinetics and Photochemical Data for Use in Atmospheric Studies, JPL Publication 06-2, 2006.

Schauer, J. J., Rogge, W. F., Hildemann, L. M., Mazurek, M. A., and Cass, G. R.: Source apportionment of airborne particulate matter using organic compounds as tracers, Atmos. Environ., 30(22), 3837-3855, 1996.

Schindler, D.: From acid rain to toxic snow, Ambio, 28(4), 350355, 1999.

Schindler, D. W.: Effects of Acid-Rain on Fresh-Water Ecosystems, Science, 239, 4836, 149-157, 1988. 
Schwartz, J.: Air-Pollution and Daily Mortality - a Review and Meta Analysis, Environ. Res., 64(1), 36-52, 1994.

Singh, H. B., Brune, W. H., Crawford, J. H., Flocke, F., and Jacob, D. J.: Chemistry and transport of pollution over the Gulf of Mexico and the Pacific: spring 2006 INTEX-B campaign overview and first results, Atmos. Chem. Phys., 9, 2301-2318, 2009, http://www.atmos-chem-phys.net/9/2301/2009/.

Snow, J. A., Heikes, B. G., Shen, H., O'Sullivan, D. W., Fried, A., and Walega, J.: Hydrogen peroxide, methyl hydroperoxide, and formaldehyde over North America and the North Atlantic, J. Geophys. Res., 112, D12S07, doi:10.1029/2006JD007746, 2007.

Solomon, S.: Stratospheric Ozone Depletion: A Review of Concepts and History, Rev. Geophys., 37, 275-316, 1999.

Spracklen, D. V., Arnold, S. R., Sciare, J., Carslaw, K. S., Pio, C.: Globally significant oceanic source of organic carbon aerosol, J. Geophys. Res., 35, L12811, doi:10.1029/2008GL033359, 2008.

Stohl, A., Eckhardt, S., Forster, C., James, P., and Spichtinger, N.: On the pathways and timescales of intercontinental air pollution transport, J. Geophys Res., 107(D23), 4684, doi:10.1029/2001JD001396, 2002.

Strode, S. A., Jaegle, L., Jaffe, D. A., Swartzendruber, P. C., Selin, N. E., Holmes, C., and Yantosca, R. M.: TransPacific transport of mercury, J. Geophys. Res., 113, D15305, doi:10.1029/2007JD009428, 2008.

Sun, Y., Zhang, Q., Macdonald, A. M., Hayden, K., Li, S. M., Liggio, J., Liu, P. S. K., Anlauf, K. G., Leaitch, W. R., Steffen, A., Cubison, M., Worsnop, D. R., van Donkelaar, A., and Martin, R. V.: Size-resolved aerosol chemistry on Whistler Mountain, Canada with a high-resolution aerosol mass spectrometer during INTEX-B, Atmos. Chem. Phys., 9, 3095-3111, 2009, http://www.atmos-chem-phys.net/9/3095/2009/.

Takami, A., Miyoshi, T., Shimono, A., and Hatakeyama, S.: Chemical composition of fine aerosol measured by AMS at Fukue Island, Japan during APEX period, Atmos. Environ., 39, 49134924, 2005.

Takami, A., Miyoshi, T., Shimono, A., Kaneyasu, N., Kato, S., Kajii, Y., and Hatakeyama, S.: Transport of anthropogenic aerosols from Asia and subsequent chemical transformation, J. Geophys. Res., 112, D22S31, 1-11, 2007.

Takegawa, N., Miyakawa, T., Kondo, Y., Blake, D. R., Kanaya, Y., Koike, M., Fukuda, M., Komazaki, Y., Miyazaki, Y., Shimono, A., and Takeuchi, T.: Evolution of submicron organic aerosol in polluted air exported from Tokyo, Geophys. Res. Lett., 33, L15814, 1-5, 2006a.

Takegawa, N., Miyakawa, T., Kondo, Y., Jimenez, J. L., Zhang, Q., Worsnop, D. R., and Fukuda, M.: Seasonal and diurnal variations of submicron organic aerosol in Tokyo observed using the Aerodyne aerosol mass spectrometer, J. Geophys. Res.-Atmos., 111(D11), 17, 2006b.

Takegawa, N., Miyazaki, Y., Kondo, Y., Komazaki, Y., Miyakawa, T., Jimenez, J. L., Jayne, J. T., Worsnop, D. R., Allan, J. D., and Weber, R. J.: Characterization of an Aerodyne Aerosol Mass Spectrometer (AMS): Intercomparison with other aerosol instruments, Aerosol Sci. Tech., 39(8), 760-770, 2005.

Takiguchi, Y., Takami, A., Sadanaga, Y., Lun, X., Shimizu, A., Matsui, I., Sugimoto, N., Wang, W., Bandow, H., and Hatakeyama, S.: Transport and transformation of total reactive nitrogen over the East China Sea, J. Geophys. Res., 113, D10306,
doi:10.1029/2007JD009462, 2008.

Tang, Y., Carmichael, G. R., Horowitz, L. W., Uno, I., Woo, J.H., Streets, D. G., Dabdub, D., Kurata, G., Sandu, A., Allan, J., Atlas, E., Flocke, F., Huey, L. G., Jakoubek, R. O., Millet, D. B., Quinn, P. K., Worsnop, J. M. R. D. R., Goldstein, A., Donnelly, T., Schauffler, S., Stroud, V., Johnson, K., Avery, M. A., Singh, H. B., and Apel, E. C.: Multiscale simulations of tropospheric chemistry in the eastern Pacific and on the US West Coast during spring 2002, J. Geophys. Res.-Atmos., 109, D23S11, doi:10.1029/2004JD004513, 2004a.

Tang, Y., Carmichael, G. R., Seinfeld, J. H., Dabdub, D., Weber, R. J., Huebert, B., Clarke, A. D., Guazzotti, S. A., Sodeman, D. A., Prather, K. A., Uno, I., Woo, J.-H., Yienger, J. J., Streets, D. G., Quinn, P. K., Johnson, J. E., Chul-Han, S., Grassian, V. H., Sandu, A., Talbot, R. W., and Dibb, J. E.: Three-dimensional simulations of inorganic aerosol distributions in east Asia during spring 2001, J. Geophys. Res., 109, D19S23, doi:10.1029/2003JD004201, 2004b.

Thulasiraman, S., O’Neill, N. T., Royer, A., Holben, B. N., Westphal, D. L., McArthur, L. J. B.: Sunphotometric observations of the 2001 Asian dust storm over Canada and the US, Geophys. Res. Lett., 29(8), 1255, doi:10.1029/2001GL014188, 2002.

Topping, D., Coe, H., McFiggans, G., Burgess, R., Allan, J., Alfarra, M. R., Bower, K., Choularton, T. W., Decesari, S., and Facchini, M. C.: Aerosol chemical characteristics from sampling conducted on the Island of Jeju, Korea during ACE Asia, Atmos. Environ., 38, 2111-2123, 2004.

Tu, F. H., Thornton, D. C., Bandy, A. R., Carmichael, G. R., Tang, Y., Thornhill, K. L., Sachse, G. W., and Blake, D. R.: Long-range transport of sulfur dioxide in the central Pacific, J. Geophys. Res., 109, D15S08, doi:10.1029/2003JD004309, 2004.

Ulbrich, I. M., Canagaratna, M. R., Zhang, Q., Worsnop, D. R., and Jimenez, J. L.: Interpretation of organic components from Positive Matrix Factorization of aerosol mass spectrometric data, Atmos. Chem. Phys., 9, 2891-2918, 2009, http://www.atmos-chem-phys.net/9/2891/2009/.

Uno, I., Yumimoto, K., Shimizu, A., Hara, Y., Sugimoto, N., Wang, Z., Liu, Z., and Winker, D. M.: 3D structure of Asian dust transport revealed by CALIPSO lidar and a 4DVAR dust model, Geophys. Res. Lett., 35, L06803, doi:10.1029/2007GL032329, 2008.

Vaattovaara, P., Huttunen, P. E., Yoon, Y. J., Joutsensaari, J., Lehtinen, K. E. J., O'Dowd, C. D., and Laaksonen, A.: The composition of nucleation and Aitken modes particles during coastal nucleation events: evidence for marine secondary organic contribution, Atmos. Chem. Phys., 6, 4601-4616, 2006, http://www.atmos-chem-phys.net/6/4601/2006/.

van der Werf, G. R., Randerson, J. T., Giglio, L., Collatz, G. J., Kasibhatla, P. S., and Arellano Jr., A. F.: Interannual variability in global biomass burning emissions from 1997 to 2004, Atmos. Chem. Phys., 6, 3423-3441, 2006,

http://www.atmos-chem-phys.net/6/3423/2006/.

van Donkelaar, A., Martin, R. V., Leaitch, W. R., Macdonald, A. M., Walker, T. W., Streets, D. G., Zhang, Q., Dunlea, E. J., Jimenez, J. L., Dibb, J. E., Huey, L. G., Weber, R., and Andreae, M. O.: Analysis of aircraft and satellite measurements from the Intercontinental Chemical Transport Experiment (INTEX-B) to quantify long-range transport of East Asian sulfur to Canada, Atmos. Chem. Phys., 8, 2999-3014, 2008,

http://www.atmos-chem-phys.net/8/2999/2008/. 
VanCuren, R. A.: Asian aerosols in North America: Extracting the chemical composition and mass concentration of the Asian continental aerosol plume from long-term aerosol records in the western United States, J. Geophys. Res., 108(D20), 4623, doi:10.1029/2003JD003459, 2003.

VanCuren, R. A.: Correction to "Asian aerosols in North America: Extracting the chemical composition and mass concentration of the Asian continental aerosol plume from long-term aerosol records in the western United States", J. Geophys. Res., 111, D19206, doi:10.1029/2006JD007653, 2006.

Vaughan, J. K., Claiborn, C., and Finn, D.: April 1998 Asian dust event over the Columbia Plateau, J. Geophys. Res., 106(D16), 18381-18402, 2001.

Wang, G., Kawamura, K., Watanabe, T., Lee, S., Ho, K., and Cao, J.: High loadings and source strengths of organic aerosols in China, Geophys. Res. Lett., 33, L22801, 1-4, 2006.

Wang, S. C. and Flagan, R. C.: Scanning electrical mobility spectrometer, Aerosol Sci. Tech., 13, 230-240, 1990.

Wang, Y. H., Jacob, D. J., Logan, J. A.: Global simulation of tropospheric $\mathrm{O}_{3}-\mathrm{NO}_{\mathrm{x}}$-hydrocarbon chemistry: 1, Model formulation, J. Geophys. Res., 103, 10713-10725, 1998.

Watson, J. G.: Visibility: Science and regulation, J. Air Waste Manage., 52(6), 628-713, 2002.

Weber, R. J., Lee, S., Chen, G., Wang, B., Kapustin, V., Moore, K., Clarke, A. D., Mauldin, L., Kosciuch, E., Cantrell, C., Eisele, F., Thornton, D. C., Bandy, A. R., Sachse, G. W., and Fuelberg, H. E.: New particle formation in anthropogenic plumes advecting from Asia observed during TRACE-P, J. Geophys. Res., 108,(D21), 8814, doi:10.1029/2002JD003112, 2003.

Wesely, M. L.: Parameterization of surface resistances to gaseous dry deposition in regional-scale numerical models, Atmos. Environ., 23, 1293-1304, 1989.

West, B., Wintle, T., Giebel, B., Riemer, D., Apel, E., Hills, A., Emmons, L., Orlando, J., and Sive, B.: MTBE as a Tracer for Asian and Mexican Megacity Emissions, Eos Trans. AGU, Jt. Assem. Suppl., 88(23), A33A-12, 2007.

Wilson, J. C. and Seebaugh, W. R.: Measurement of Aerosol from Aircraft, in: Aerosol Measurement: Principles, Techniques, and Applications, edited by: Baron, P. A. and Willeke, K., WileyInterScience, Inc., 2. edition, 2001.

Wolfe, G. M., Thornton, J. A., McNeill, V. F., Jaffe, D. A., Reidmiller, D., Chand, D., Smith, J., Swartzendruber, P., Flocke, F., and Zheng, W.: Influence of trans-Pacific pollution transport on acyl peroxy nitrate abundances and speciation at Mount Bachelor Observatory during INTEX-B, Atmos. Chem. Phys., 7, 53095325, 2007,

http://www.atmos-chem-phys.net/7/5309/2007/.

Wuebbles, D. J., Lei, H., and Lin, J.: Intercontinental transport of aerosols and photochemical oxidants from Asia and its consequences, Environ. Pollut., 150, 65-84, 2007.

Yienger, J. J., Galanter, M., Holloway, T. A., Phadnis, M. J., Guttikunda, S. K., Carmichael, G. R., Moxim II, W. J.: The episodic nature of air pollution transport from Asia to North America, J. Geophys. Res., 105(D22), 26931-26945, 2000.
Yu, H., Remer, L. A., Chin, M., Bian, H., Kleidman, R. G., and Diehl, T.: A satellite-based assessment of transpacific transport of pollution aerosol, J. Geophys. Res., 113, D14S12, doi:10.1029/2007JD009349, 2008.

Zhang, L., Jacob, D. J., Boersma, K. F., Jaffe, D. A., Olson, J. R., Bowman, K. W., Worden, J. R., Thompson, A. M., Avery, M. A., Cohen, R. C., Dibb, J. E., Flock, F. M., Fuelberg, H. E., Huey, L. G., McMillan, W. W., Singh, H. B., and Weinheimer, A. J.: Transpacific transport of ozone pollution and the effect of recent Asian emission increases on air quality in North America: an integrated analysis using satellite, aircraft, ozonesonde, and surface observations, Atmos. Chem. Phys., 8, 6117-6136, 2008, http://www.atmos-chem-phys.net/8/6117/2008/.

Zhang, Q., Alfarra, M. R., Worsnop, D. R., Allan, J. D., Coe, H., Canagaratna, M. R., and Jimenez, J. L.: Deconvolution and quantification of hydrocarbon-like and oxygenated organic aerosols based on aerosol mass spectrometry, Environ. Sci. Technol., 39(13), 4938-4952, 2005a.

Zhang, Q., Canagaratna, M. R., Jayne, J. T., Worsnop, D. R., and Jimenez, J. L.: Time- and size-resolved chemical composition of submicron particles in Pittsburgh: Implications for aerosol sources and processes, J. Geophys. Res.-Atmos., 110(D7), 19, D07S09, doi:10.1029/2004JD004649, 2005b.

Zhang, Q., Jimenez, J. L., Canagaratna, M. R., Allan, J. D., Coe, H., Ulbrich, I., Alfarra, M. R., Takami, A., Middlebrook, A. M., Sun, Y. L., Dzepina, K., Dunlea, E., Docherty, K., DeCarlo, P. F., Salcedo, D., Onasch, T., Jayne, J. T., Miyoshi, T., Shimono, A., Hatakeyama, S., Takegawa, N., Kondo, Y., Schneider, J., Drewnick, F., Weimer, S., Demerjian, K., Williams, P., Bower, K., Bahreini, R., Cotrell, L., Griffin, R., Rautiainen, J., and Worsnop, D. R.: Ubiquity and Dominance of Oxygenated Species in Organic Aerosols in Anthropogenically-Influenced Northern Hemisphere Mid-latitudes, Geophys. Res. Lett., 34, L13801, doi:10.1029/2007GL029979, 2007.

Zhang, Q., Stanier, C. O., Canagaratna, M. R., Jayne, J. T., Worsnop, D. R., Pandis, S. N., and Jimenez, J. L.: Insights into the chemistry of new particle formation and growth events in Pittsburgh based on aerosol mass spectrometry, Environ. Sci. Technol., 38(18), 4797-4809, 2004.

Zhang, Q., Worsnop, D. R., Canagaratna, M. R., and Jimenez, J. L.: Hydrocarbon-like and oxygenated organic aerosols in Pittsburgh: insights into sources and processes of organic aerosols, Atmos. Chem. Phys., 5, 3289-3311, 2005, http://www.atmos-chem-phys.net/5/3289/2005/.

Zhao, T. L., Gong, S. L., Zhang, X. Y., and Jaffe, D. A.: Asian dust storm influence on North American ambient PM levels: observational evidence and controlling factors, Atmos. Chem. Phys., 8, 2717-2728, 2008, http://www.atmos-chem-phys.net/8/2717/2008/.

Zorn, S. R., Drewnick, F., Schott, M., Hoffmann, T., and Borrmann, S.: Characterization of the South Atlantic marine boundary layer aerosol using an aerodyne aerosol mass spectrometer, Atmos. Chem. Phys., 8, 4711-4728, 2008, http://www.atmos-chem-phys.net/8/4711/2008/. 